\title{
HET CONCEPT VADERSCHAP
}

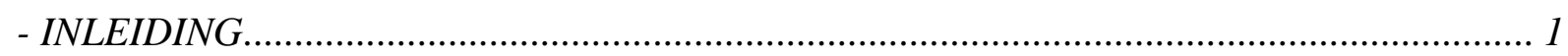

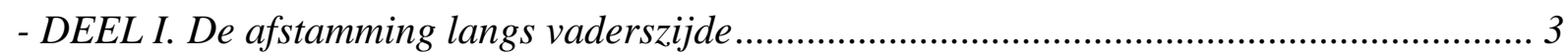

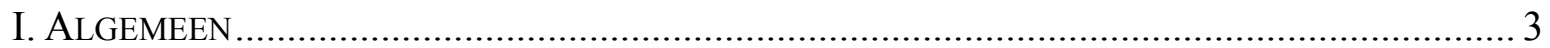

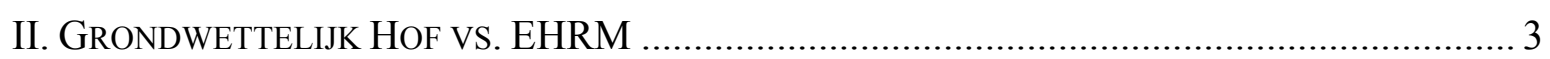

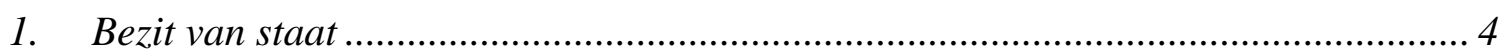

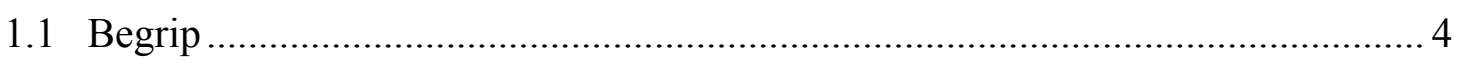

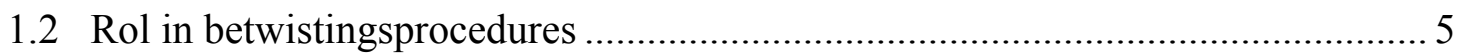

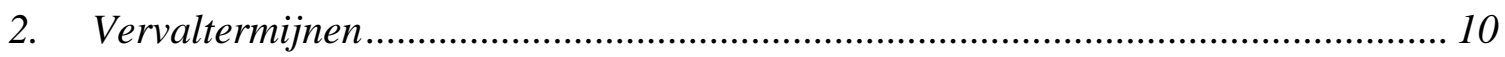

2.1 Betwisting vaderschap van de echtgenoot ..................................................... 10

2.2 Betwisting vaderschap van de erkenner ............................................................. 14

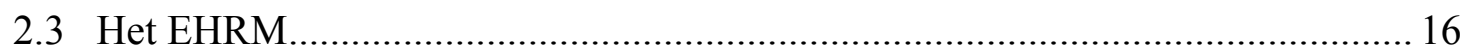

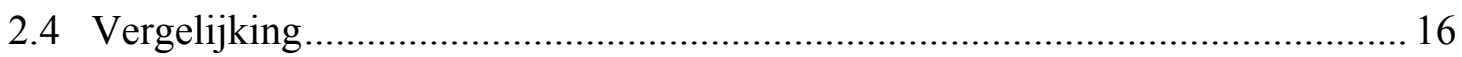

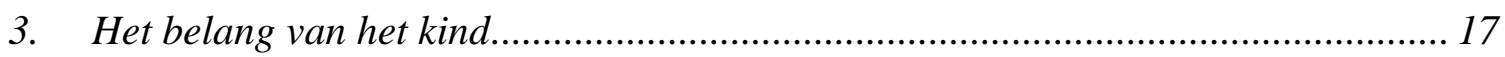

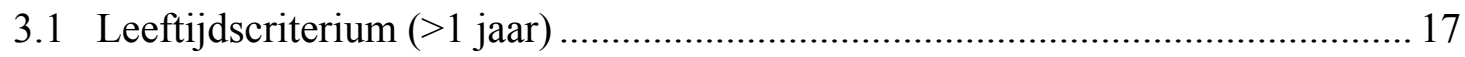

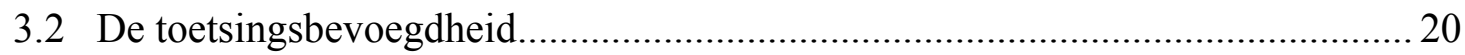

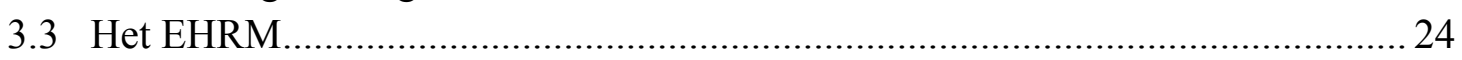

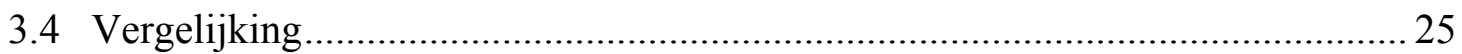

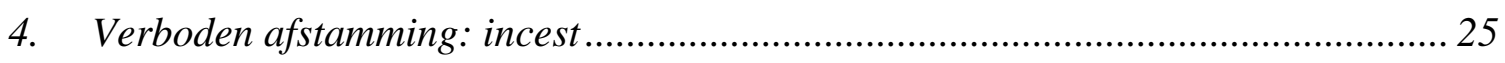

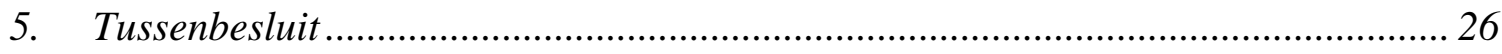

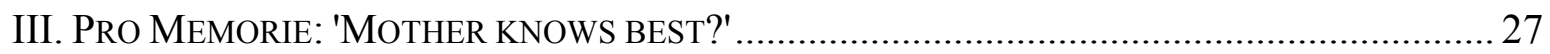

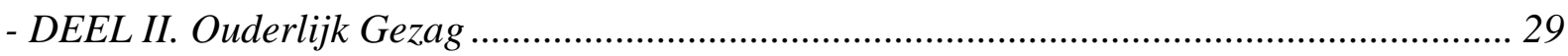

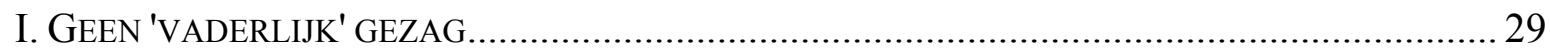

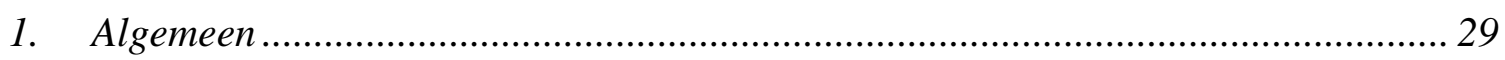

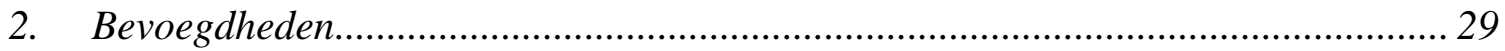

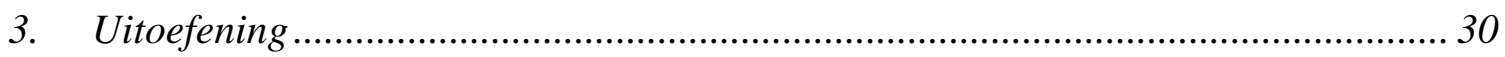

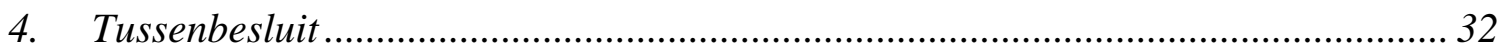

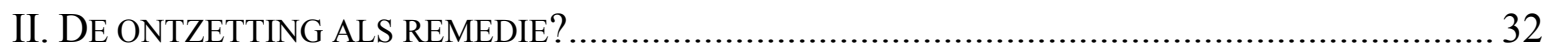

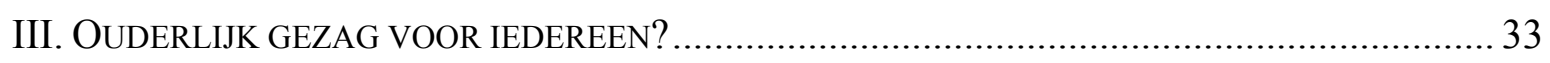

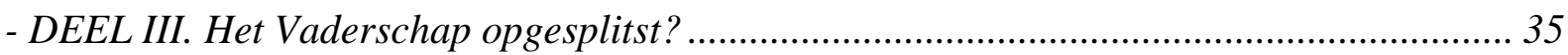

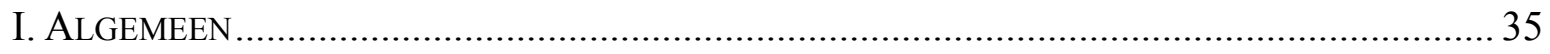

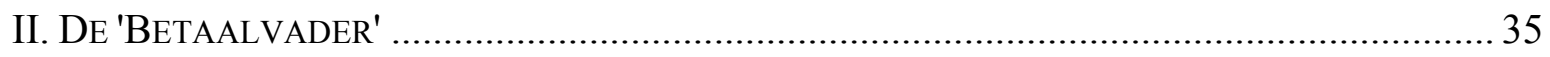

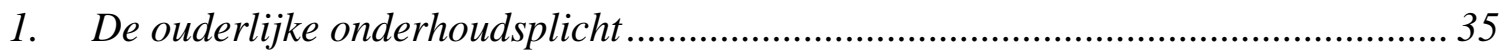

2. De vordering tot levensonderhoud tegen de vermoedelijke verwekker..................... 36

3. De oneigenlijke onderhoudsplicht van de stiefvader ............................................ 37

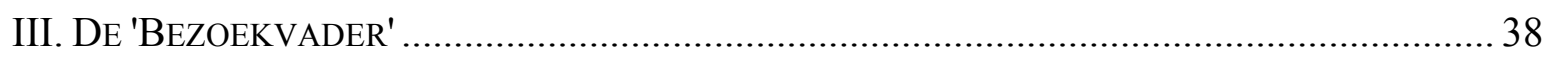

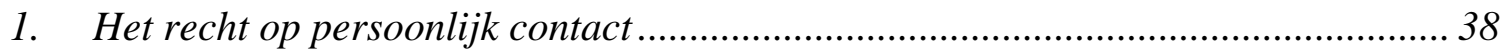

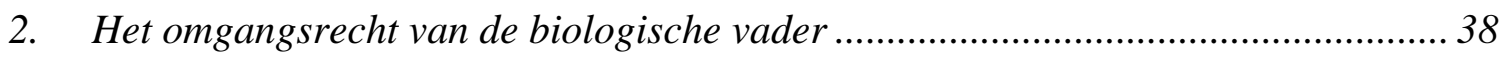

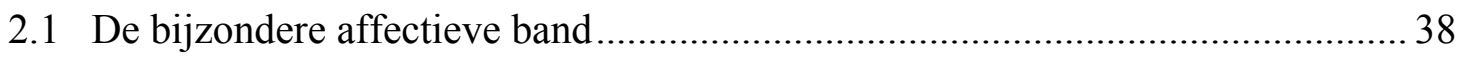

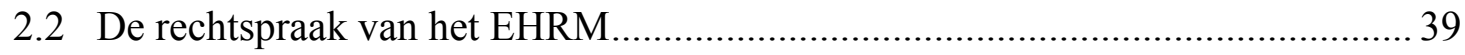

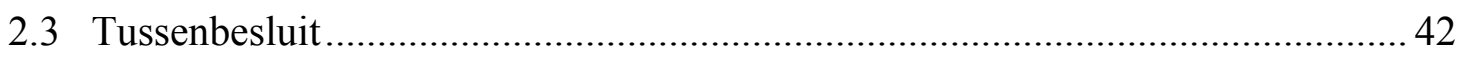




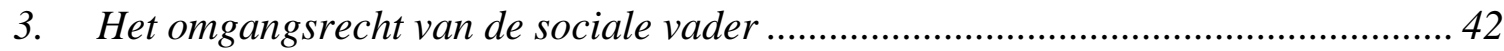

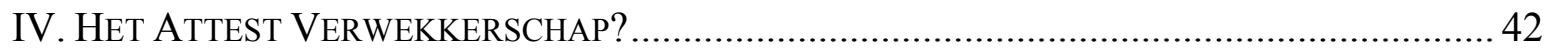

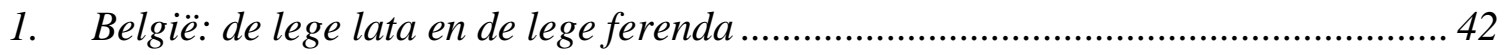

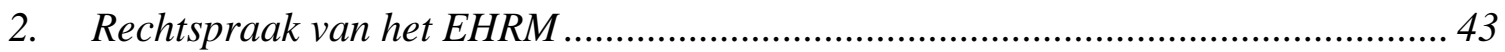

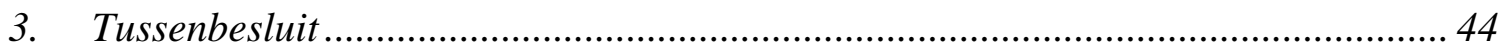

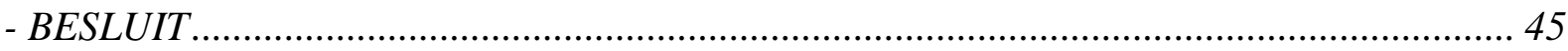

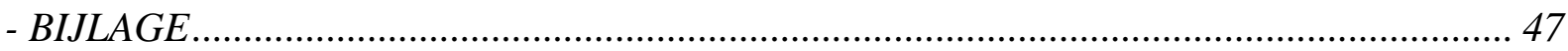

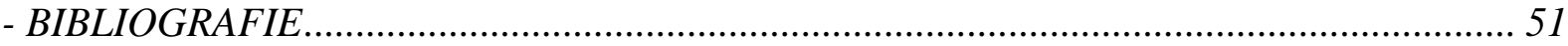

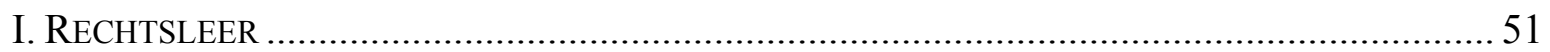

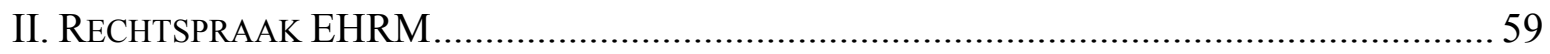

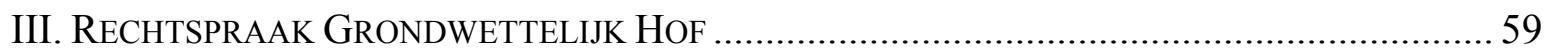




\section{- INLEIDING -}

"Moederschap is een biologische noodzakelijkheid, vaderschap een sociale uitvinding"

- Margaret Mead ${ }^{1}$

Noot van de redactie: De definitieve tekst van deze bijdrage werd ingeleverd op 1 november 2015. Nadien heeft het Belgische Grondwettelijk Hof nog arresten in verband met afstamming geveld en in de loop van 2016 volgt nog een aantal arresten. Deze kunnen worden geconsulteerd via www.const-court.be op trefwoord afstamming.

1.- In Van Dale wordt het begrip 'vader' omschreven als: "man die één of meer kinderen heeft." Wat het "hebben van kinderen" precies betekent, is vatbaar voor interpretatie. Het kan gaan om de man die een kind heeft verwekt, ervoor zorgt, het opvoedt, er mee samenwoont, in zijn levensonderhoud voorziet, beslissingen neemt in diens belang, een relatie heeft met de moeder of er op enige manier emotioneel mee verbonden is. Dit is niet hetzelfde als het juridisch instituut 'vaderschap': een verzameling rechtsregels die uitmaakt welk kind tot welke man behoort, met alle wederzijdse rechten en plichten die daaruit voortvloeien. ${ }^{2}$

2.- Het aftoetsen van die rechtsregels aan de vermelde feitelijke functies van een vader vormt het voorwerp van dit artikel. Meteen wordt benadrukt dat die verschillende functies niet noodzakelijk vereenzelvigd moeten zijn in één persoon. Ik maak daarbij een onderscheid tussen de biologische, de sociale en de juridische vader. ${ }^{3}$ Welk soort vaderschap weegt het meeste door? Of kunnen bepaalde combinaties de balans doen doorslaan naar de ene of de andere kant? Beide vragen worden zowel vanuit Belgisch als Europees standpunt beantwoord.

Kortom, in welke mate houden biologisch, sociaal en juridisch vaderschap gelijke tred in België en wat is de invloed van de rechtspraak van het Europees Hof voor de Rechten van de Mens (hierna: EHRM) de lege late en de lege ferenda?

3.- In een eerste deel wordt het vaderlijke afstammingsrecht besproken. Enkel de oorspronkelijke afstamming zal daarbij aan bod komen. Adoptie, evenals de perikelen omtrent same sex couples, transseksualiteit en de medisch begeleide voortplanting, vallen buiten het bestek van deze bijdrage. ${ }^{4}$ Hetzelfde geldt voor de (pleeg)voogdij. De rechtspositie van de moeder wordt tot slot enkel behandeld in functie van het vaderschap.

\footnotetext{
${ }^{1}$ Geciteerd door Mortelmans, Van Ourti \& Verstreken 2002, p. 47.

${ }^{2}$ Willekens 2006, p. 19.

${ }^{3}$ Voor een goed begrip van de gehanteerde terminologie wordt verwezen naar de inleidende opmerkingen van de Raad van State in haar advies inzake zorgouderschap: Adv. RvS bij het wetsvoorstel van 7 oktober 2005 tot aanvulling van het Burgerlijk Wetboek, met bepalingen inzake het zorgouderschap, Parl. St. 2004-2005, nr. 0393/002.

${ }^{4}$ Veel verder nog gaat de Nederlandse Staatscommissie Herijking Ouderschap. Deze commissie, die is opgericht in april 2014, dient haar eerste rapport uit te brengen voor 1 mei 2016. Verwacht wordt dat zij, behalve de uitgangspunten van het afstammingsrecht, ook de vraagstukken inzake meerouderschap, meeroudergezag en draagmoederschap zal behandelen (Zie: https://www.rijksoverheid.nl/actueel/nieuws/2015/04/13/
} 
Het is niet de bedoeling een exhaustieve beschrijving van het vaderlijke afstammingsrecht te geven. Van de lezer wordt aldus een zekere voorkennis verwacht. Ik beperk mij tot een uiteenzetting van de knelpunten, zoals gebleken uit de recente rechtspraak van het Grondwettelijk Hof. Deze zullen worden gegroepeerd in vier thema's: bezit van staat, vervaltermijnen, belang van het kind en verboden afstamming. Per thema wordt enkel de kwestieuze bepaling toegelicht en de beoordeling van het Grondwettelijk Hof getoetst aan de visie van het EHRM.

4.- In een tweede deel wordt één van de belangrijkste uitvloeisels van de afstammingsband besproken: het ouderlijk gezag. Aan wie komt dit ouderlijk gezag toe en aan wie kan het desgevallend worden ontnomen? En de lege ferenda: moeten afstamming en ouderlijk gezag noodzakelijk hand in hand gaan? Deze vraag vormt overigens de rode draad door het artikel heen. Er wordt hierbij een korte rechtsvergelijkende verkenning gemaakt van problemen en mogelijke oplossingen.

5.- Ten slotte wordt in deel 3 aangehaald waar en hoe het Belgisch recht bepaalde rechten en plichten, gekoppeld aan het juridisch vaderschap, ook al aan andere personen toebedeelt. Ik noem dit: 'de opsplitsing van het vaderschap'. In hoeverre en onder welke voorwaarden kan die lijn worden verder gezet?

6.- Ik rond af met een algemeen besluit. 


\section{- DEEL I. - \\ DE AFSTAMMING LANGS VADERSZIJDE}

\section{ALGEMEEN}

7.- Een bespreking van het concept vaderschap naar Belgisch recht begint bij de regels omtrent de afstamming. Het afstammingsrecht duidt namelijk de persoon aan die zichzelf de juridische vader van een kind mag noemen en zo titularis wordt van de rechten en plichten verbonden aan die titel.

8.- In West-Europese rechtssystemen werd van oudsher de echtgenoot van de geboortemoeder als vader aangeduid, ongeacht of hij het kind verwekt had. Deze regel leverde in het verleden zowel kind als vader voordelen op. ${ }^{5}$ Door de gelijkberechtiging van echtgenoten en de toegenomen rechten van het kind in de Westerse maatschappij onderging deze vanzelfsprekendheid enkele wijzigingen. Vaders hebben steeds meer plichten en minder rechten gekregen, waar voor kinderen en moeders de omgekeerde beweging ingezet is. Onder druk van belangrijke wijzigingen in de samenleving, zoals de DNA-test, nieuwe procreatietechnieken, het toenemend aantal kinderen dat buiten een huwelijk worden geboren (in 2012: 52,3 \%) ${ }^{6}$ en nieuwe samenlevingsvormen, diende de centrale plaats van het huwelijk te worden herzien.

Als grondslagen voor de afstamming gelden vandaag de (vermoedelijke) biologische band, de wil en het bezit van staat. ${ }^{7}$

\section{GRONDWETTELIJK HOF VS. EHRM}

9.- Uit de recente arresten van het Grondwettelijk Hof heb ik vier globale thema's afgeleid die de pijnpunten weergeven in het afstammingsrecht: het bezit van staat, de vervaltermijnen, het belang van het kind en de verboden afstamming. Een artikelsgewijs overzicht wordt voorzien in bijlage. Voor elk thema worden de relevante uitspraken weergegeven en kritisch beoordeeld. Feitenmateriaal wordt slechts aangehaald indien cruciaal voor de bespreking van het arrest. Bij gelijkluidende beoordeling door het Hof worden arresten samen besproken. Per thema wordt tot slot de positie van het EHRM verduidelijkt en vergeleken met de Belgische stand van zaken. Ik rond telkens af met een besluit en een eigen mening.

\footnotetext{
${ }^{5}$ Heyvaert 1979, p. 745 en pp. 762-770.

${ }^{6}$ Kind en Gezin, Het kind in Vlaanderen 2010, www.kindengezin.be/img/kind-in-Vlaanderen-2013.pdf.

${ }^{7}$ Swennen 2007, p. 33, nr. 70. Zie ook G. Verschelden 2005a, pp. 66-164.
} 


\section{BEZIT VAN STAAT}

\subsection{Begrip}

10.- Het bezit van staat kan omschreven worden als "de feitelijke uitoefening van rechten en uitvoering van plichten die verbonden zijn aan een bepaalde juridische staat, onafhankelijk van de vraag of men ook juridische titularis is van die staat",

De wet zelf geeft echter geen definitie van het begrip. Op niet-exhaustieve wijze ("onder meer”) geeft artikel 331nonies Belgische Burgerlijk Wetboek (hierna: BW) zes mogelijke constitutieve bestanddelen die op een afstammingsverhouding ouder-kind kunnen wijzen, doorgaans geplaatst onder de trilogie van nomen, tractatus en fama.

Voor het bezit van staat als kind zijn dit mogelijke beoordelingsfactoren:

- Het kind heeft altijd de naam gedragen van zijn 'vader';'

- De 'vader' heeft het kind altijd als het zijne behandeld;

- De 'vader' heeft in het onderhoud en de opvoeding van het kind voorzien;

- Het kind wordt als het zijne erkend door de familie en in de maatschappij;

- Het kind heeft die man behandeld als zijn 'vader'; en/of

- De overheid beschouwt het als dusdanig.

Dat de opsomming niet limitatief is, betekent dat alle zes elementen niet tegelijk aanwezig hoeven te zijn. Bovendien kan de rechter zich in zijn beoordeling ook baseren op andere feiten dan die in de wet vermeld. ${ }^{10}$

11.- Het bezit van staat moet deugdelijk, ondubbelzinnig en voortdurend zijn. ${ }^{11}$ Allereerst is vereist dat er voldoende betekenisvolle elementen (uit de wet) worden aangevoerd die wijzen op een afstammingsband tussen vader en kind. ${ }^{12} \mathrm{Al}$ die elementen moeten bovendien ondubbelzinnig in dezelfde richting wijzen: er mag geen andere verklaring mogelijk zijn dan het bestaan van een juridische vader-kind-relatie. ${ }^{13}$ Goede trouw, in de zin van onwetendheid over de biologische waarheid, is niet vereist. ${ }^{14}$ Tot slot moet het bezit van staat voortdurend zijn. De wet reikt echter geen termijn aan, waardoor het aan de rechter is om een beoordeling in concreto te maken. ${ }^{15}$ In elk geval is een minimale continuiteit vereist, zonder dat het bezit van staat ononderbroken hoeft te zijn. ${ }^{16}$ Evenmin moet het bezit van staat actueel zijn om definitief verworven te zijn. In het licht van de recente rechtspraak van het Grondwettelijk Hof kan dit evenwel in de beoordeling van de rechter worden betrokken bij een

\footnotetext{
${ }^{8}$ Swennen \& Eggermont 2009, p. 14; Verschelden 2005a, pp. 21-22.

${ }^{9}$ Het dragen van de naam vormt nochtans een louter gevolg van de afstamming en kan m.i. niet ter ondersteuning van die afstamming worden aangevoerd. Zie ook Quirynen 2011a, p. 157.

${ }^{10}$ Quirynen 2011a, pp. 154-156.

${ }^{11}$ Cass. 2 maart 2012, RTDF 2012, 730, m.nt. van J. Sosson.

${ }^{12}$ Wuyts 2011, p. 65.

${ }^{13}$ Verschelden 2005a, p. 25.

${ }^{14}$ Brussel 19 juni 2009, RTDF 2009, 459.

${ }^{15}$ Antwerpen 3 maart 2004, NJW 2004, 1350, m.nt. van G. Verschelden.

${ }^{16}$ Wuyts 2013, p. 135.
} 
betwistingsprocedure (zie infra nr. 23). ${ }^{17}$ De aanwezigheid van bezit van staat is voorts ook niet te verwarren met de geschiktheid als ouder. ${ }^{18}$

12.- In het huidige afstammingsrecht heeft het bezit van staat twee functies: het is een bewijsmiddel bij de gerechtelijke vaststelling van het ouderschap ${ }^{19}$ en een grond van nietontvankelijkheid bij de betwisting van de juridisch gevestigde afstamming. ${ }^{20}$

\subsection{Rol in betwistingsprocedures}

13.- Heeft het kind bezit van staat ten aanzien van de echtgenoot respectievelijk de erkenner, dan wordt de vordering tot betwisting nooit ten gronde behandeld. ${ }^{21}$ Anders gesteld: indien de juridische vader, naast de titel ook een socio-affectieve band als vader heeft opgebouwd met het kind, dan is het bewijs van niet-biologisch vaderschap irrelevant.

14.- Het arrest van 3 februari $2011^{22}$ - Het bezit van staat maakt de vordering tot betwisting onontvankelijk, onafhankelijk van wie ze heeft ingeleid. Is de echtgenoot titularis van de vordering, dan zal het door hem opgebouwde bezit van staat de betwisting van zijn vaderschap in de weg staan. De echtgenoot die het kind te goeder trouw als het zijne opvoedt, beschikt dus niet over een reële betwistingsmogelijkheid. Dit geldt zelfs indien het bezit van staat niet langer actueel is. Het is deze problematiek die aan het arrest van 3 februari 2011 ten grondslag lag.

15.- Het Hof stelt dat er legitieme doelstellingen zijn waarvan de wetgever kan uitgaan om een onbeperkte mogelijkheid tot betwisting van het vaderschap te verhinderen, namelijk enerzijds het belang van het kind en anderzijds de rust der families en de rechtszekerheid van familiale banden. De biologische werkelijkheid mag bijgevolg niet a priori prevaleren boven de socio-affectieve werkelijkheid. ${ }^{23}$ Met artikel 318, §1 BW heeft de wetgever de socioaffectieve werkelijkheid echter steeds laten voorgaan op de biologische. ${ }^{24}$ Het mogelijke belang van het kind om het bezit van staat te genieten, mag het echter niet halen op het legitieme recht van de echtgenoot om ten minste één gelegenheid te krijgen om het vaderschap te betwisten van het kind dat op grond van wetenschappelijke bewijzen niet het zijne is. $^{25}$

De bedrogen echtgenoot te goeder trouw draagt daardoor momenteel bij tot de totstandkoming van de absolute grond van niet-ontvankelijkheid die hem vervolgens kan benadelen. ${ }^{26}$ Een dergelijk automatisme, waar geen enkele belangenafweging door de rechter meer mogelijk is, is volgens het Hof niet bestaanbaar met het recht op eerbiediging van het

\footnotetext{
${ }^{17}$ Swennen 2014, p. 144.

${ }^{18}$ Verschelden 2005a, p. 25.

${ }^{19}$ Zie de artt. 314, lid 4, 324, lid 1 en 331septies, lid 2 BW.

${ }^{20}$ Zie de artt. 312, § 2, 318, § 1 en $330, \S 1$, lid 1 BW.

${ }^{21}$ Verschelden 2013a, p. 37.

${ }^{22}$ GwH 3 februari 2011, nr. 20/2011, Act.dr.fam. 2011, 75, m.nt. van N. Gallus; T. Fam. 2011, 61, m.nt. van T. Wuyts.

${ }^{23} \mathrm{GwH} 3$ februari 2011, nr. 20/2011, r.o. B.9.

${ }^{24}$ GwH 3 februari 2011, nr. 20/2011, r.o. B.10.

${ }^{25} \mathrm{GwH} 3$ februari 2011, nr. 20/2011, r.o. B.8.

${ }^{26}$ GwH 3 februari 2011, nr. 20/2011, r.o. B.10.
} 
privéleven. ${ }^{27}$ Het dictum van het arrest beperkt zich echter - onterecht - niet tot de situatie waarin de echtgenoot de vordering instelt.

16.- T. WUYTS meent dat sinds het arrest van 3 februari 2011 elke vordering tot betwisting van het vaderschap van de echtgenoot ontvankelijk dient te worden verklaard, zelfs al bestaat er tussen hem en het kind een deugdelijk bezit van staat. ${ }^{28,29}$ Het bezit van staat verliest zo zijn rol als gatekeeper, maar blijft belangrijk op het niveau van de procedure ten gronde.

Met F. SWENNEN ${ }^{30}$ en G. VERSCHELDEN ${ }^{31}$ meen ik dat een genuanceerdere interpretatie aan het arrest moet worden gegeven. Het bezit van staat vormt geen absolute grond van nietontvankelijkheid meer. Dit betekent niet dat de sluizen nu openstaan voor elke vordering. Er moet wel ruimte worden gecreëerd voor bepaalde uitzonderingen. Zijn er bijzondere omstandigheden voorhanden dan moet de rechter in concreto kunnen afwijken van het principe van niet-ontvankelijkheid.

17.- Dit arrest is in de rechtsleer op zeer verschillende manieren onthaald. ${ }^{32} \mathrm{Zij}$ die het bekritiseren leggen de nadruk op de verregaande beoordelingsbevoegdheid van de rechter inzake afstammingskwesties die met het arrest is gecreëerd en op de foutieve toepassing van de arresten van het EHRM. ${ }^{33}$

Aan het eerste punt kan mijns inziens al tegemoet gekomen worden met de interpretatie van het arrest door F. SWENNEN en G. VERSCHELDEN: de rechter kan vanaf nu slechts in bijzondere gevallen een uitzondering toestaan op het principe van niet-ontvankelijkheid (zie supra, nr. 16).

Wat betreft de interpretatie van de Europese rechtspraak, is dit arrest het eerste waarin het Grondwettelijk Hof toetst aan artikel 22 Gw. sinds de toetsingsbevoegdheid werd verruimd naar alle artikelen van titel II van de Grondwet. Het Hof haalt daarom uitdrukkelijk aan dat uit de parlementaire voorbereidingen van artikel $22 \mathrm{Gw}$. blijkt dat er een zo groot mogelijke concordantie diende te worden nagestreefd met artikel 8 EVRM ${ }^{34}$ Het is dan ook logisch dat het Hof inspiratie zocht in de tot dan toe beschikbare rechtspraak van het EHRM. ${ }^{35}$ Sommige auteurs menen dat er sprake is van een "blinde volgzaamheid van de Straatsburgse rechtspraak" $"$. De arresten die het Grondwettelijk Hof aanhaalt, werden immers geenszins in dezelfde feitelijke of juridische context gewezen. Het Hof heeft een aantal stelregels uit die arresten afgeleid en naar analogie toegepast op het bezit van staat. Het EHRM vaardigt nochtans geen regelgeving uit, maar controleert of in een specifieke zaak bepaalde rechten

\footnotetext{
${ }^{27}$ GwH 3 februari 2011, nr. 20/2011, r.o. B.10 en 11.

${ }^{28}$ Wuyts 2011, p. 73, nr. 25.

${ }^{29}$ Bergen 14 mei 2012, RTDF 2012, 796; Act.dr.fam. 2012, 140, waar dit arrest naar analogie werd toegepast bij een vordering door de biologische vader.

${ }^{30}$ Swennen $2011 \mathrm{a} / 12$, pp. $44-45$.

${ }^{31}$ Verschelden 2013a, p. 39.

32 Massager 2011, pp. 134-135; Leleu 2013, pp. 10-12, nr. 2 en pp. 15-17, nr. 6. Kritisch: Sosson 2013a, pp. 113-118; Swennen 2011b/12, pp. 102-107; Senaeve 2011, pp. 170-171.

${ }^{33}$ Zie bijv. Gallus 2013a, pp. 1352-1368, waar beide punten uitvoerig worden aangehaald.

${ }^{34}$ GwH 3 februari 2011, nr. 20/2011, r.o. B.4.

${ }^{35}$ Rasson-Roland \& Sosson 2011, p. 597.

${ }^{36}$ Senaeve 2011, p. 171
} 
geschonden zijn. Uitspraken in een bepaalde zaak kunnen dus niet zomaar worden getransponeerd naar een andere situatie, ook al bestaat er een zekere mate van vergelijkbaarheid. ${ }^{37}$

18.- De rechtspraak van het EHRM - Het recht om een afstammingsband, gevestigd door een wettelijk vermoeden, ${ }^{38}$ een erkenning, ${ }^{39}$ of een gerechtelijke vaststelling ${ }^{40}$ weerlegd te zien in het licht van biologische bewijzen, valt volgens het EHRM minstens onder het recht op eerbiediging van het privéleven, zelfs indien de vordering gericht is op de verbreking van een bestaande familiale band. ${ }^{41}$ Hetzelfde geldt voor het recht van een (vermeende) biologische vader om een vordering tot betwisting en vaststelling van een afstammingsband in te stellen. ${ }^{42}$

19.- Dat een zaak onder het toepassingsgebied van artikel 8 EVRM valt, betekent evenwel nog niet dat er een schending moet worden vastgesteld. In het arrest-Kroon oordeelde het EHRM dat een eerbiediging van het familie- en gezinsleven vereist dat de biologische en sociale werkelijkheid primeert op een wettelijk vermoeden wanneer dat lijnrecht ingaat tegen de vastgestelde feiten en de wensen van de betrokkenen, zonder dat iemand er een voordeel uit haalt. ${ }^{43}$ In het Belgische arrest van 3 februari 2011 was er echter tot voor kort wel een sociale werkelijkheid en was het geenszins de wens van alle betrokken om dit vaderschap op te breken. De Kroon-rechtspraak kan daarom niet naar analogie worden toegepast. ${ }^{44}$

20.- Wel relevant is het standpunt van het EHRM in de arresten-Ahrens en Kautzor van 22 maart 2012. ${ }^{45}$ In beide zaken werd een kind erkend door de nieuwe partner van de moeder en werd het juridische vaderschap betwist door de (beweerde) biologische vader. Het Duitse recht voorzag echter dat die vordering, uitgaande van de biologische vader, enkel kon worden behandeld indien er tussen juridische vader en kind geen sozial-familiäre Beziehung - een begrip vergelijkbaar met bezit van staat - bestaat. ${ }^{46}$ In de zaak-Ahrens besloot het Hof dat er tussen kind en biologische vader geen sprake was van een familie- en gezinsleven. De relatie tussen de natuurlijke ouders was er één van louter seksuele aard, zonder de bedoeling om een gezin te stichten. De verwekker had voor de geboorte ook geen blijk gegeven van interesse of engagement naar het kind toe (\$59). De zaak kon hoogstens een inmenging vormen in het recht op eerbied voor het privéleven van de verwekker (\$60). Het Hof kwam tot een vergelijkbare conclusie in de zaak-Kautzor. Hier werd bovendien ook het bestaan van een biologische band betwist ( $\$ 62)$.

\footnotetext{
${ }^{37}$ Gallus \& Van Gysel 2013, p. 399.

${ }^{38}$ EHRM 24 november 2005, 74826/01 (Shofman/Rusland), §§ 30-31; EHRM 12 januari 2006, 26111/02 (Mizzi/Malta), §§ 102-103; EHRM 9 november 2006, 11449/02 (Tavli/Turkije), §§ 25-26.

${ }^{39}$ EHRM 9 maart 2010, 35016/07 (Wulff/Denemarken).

${ }^{40}$ EHRM 10 oktober 2006, 10699/05 (Paulik/Slowakije), §§ 41-42.

${ }^{41}$ EHRM 21 november 1984, 8777/79 (Rasmussen/Denemarken), § 33.

${ }^{42}$ EHRM 22 maart 2012, 45071/09 (Ahrens/Duitsland), § 60 en EHRM 22 maart 2012, 23338/09 (Kautzor/Duitsland), § 63.

${ }^{43}$ EHRM 27 oktober 1994, 18535/91 (Kroon e.a./Nederland), § 40.

${ }^{44}$ Rasson-Roland \& Sosson 2011, p. 602.

${ }^{45}$ EHRM 22 maart 2012, 45071/09 (Ahrens/Duitsland) en EHRM 22 maart 2012, 233338/09 (Kautzor/Duitsland).

${ }^{46}$ Art. 1600, § 4 BGB.
} 
Het Hof stelt dat er uit artikel 8 EVRM geen verplichting voor de staten kan worden afgeleid om de biologische vader toe te laten het juridisch vaderschap te betwisten. Er bestaat bovendien geen consensus tussen de lidstaten ter zake. De staat beschikt derhalve over een ruime beoordelingsmarge om te bepalen of onder deze omstandigheden de biologische vader over een vordering tot betwisting moet beschikken (Kautzor, $\$ 78$ en Ahrens, §75). De nationale rechter mag de vordering tot betwisting onontvankelijk verklaren indien het juridische vaderschap bevestigd wordt door een sociaal-familiale relatie.

21.- Met deze arresten lijkt de discussie ook voor België beslecht. De beslissing van de wetgever om van bezit van staat een absolute grond van niet-ontvankelijkheid te maken, valt binnen zijn beoordelingsmarge.

We mogen evenwel niet uit het oog verliezen dat de casuspositie in de zaken voor het EHRM niet dezelfde was als die in het arrest van het Grondwettelijk Hof van 3 februari 2011. Hier was het niet de verwekker, maar wel de echtgenoot die door het bezit van staat dat hij had opgebouwd, verhinderd werd zijn vaderschap te betwisten. Bovendien bestond er in de zaakAhrens tussen juridische vader en kind een actuele band van gezins- en familieleven, terwijl er naar Belgisch recht vooralsnog geen actualiteitsvereiste geldt voor het bezit van staat. De arresten-Kautzor en Ahrens dateren overigens van 22 maart 2012, meer dan een jaar na de eerste uitspraak van het Grondwettelijk Hof over het bezit van staat als grond van nietontvankelijkheid. Het Hof heeft zich gebaseerd op de toen heersende rechtspraak van het EHRM. ${ }^{47}$ Hetzelfde kan echter niet worden gezegd van de arresten die het na 2012 heeft geveld.

22. In de nasleep van Ahrens en Kautzor - Ondanks de zeer heldere rechtspraak van het EHRM heeft het Grondwettelijk Hof de 'afbraak' van het bezit van staat als grond van nietontvankelijkheid voortgezet. Ook indien de beweerde biologische $\operatorname{vader}^{48}$ of het kind ${ }^{49}$ titularis is van de vordering mag het bezit van staat geen beoordeling in concreto verhinderen. Hetzelfde geldt voor de betwisting van de erkenning door de verwekker, ${ }^{50}$ het kind $^{51}$ of de man die het kind heeft erkend ${ }^{52}$. Deze laatste mag enkel de erkenning betwisten indien hij bewijst dat aan zijn toestemming een gebrek kleefde ${ }^{53}$-een voorwaarde die recentelijk nog door het Grondwettelijk Hof grondwetsconform werd geacht. ${ }^{54}$

\footnotetext{
${ }^{47}$ Gallus \& Van Gysel 2013, p. 376.

${ }^{48}$ GwH 9 juli 2013, nr. 105/2013, JLMB 2013, 1349, m.nt. van N. Gallus; T. Fam. 2013, 220, m.nt. van T. Wuyts.

${ }^{49}$ GwH 7 november 2013, nr. 147/2013, Act.dr.fam. 2014, afl. 3, 66; RTDF 2014, afl. 2, 385; RW 2013-14, afl. $17,679$.

${ }^{50}$ GwH 7 maart 2013, nr. 29/2013, Act.dr.fam. 2013, 73, m.nt. van N. Gallus; RTDF 2013, 557, m.nt. van J. Sosson; T. Fam. 2013, 216, m.nt. van T. Wuyts; en GwH 9 juli 2013, nr. 96/2013, JLMB 2013, 1344, m.nt. van N. Gallus; T. Fam. 2013, 218 , m.nt. van T. Wuyts.

${ }^{51}$ GwH 26 november 2015, nr. 168/2015.

${ }^{52}$ GwH 19 september 2014, nr. 127/2014, RW 2014/15 (samenvatting), afl. 7, 279 en www.rw.be/ en GwH 25 september 2014, nr. 139/2014, RW 2014/15 (samenvatting), afl. 7, 279 en www.rw.be/. In dezelfde zin: GwH 12 maart 2015, nr. $32 / 2015$.

${ }_{53}^{5}$ Art. 330, § 1, lid 2 BW. Zulks geldt eveneens voor de andere toestemmingsgerechtigden bij de erkenning.

${ }^{54}$ Voor de 'erkenner': GwH 19 september 2014, nr. 127/2014, impliciet in r.o. B.2.2. en het dictum en GwH 25 september 2014, nr. 139/2014, r.o. B. 26 - B.31. In dezelfde zin: GwH 19 maart 2015, nr. 38/2015. Voor de moeder: GwH 24 september 2015, nr. 126/2015.
} 
Het Grondwettelijk Hof heeft er bewust voor gekozen de Europese rechtspraak niet te volgen. Tegen het advies van de Ministerraad in stelde het Hof immers dat aan zijn zienswijze geen afbreuk werd gedaan door de arresten-Ahrens en Kautzor. ${ }^{55}$ Gelet op zijn 'blinde volgzaamheid' ten aanzien van eerdere rechtspraak van het EHRM is dit een vreemde wending. ${ }^{56}$ Om alsnog tot een schending te kunnen besluiten, wijst het op de appreciatiemarge die het EHRM aan de wetgever toekent. ${ }^{57}$ Een argument dat mijns inziens eerder de tegenovergestelde visie onderbouwt.

23. Quid bezit van staat? - Ik sluit mij aan bij de stelling van N. GALLUS, die zegt dat de discussie verplaatst dient te worden naar de invulling van het begrip bezit van staat. ${ }^{58}$ Bezit van staat veronderstelt immers 'slechts' dat men zich gedraagt - en dat dit ook zo wordt waargenomen - alsof er een juridische afstammingsband bestaat. Dit is een engere definitie dan die van sociale werkelijkheid. Bezit van staat hoeft immers niet actueel te zijn. ${ }^{59}$

Om die reden pleit A. QUIRYNEN ervoor om in de wet de vereisten voor het bezit van staat aan te passen aan de functie die het vervult. In een procedure tot betwisting van staat zou bijvoorbeeld een actualiteitsvereiste kunnen worden toegevoegd. ${ }^{60}$ Gevolg is dat biologische vaders niet langer geblokkeerd kunnen worden indien de juridische vader geen relatie (meer) onderhoudt met het kind. Gevaar bestaat erin dat vaders die zich van hun eigen vaderschap willen ontdoen, eenvoudigweg contact verbreken in de aanloop naar een procedure, en dit terwijl er niet noodzakelijk een andere kandidaat de rol kan of wil overnemen. ${ }^{61}$ Dit zou eventueel kunnen worden verholpen door toe te voegen dat de niet-actualiteit niet het gevolg mag zijn van een eigen beslissing. Desalniettemin is vooralsnog het uitgangspunt dat eens verworven, het bezit van staat ook definitief vaststaat. $^{62}$

24.- De algemene idee dat het bezit van staat in zijn huidige vorm niet meer voldoet als grond van niet-ontvankelijkheid kan wel worden bijgetreden. ${ }^{63}$ Mogelijke wijzigingen zijn dan: (1) de criteria voor bezit van staat verfijnen; (2) het bezit van staat schrappen en vervangen door andere criteria die een verdere beoordeling in concreto inhouden; of (3) naast het huidige bezit van staat ook andere criteria van een meer socio-affectieve aard aan de wet toevoegen. In elk van de voorgedragen wijzigingen zal meer aansluiting worden gevonden bij het begrip gezinsleven uit artikel 8 EVRM.

\footnotetext{
${ }^{55}$ Zie GwH 7 maart 2013, nr. 29/2013, r.o. B.11 en GwH 9 juli 2013, nr. 96/2013, r.o. B.11.

${ }^{56}$ Gallus 2013a, p. 1365.

${ }^{57}$ GwH 3 februari 2011, nr. 20/2011, r.o. B.11.

${ }^{58}$ Gallus 2011, pp. 78-79.

${ }^{59}$ Wuyts 2013, p. 137, nr. 151.

${ }^{60}$ Quirynen 2011, pp. 154-160, nr. 22.

${ }^{61}$ Gallus 2013a, p. 1362.

${ }^{62}$ Swennen 2014, p. 143.

${ }^{63}$ In diezelfde zin: Gallus 2011, pp. 78-79.
} 


\section{VERVALTERMIJNEN}

\subsection{Betwisting vaderschap van de echtgenoot}

25. De vordering van het kind (GwH 31 mei 2011, nr. 96/2011) ${ }^{64}$ - Krachtens artikel 318, $\S 2$, eerste lid BW kan de vordering tot betwisting van vaderschap door het kind worden ingesteld ten vroegste vanaf de leeftijd van 12 jaar en uiterlijk op de dag waarop het de leeftijd van 22 jaar heeft bereikt. Ontdekt het kind pas later dat de echtgenoot van zijn moeder niet zijn vader is, dan moet de vordering binnen het jaar na de ontdekking worden ingesteld.

26.- In deze zaak ging het om een man van 40 jaar oud wiens wettelijke vader overleden was. Tussen hen beiden was geen bezit van staat tot stand gekomen, daar de vader zich niet meer om zijn kind had bekommerd sinds hij vlak na de geboorte van de moeder was gescheiden. In 2000 bleek bovendien uit DNA-onderzoek dat een andere man hem verwekt had. In 2010 stelde het kind daarop een vordering tot betwisting van het vermoeden van vaderschap in, ruimschoots acht jaar te laat.

Aan het Hof werden twee vragen voorgelegd. Eerst werd gepeild naar de verenigbaarheid van een vervaltermijn die het kind verhindert om een afstammingsband aan te vechten, zonder dat die inmenging wordt verantwoord door een concreet en daadwerkelijk belang. ${ }^{65}$ De tweede vraag had betrekking op de discrepantie tussen huwelijkse kinderen, die vanaf de meerderjarigheid slechts over één jaar tijd beschikken om het vaderschap te betwisten, en buitenhuwelijkse kinderen, die tot 48 jaar lang een vordering tot vaststelling van het vaderschap kunnen inleiden. ${ }^{66,67}$

27.- In het arrest van 31 mei 2011 overweegt het Hof allereerst dat het vaststellen van een 'verjaringstermijn' kan worden verantwoord om zo de rechtszekerheid en een definitief karakter van de familiale relaties te waarborgen. ${ }^{68}$ Een onbeperkte mogelijkheid tot betwisting kan aldus worden verhinderd ter bescherming van de rust der families en de stabiliteit van familiale banden enerzijds, en het belang van het kind anderzijds. Nochtans, in de gevallen waarin het juridisch vaderschap niet overeenstemt met de biologische of socio-affectieve werkelijkheid, is een dergelijke korte 'verjaringstermijn' strijdig met de artikelen 10, 11 en 22 van de Gw., in samenhang met de artikelen 8 en 14 EVRM. De rust der families kan immers niet verantwoorden dat een kind op absolute wijze de toegang tot de rechter wordt ontzegd, terwijl de familiale banden in casu onbestaande waren. ${ }^{69}$

28.- N. MASSAGER meent dat de rechter de termijn naast zich neer moet kunnen leggen indien na een belangenafweging in concreto zou blijken dat de juridische afstammingsband een lege

\footnotetext{
${ }^{64}$ GwH 31 mei 2011, nr. 96/2011, Act.dr.fam. 2011, 142, m.nt. van N. Massager; RW 2010-11, 1791, m.nt. van F. Swennen; T. Fam. 2011, 214, m.nt. van A. Quirynen.

${ }^{65}$ GwH 31 mei 2011, nr. 96/2011, r.o. B.1.1

${ }^{66}$ Art. 331ter BW.

${ }^{67}$ GwH 31 mei 2011, nr. 96/2011, r.o. B.1.2

${ }^{68}$ GwH 31 mei 2011, nr. 96/2011, r.o. B.12.

${ }^{69}$ GwH 31 mei 2011, nr. 96/2011, r.o. B.14.
} 
huls is. Een louter abstract juridisch concept mag in geen geval de wil van het individu dwarsbomen. ${ }^{70}$

F. SWENNEN ${ }^{71}$ en G. VERSCHELDEN ${ }^{72}$ nemen opnieuw een genuanceerdere stelling in: niet de vervaltermijn op zich, maar enkel het absolute karakter ervan zou door het Hof ongrondwettig zijn geacht. Afwijken moet mogelijk zijn indien de rechter vaststelt dat het recht in casu voor de verzoeker geen echte vorderingsmogelijkheid heeft gecreëerd.

29.- F. SWENNEN legt enkele zwakke plekken in het arrest bloot. ${ }^{73}$ Ten eerste spreekt het Hof telkens van een verjaringstermijn terwijl de termijn waarvan sprake in artikel $318, \S 3 \mathrm{BW}$ duidelijk een vervaltermijn is. ${ }^{74}$ Dit betekent dat een beroep op de figuur van overmacht mogelijk is. ${ }^{75}$ Door de aard van de wettelijke termijn juist te kwalificeren wordt het absolute karakter van de grond van niet-ontvankelijkheid al meteen genuanceerd, zonder evenwel de onverantwoorde passieve houding van de verzoeker te belonen.

Ten tweede neemt het Hof onterecht aan dat een vordering tot betwisting van staat dezelfde behandeling vereist als een vordering tot inroeping van staat. De stelling dat voortaan de dertigjarige termijn van artikel 331ter BW zou gelden, bij wijze van 'egalisering', ${ }^{76}$ kan daarom niet worden gevolgd.

Tot slot mogen overwegingen van algemeen belang, zoals de rust der families en de rechtszekerheid der familiale banden, niet zomaar hun waarde verliezen naargelang hun aanof afwezigheid in een concrete situatie. Het vrijelijk interpreteren van het algemeen belang in functie van een individuele positie leidt tot de uitholling van het begrip.

De stelling van het Hof is nochtans duidelijk: een absolute vervaltermijn, als abstracte norm gericht op de bescherming van theoretische maatschappelijke belangen, mag niet prevaleren boven het persoonlijk belang van een kind om zich te ontdoen van een betekenisloze afstammingsband. ${ }^{77}$

30.- Met F. SWENNEN en G. VERSCHELDEN meen ik dat een afwijking van het principe van niet-ontvankelijkheid bij het verstrijken van een vervaltermijn slechts bij uitzondering mag worden toegestaan. Het bewijzen van overmacht en het aantonen van een de facto onbestaande vorderingsmogelijkheid zijn in die zienswijze de enige mogelijke correcties. Werd de vordering laattijdig ingediend om een andere reden, dan komt de betrokkene niet in

\footnotetext{
${ }^{70}$ Massager 2011, p. 136.

${ }^{71}$ Swennen 2011/12, pp. 1108-1109.

${ }^{72}$ Verschelden 2013a, p. 39.

${ }^{73}$ Swennen 2011b/12, pp. 1107-1109.

${ }_{75}^{74}$ In dezelfde zin: Quirynen 2011b, p. 221, nr. 20.

${ }^{75}$ Broeckx, Laenens, Scheers e.a. 2008, pp. 129-130, nrs. 218-219.

${ }^{76}$ Verhoeven 2011, pp. 4-5, nr. 231.

77 Zie ook Massager 2011, p. 136, waar de auteur spreekt van een "coquille vide" in de mate dat de juridische afstammingsband niet ondersteund wordt door een socio-affectieve of biologische band.
} 
aanmerking voor het uitzonderingsregime, i.e. de mogelijkheid tot een beoordeling ten gronde. ${ }^{78}$ Deze stelling is helaas moeilijk te rijmen met de bewoordingen in het dictum. ${ }^{79}$

31.- In het licht van het arrest zullen de hoven en rechtbanken voortaan de vordering van het kind tot betwisting van het vaderschap van de echtgenoot steeds ontvankelijk kunnen verklaren bij afwezigheid van biologische en socio-affectieve werkelijkheid, ook indien de vervaltermijn van één jaar reeds verstreken is.

32. De vordering van de echtgenoot (GwH 28 maart 2013, nr. 46/2013) ${ }^{80}$ - Opdat de vordering van de echtgenoot tot betwisting van zijn vaderschap ontvankelijk zou kunnen worden verklaard, moet ze krachtens artikel 318, §2 BW worden ingesteld binnen het jaar na de ontdekking van het feit dat hij niet de vader van het kind is. Het absolute karakter van deze termijn was eveneens voorwerp van een prejudiciële vraag.

33.- Het wettelijke vaderschap werd ook hier niet ondersteund door een biologische of socioaffectieve band. De kinderen werden al jarenlang door de nieuwe partner van de moeder opgevoed, die bovendien de biologische ouder bleek te zijn. Deze laatste was meer dan bereid de kinderen te erkennen nadat de juridische banden met de ex-echtgenoot waren doorgeknipt. Gelet op het dictum van het arrest van 31 mei 2011 meende de wettelijke vader dat een uitzondering moest worden toegelaten op de onontvankelijkheid van de vordering.

34.- Aanvankelijk is de motivering van het Hof zeer gelijklopend met die van het arrest van 31 mei 2011. In rechtsoverwegingen B.8.2 en B.8.3 helt het Hof echter volledig over naar de andere kant. Met een beroep op de Europese rechtspraak inzake de principiële toelaatbaarheid van termijnen en de appreciatiemarge van de wetgever ter zake, stelt het Hof dat "de wetgever vermocht te oordelen dat hij die huwt in beginsel aanvaardt om beschouwd te worden als vader van ieder kind dat zijn vrouw zal baren.",81

Een korte vervaltermijn voor de echtgenoot is niet onredelijk gezien de legitieme doelstellingen van de wetgever zoals de rust der families en de rechtszekerheid van de familiale banden enerzijds en het belang van het kind anderzijds. ${ }^{82}$ De rechter beslist bovendien soeverein over wat moet worden verstaan onder "kennisname van het feit dat de echtgenoot niet de vader is." 83

\footnotetext{
${ }^{78}$ Swennen 2011a/12, p. 44, nr. 8.

${ }^{79}$ In die zin Quirynen 2011b, pp. 221-222, nr. 21. Desondanks pleit ook zij voor het behoud van de éénjarige vervaltermijn als uitgangspunt.

${ }^{80}$ GwH 28 maart 2013, nr. 46/2013, RABG 2013, 903, m.nt. van B. Lambersy en C. Vergauwen; RTDF 2013, 535, m.nt. van J. Sosson.

${ }^{81}$ Zie ook Arbitragehof 21 december 2000, nr. 138/2000, BS 8 maart 2001, r.o. B.7; Arbitragehof 12 juli 2001, nr. 95/2001, BS 13 november 2001, r.o. B.9, waar op dezelfde manier de ratio legis achter de vervaltermijn tot betwisting van het vaderschap werd verwoord.

${ }^{82}$ GwH 28 maart 2013, nr. 46/2013, r.o. B.9 - B.10.2.

${ }^{83}$ GwH 28 maart 2013, nr. 46/2013, r.o. B.10.3.
} 
Het Hof eindigt met de open stelling dat er behalve de echtgenoot nog andere vorderingsgerechtigden zijn voor de betwisting van het vaderschap van de echtgenoot, m.n. het kind en de beweerde biologische vader. ${ }^{84}$

35.- De omwenteling in de rechtspraak van het Hof is opvallend. Punt van discussie is opnieuw het absolute karakter van de vervaltermijn, maar op grond van een vergelijkbare motivering besluit het Hof ditmaal niet tot een schending. Nochtans, in beide gevallen hadden de eisers in het geding hun daadwerkelijke betwistingsmogelijkheid laten voorbijgaan zonder daartoe een dwingende reden te kunnen voorleggen en was er geen biologische band, noch bezit van staat tussen wettelijke vader en kind. Verzoekers hadden telkens te maken met een vervaltermijn uit artikel 318, §2 BW met als vertrekpunt "de ontdekking van het feit dat de echtgenoot het kind niet heeft verwekt" en als duurtijd één jaar. Het onderscheid bestond erin dat er sprake was van een verschillende titularis en toetsingsmaatstaf. Voor het kind ging het om het recht op eerbiediging privéleven van het kind (art $22 \mathrm{Gw}$.), in combinatie met de artikelen 10 en $11 \mathrm{Gw}$ ( $\mathrm{j}^{\circ}$ art. 8 en 14 EVRM). Wat de echtgenoot betreft kan enkel het recht op eerbiediging van privéleven van de echtgenoot (art. $22 \mathrm{Gw}$, $\mathrm{j}^{\circ}$ art. 8 EVRM) worden aangehaald. ${ }^{85}$ Er kan bijgevolg helaas niet worden voorondersteld dat het Grondwettelijk Hof op zijn eerdere rechtspraak is teruggekomen.

36.- Het Hof eindigt evenwel met twee interessante opmerkingen: allereerst, de feitenrechter beslist soeverein over de manier waarop hij het begrip "kennisnemen van het feit dat de juridische afstammingsband niet overeenstemt met de biologische realiteit" beoordeelt. Een absolute zekerheid - in feite enkel te verkrijgen via de resultaten van een DNA-onderzoek is m.i. niet vereist, maar de rechter kan dus anders oordelen. ${ }^{86}$ Krachtens artikel 331octies BW kan ook ambtshalve een genetisch onderzoek worden gelast, in welk geval de rechter kan bepalen dat het tijdstip van de uitkomst van dat onderzoek als startpunt van de termijn moet worden beschouwd. ${ }^{87} \mathrm{Ik}$ meen hierin een derde nuancering (zie supra nr. 30) te vinden van het absolute karakter van de vervaltermijn. Werd geen voorafgaand (door de rechter gelast) DNA-onderzoek gedaan dan behoudt de rechter de mogelijkheid om de vordering ontvankelijk te verklaren.

Ten tweede verantwoordt het Hof het verschil in behandeling tussen echtgenoot en kind door te wijzen op de alternatieve betwistingsmogelijkheden. ${ }^{88}$ Echter in casu zal ook de vordering van de biologische vader wellicht verjaard zijn. Vanaf de leeftijd van 12 jaar hebben de kinderen nog ruimschoots de tijd om het vaderschap aan te vechten, des te meer in het licht van arrest van 31 mei $2011 .^{89}$ Zulks zal evenwel niet altijd het geval zijn.

\footnotetext{
${ }^{84}$ GwH 28 maart 2013, nr. 46/2013, r.o. B.11.

${ }^{85}$ Quirynen 2014, pp. 43-44.

${ }^{86}$ Swennen 2014, p. 357.

${ }^{87}$ GwH 28 maart 2013, nr. 46/2013, RABG 2013, 903, m.nt. van B. LAMBERSY en C. VergaUwen; RTDF 2013, 535, m.nt. van J. SosSON, r.o. B.10.3.

${ }^{88}$ Sosson 2013b, pp. 554-555, nrs. 11-12.

${ }^{89}$ Sosson 2013b, pp. 554-555, nr. 12.
} 
37. En de overige vorderingsgerechtigden? - In 2014 hebben ook de vervaltermijnen voor de vordering van de beweerde biologische vader $^{90}$ en die van de moeder ${ }^{91}$, beide vervat in artikel 318, §2 BW de toets van het Hof doorstaan.

In beide zaken was er wederom geen bezit van staat, noch een biologische band tussen de wettelijke vader en de kinderen en hadden de titularissen de termijn om een vordering tot betwisting te kunnen instellen laten verstrijken. Voor de biologische vader komt het Hof tot hetzelfde besluit als in het arrest van 28 maart 2013 op grond van een vergelijkbare motivering. ${ }^{92}$ Ook voor de man die het vaderschap opeist is een korte termijn om het vaderschap van de echtgenoot te betwisten redelijk verantwoord. ${ }^{93}$

38.- Als laatste in de rij is ook de vervaltermijn van de moeder aan bod gekomen. In tegenstelling tot de biologische vader, de echtgenoot en het kind ouder dan 22, ligt het aanvangspunt van de termijn voor de moeder niet bij de kennis over de biologische waarheid maar bij de geboorte. Behalve het in vraag stellen van het absolute karakter van de termijn wordt dit keer ook gepeild naar de grondwettigheid. Het verschil in behandeling wordt volgens het Hof redelijkerwijze verantwoord door het feit dat de moeder op het ogenblik van de geboorte in principe op de hoogte is van de mogelijkheid dan wel van het gegeven dat haar echtgenoot niet de biologische vader van haar kind is. ${ }^{94}$ Voor het overige is het arrest weer zeer gelijklopend.

39.- Mutatis mutandis gelden hier dezelfde bedenkingen als in randnummers 35 en 36 .

\subsection{Betwisting vaderschap van de erkenner}

40. Duur (GwH 17 oktober 2013, nr. 139/2013) ${ }^{95}$ - De man die het vaderschap opeist, moet krachtens artikel 330, $\$ 1$, lid 4 BW zijn vordering tot betwisting van een vaderlijke erkenning inleiden binnen het jaar na de ontdekking dat hij het kind heeft verwekt. De persoon die het kind heeft erkend, beschikt eveneens slechts over één jaar om zijn erkenning te betwisten, vertrekkende van de ontdekking van het feit dat hij niet de vader is. ${ }^{96}$ Zoals gezegd, geldt daarbij de bijkomende voorwaarde van een gebrekkige toestemming tot de erkenning (zie supra nr. 22). ${ }^{97}$ Wordt de vordering laattijdig ingediend, dan is ze net als bij de betwisting van het vaderschap van de echtgenoot steeds onontvankelijk.

\footnotetext{
${ }^{90}$ GwH 29 januari 2014, nr. 16/2014, Act.dr.fam. 2014, afl. 3, 59 en GwH 9 oktober 2014, nr. 145/2014, www.const-court.be.

${ }^{91}$ GwH 20 maart 2014, nr. 46/2014, RTDF 2014, afl. 2, 388; RW 2013-14, afl. 33, 1320.

${ }^{92}$ De verwijzing naar de alternatieve betwistingsmogelijkheden werd echter niet hernomen.

${ }^{93}$ GwH 29 januari 2014, nr. 16/2014, r.o. B.10.

${ }^{94}$ GwH 29 januari 2014, nr. 16/2014, r.o. B.13.

${ }^{95}$ GwH 17 oktober 2013, nr. 139/2013, Act.dr.fam. 2014, afl. 3, 71; RTDF 2013, afl. 4, 1045, m.nt. van G. Mathieu en GwH 5 december 2013, nr. 165/2013, Act.dr fam. 2014, afl. 3, 62; T. Fam. 2014, afl.2, 39, m.nt. van A. Quirynen. Zie ook GwH 25 september 2014, nr. 139/2014, www.const-court.be.

${ }^{96}$ Art. 330, §1, lid 4 BW.

${ }^{97}$ Art. 330, §1, lid 2 BW.
} 
Voor deze beide titularissen werd de vraag aan het Hof gesteld of deze absolute grond van niet-ontvankelijkheid grondwetsconform is. Het antwoord blijft hetzelfde: een korte termijn om het vaderschap te betwisten, is verantwoord. ${ }^{98}$

41. Vertrekpunt: Termijn vangt aan voor erkenning plaatsvindt (GwH 6 april 2011, nr. 54/2011 $)^{99}$ - Net als voor de betwisting van het vaderschap van de echtgenoot maakt de ontdekking van de biologische werkelijkheid het aanvangspunt uit voor de eenjarige vervaltermijn. ${ }^{100}$ Nochtans is er een opmerkelijk verschil tussen beide vormen van juridisch vaderschap: daar waar het vaderschap van de echtgenoot vaststaat vanaf de geboorte van het kind, is dit niet het geval voor het vaderschap door erkenning. Het tijdstip is afhankelijk van het initiatief van de erkenner en bijgevolg niet vast bepaald. ${ }^{101}$

42.- Nadat de moeder haar toestemming voor de erkenning had geweigerd, leidde de eiser in het geding de procedure van artikel 329bis BW in. Tijdens die procedure liet de moeder het kind erkennen door een andere man, die niet de biologische vader was. Op het moment van die erkenning was de eiser al meer dan een jaar op de hoogte van het feit dat hij het kind verwekt had. Volgens de letter van de wet moest de vordering bijgevolg onontvankelijk worden verklaard, ondanks het feit dat er tijdens de vervaltermijn geen erkenning was geweest om te betwisten.

43.- Het Hof stelt vast dat er een wezenlijk verschil bestaat tussen het vaderschapsvermoeden en de erkenning met betrekking tot het tijdstip van de vestiging van het vaderschap. ${ }^{102}$ De doelstelling om in geharmoniseerde procedureregels te voorzien voor alle types van betwistingen, mag niet tot gevolg hebben dat voor een bepaald type vaderschapsbetwisting de vordering van de biologische vader onmogelijk kan worden gemaakt. ${ }^{103}$ Er is een schending van de artikelen 10 en $11 \mathrm{Gw}$. in zoverre de vervaltermijn voor de persoon die de afstamming opeist, kan aanvangen voor de betwiste erkenning heeft plaatsgevonden.

44.- De beslissing van het Hof verdient bijval. Het gaat hier duidelijk om een vergetelheid van de wetgever. ${ }^{104}$ Opdat de biologische vader over een daadwerkelijk vorderingsrecht zou beschikken, kan de vervaltermijn van één jaar nooit vroeger beginnen lopen dan op de dag van de opmaak van de erkenningsakte. Een wetswijziging van artikel 330, §1, vierde lid in die zin lijkt zich op te dringen. ${ }^{105}$

\section{Vertrekpunt: Termijn vangt aan voor kennis van erkenning (GwH 5 december 2013, nr. 165/2013) ${ }^{\mathbf{1 0 6}}$ - Zoals gezegd, is het tijdstip van een erkenning afhankelijk van het initiatief}

\footnotetext{
${ }^{98}$ Voor de verwekker: GwH 17 oktober 2013, nr. 139/2013, Act.dr.fam. 2014, afl. 3, 71; RTDF 2013, afl. 4, 1045, m.nt. van G. Mathieu en GwH 5 december 2013, nr. 165/2013, Act.dr fam. 2014, afl. 3, 62; T. Fam. 2014, afl.2, 39, m.nt. van A. Quirynen. Voor de 'erkenner': GwH 25 september 2014, nr. 139/2014.

${ }_{99}$ GwH 6 april 2011, nr. 54/2011, Act.dr.fam. 2011, 146, m.nt. van N. Massager; T. Fam. 2011, 93, m.nt. van G. Verschelden.

${ }^{100}$ Art. 330, §1 lid 4 BW.

${ }^{101}$ Verschelden 2011, p. 97.

102 GwH 6 april 2011, nr. 54/2011, r.o. B.2.3.

${ }^{103}$ GwH 6 april 2011, nr. 54/2011, r.o. B.3.1.

${ }^{104}$ Massager 2011, p. 135.

${ }^{105}$ Verschelden 2011, p. 100.

${ }^{106}$ GwH 5 december 2013, nr. 165/2013, Act.dr fam. 2014, afl. 3, 62; T. Fam. 2014, afl.2, 39, m.nt. van A. Quirynen.
} 
van de erkenner en bijgevolg niet vast te bepalen. Om die reden is het niet ondenkbaar dat de persoon die het vaderschap wenst te betwisten geen kennis heeft kunnen nemen van het feit dat de erkenning heeft plaatsgevonden, vooraleer de vervaltermijn is verstreken.

46.- Analoog aan de redenering in het arrest van 6 april 2011, stelt het Hof dat ook een dergelijke bepaling niet bestaanbaar is met de artikelen 10 en $11 \mathrm{Gw}$.

47.- De stelling die het Hof hier inneemt kan mijns inziens slechts gevolgd worden in zoverre het 'kennis kunnen nemen' van de erkenning strikt wordt geïnterpreteerd. Enkel indien de persoon die het vaderschap opeist redelijkerwijze geen kennis had kunnen nemen van de erkenning mag volgens mij een uitzondering worden toegestaan.

\subsection{Het EHRM}

48.- Het invoeren van termijnen is op zich niet strijdig met artikel 8 EVRM. Zulks kan immers verantwoord worden ter bescherming van de rechtszekerheid en de rust der families, evenals het belang van het kind. ${ }^{107}$ De aard van die termijn kan wel als strijdig worden beschouwd. ${ }^{108}$ Een absolute termijn die ertoe kan leiden dat een persoon slechts over een theoretisch en illusoir recht beschikt, is strijdig met artikel 8 EVRM. ${ }^{109}$

Het EHRM maakt daarbij een onderscheid tussen zaken waarbij de verzoeker niet de gelegenheid had om kennis te nemen van de feiten enerzijds, en zaken waarin hij de biologische waarheid kende of vermoedde en geen stappen ondernam binnen de wettelijke termijn anderzijds. ${ }^{110}$

\subsection{Vergelijking}

49.- In het arrest van 3 mei 2011 grijpt het Grondwettelijk Hof opnieuw systematisch terug naar de Kroon-rechtspraak, terwijl het in casu aan de houding van de eisende partij te wijten was dat de vordering niet meer kon worden behandeld. In de zaak voor het EHRM voorzag de wetgeving daarentegen in geen enkele betwistingsmogelijkheid. Het Hof heeft bijgevolg het arrest-Kroon verkeerdelijk naar analogie toegepast. In de mate dat het recht een daadwerkelijke kans voorziet om bepaalde rechten te laten gelden, is een vervaltermijn immers niet strijdig met artikel 8 EVRM.

50.- In alle daaropvolgende arresten heeft het Hof terecht zijn zienswijze aangepast. Het standpunt in het arrest van 3 februari 2011, betreffende het vorderingsrecht van het kind, heeft het Hof vooralsnog - mijns inziens onterecht - niet herzien. Dat de Belgische wetgever

\footnotetext{
107 EHRM 21 november 1984, 8777/79 (Rasmussen/Denemarken), § 41; EHRM 20 december 2007, 23890/02 (Phinikaridou/Cyprus), § 51; EHRM 6 juli 2010, 36498/05 (Backlund/Finland), § 45; EHRM 9 maart 2010, 35016/07 (Wulff/Denemarken); EHRM 18 februari 2014, 28609/08 (A.L./Polen), § 71.

${ }^{108}$ EHRM 24 november 2005, 74820/01 (Shofman/Rusland), §§ 42-46; EHRM 15 januari 2013, 7361/05 (Laakso/Finland), § 45; EHRM 29 januari 2013, 13072/05 (Röman/Finland), § 50.

109 EHRM 24 november 2005, 74820/01 (Shofman/Rusland), §§ 42-46; EHRM 20 december 2007, 23890/02 (Phinikaridou/Cyprus), §§ 64-65; EHRM 6 juli 2010 (Backlund/Finland), § 56. Zie ook Wuyts 2013, p. 511.

${ }^{110}$ EHRM 20 december 2007, 23890/02 (Phinikaridou/Cyprus), $\S \S 64-65$
} 
rekening houdt met de daadwerkelijk kennisname van het (niet-)genetische vaderschap is immers conform artikel 8 EVRM. ${ }^{111}$

\section{HET BELANG VAN HET KIND}

\subsection{Leeftijdscriterium (>1 jaar)}

51. De erkenning (GwH 16 december 2010, nr. 144/2010) ${ }^{112}$ - Opdat een man tot de erkenning van een minderjarig niet-ontvoogd kind zou kunnen overgaan, is krachtens artikel 329bis, § 2 BW steeds de toestemming nodig van de juridische moeder. Is het kind bovendien 12 jaar of ouder, dan moet hij of zij eveneens toestemmen tot de erkenning. Bij weigering wordt het verzoek voor de rechtbank gebracht. Mislukt de verplichte verzoeningspoging, dan wijst de rechter het verzoek steeds af indien vaststaat dat de verzoeker niet de biologische vader is. Is het kind op het tijdstip van indienen van het verzoek één jaar of ouder, dan kan de rechtbank de erkenning weigeren als ze kennelijk strijdig is met de belangen van het kind.

Dit alles betekent dat:

- Indien de moeder zich akkoord verklaart met de erkenning, noch de biologische werkelijkheid, noch het belang van het kind een rol spelen. De rechtbank komt niet tussen. De erkenning kan zonder meer plaatsvinden.

- Voor de erkenning van een kind jonger dan één jaar voor de rechter enkel een biologische band vereist is, ondanks de toestemmingsweigering van de moeder. Er is geen enkele opportuniteitscontrole mogelijk. De wetgever heeft in dit geval voorzien in een vermoeden dat de erkenning niet (kennelijk) strijdig is met de belangen van het kind.

- Bij toestemmingsweigering een man die genetisch niet verwant is met het kind nooit een afstammingsband zal kunnen vestigen, zelfs niet indien er een socio-affectieve band in de zin van een vader-kindrelatie bestaat en indien dit in het belang van het kind zou zijn.

De houding van de moeder (en/ of het kind) is bijgevolg determinerend (zie infra $\mathrm{nr} .87$ e.v.).

52.- De aspirant-erkenner, die met een drank- en drugprobleem worstelde en strafrechtelijk veroordeeld was voor verkrachting van de moeder tijdens de zwangerschap, wendde zich tot de rechtbank na de toestemmingsweigering tot erkenning. Het verzoek werd ingediend voor het kind één jaar was. Het bewijs van niet-biologisch vaderschap werd vervolgens niet geleverd waardoor de rechter moest oordelen dat de erkenning kon plaatsvinden.

Het Hof werd bevraagd naar de grondwettigheid van een opportuniteitscontrole bij het verzoek tot erkenning voorbehouden voor kinderen ouder dan 1 jaar.

\footnotetext{
${ }^{111}$ Zie ook Wuyts 2013, p. 518.

${ }^{112}$ GwH 16 december 2010, nr. 144/2010, Act.dr.fam. 2011, 2, m.nt. van N. Massager; RABG 2011, 833, m.nt. van E. De Maeyer en C. Vergauwen; T. Fam. 2011, 56, m.nt. van F. Swennen.
} 
53.- Het Hof overweegt dat hoewel het vaststellen van een afstammingsband in twee lijnen doorgaans in het belang is van het kind, dit niet noodzakelijk altijd het geval hoeft te zijn. ${ }^{113}$ De leeftijd van één jaar ter zake is een objectief, maar geen pertinent criterium. ${ }^{114} \mathrm{De}$ ongelijke behandeling is bijgevolg discriminerend.

54.- Werd het biologische vaderschap niet weerlegd, dan moet de rechter voortaan rekening kunnen houden met de belangen van het kind jonger dan 1 jaar bij de betekening van de dagvaarding. De bevoegdheid van de rechter blijft echter beperkt tot een marginale toetsing.

55.- Binnen de rechtsleer zijn de meningen over het arrest zeer verdeeld. Sommigen vinden dat het leeftijdscriterium in de wet had kunnen worden gehandhaafd. ${ }^{115}$ Anderen menen dat de ongrondwettigheid beter had kunnen leiden tot een gehele opheffing van de toets. ${ }^{116}$

N. GALlus en A. VAN GYSEL nemen als uitgangspunt dat een geëngageerde en verantwoordelijke vader die zich meteen (binnen het jaar) na de geboorte aandient terecht niet op zijn geschiktheid wordt beoordeeld. ${ }^{117}$ Ondanks dat, wordt in die opvatting onterecht geen rekening gehouden met het tijdstip van de ontdekking van de geboorte of van de biologische waarheid. ${ }^{118}$ Daarnaast menen deze auteurs dat het verschil in behandeling tussen het kind ouder of jonger dan één jaar minder groot is dan wordt gesteld. De controlebevoegdheid van de rechter blijft in het eerste geval immers beperkt tot een marginale toetsing. ${ }^{119}$ Gezien het arrest van 7 maart 2013 over diezelfde marginale toetsing in het onderzoek naar het vaderschap, heeft dit argument zijn geldingskracht verloren.

56.- Het leeftijdscriterium is mijns inziens zonder meer arbitrair en discriminatoir, en dus te vermijden. ${ }^{120}$ Het Hof kon dus twee kanten uit: ofwel de toets doortrekken naar alle kinderen, ofwel ze geheel schrappen. Het Hof heeft voor de eerste optie gekozen. Mijn voorkeur gaat uit naar de tweede.

Immers, noch de echtgenoot die krachtens het vaderschapsvermoeden het juridische vaderschap verwerft, ${ }^{121}$ noch de vrouw die van het kind is bevallen ${ }^{122}$ worden aan een dergelijke toets onderworpen. De vestiging van de afstammingsband gebeurt automatisch, dat is zonder enige toestemmingsvereiste, zonder controle van de biologische waarheid en zonder enige toets aan het belang van het kind. ${ }^{123}$ Het belang van het kind is evenmin aan de orde in

\footnotetext{
${ }_{113}$ GwH 16 december 2010, nr. 144/2010, r.o. B.5.

${ }^{114}$ GwH 16 december 2010, nr. 144/2010, r.o. B.6.

${ }^{115}$ Senaeve 2012a, pp. 1306-1307; Gallus \& Van Gysel 2013, pp. 392-395.

${ }^{116}$ Swennen 2013, p. 236.

117 Gallus \& Van Gysel 2013, pp. 392-395. In dezelfde zin: Senaeve 2012, 1306.

${ }^{118}$ Swennen 2011, p. 59.

${ }^{119}$ Gallus \& Van Gysel 2013, pp. 392-395.

${ }_{120}$ Melkebeek 2012, p. 142.

${ }^{121}$ Art. 315 BW.

${ }^{122}$ Art. $312, \S 1 \mathrm{BW} j^{\circ}$ art. $57,2^{\circ} \mathrm{BW}$.

${ }^{123}$ Sosson 2013, p. 101.
} 
procedures tot betwisting van het ouderschap, ${ }^{124}$ met uitzondering van de '2-in-1-vordering' van de beweerde biologische ouder. ${ }^{125}$

57.- Ik ondersteun de opvatting, zoals onder meer aangedragen door F. SWENNEN, dat elke toets aan het belang van het kind die het vestigen van een afstammingsband verhindert uit het afstammingsrecht moet worden geweerd. ${ }^{126}$ Inzake afstamming moet het belang van het kind worden toegespitst op de toekenning van een juridische staat aan een kind en niet op de uitoefening van de rechten die er het gevolg van zijn, zoals ouderlijk gezag, verblijfsrecht of onderhoudsplicht. ${ }^{127}$ De regel blijft dan dat het kind beter af is met een dubbele afstammingsband. $^{128}$

58. Het onderzoek naar het vaderschap (GwH 3 mei 2012, nr. 61/2012) ${ }^{\mathbf{1 2 9}}$ - Artikel 322, lid $1 \mathrm{BW}$ bepaalt dat de vordering tot gerechtelijke vaststelling van het vaderschap enkel ontvankelijk kan worden verklaard indien het vaderschap nog niet vaststaat krachtens het vaderschapsvermoeden of de erkenning. Gelijkaardig aan de toestemmingsweigering tot de vaderlijke erkenning bepaalt artikel 332quinquies BW dat de moeder en het kind ouder dan 12 over een recht van verzet beschikken tegen de gerechtelijke vaststelling van het vaderschap. Ook hier betekent het verzet geen definitieve halt aan het vaderschap maar lokt het een controle door de rechter uit.

59.- Heeft het kind al een juridische vader dan moet dit vaderschap eerst worden betwist. De beweerde biologische vader kan het vaderschap van de echtgenoot enkel betwisten indien zijn eigen vaderschap vervolgens kan komen vast te staan. ${ }^{130}$ Vereist is bijgevolg dat zowel aan de voorwaarden van artikel $318 \mathrm{BW}$, als aan die van artikel 332quinquies $\mathrm{BW}$, is voldaan.

In hoofdlijnen:

- De vordering tot betwisting van het vaderschap van de echtgenoot werd tijdig ingesteld, dat is voor de beweerde biologische vader binnen het jaar na de ontdekking van het feit dat hij het kind heeft verwekt; ${ }^{131}$

- Het kind heeft geen bezit van staat ten aanzien van de echtgenoot; ${ }^{132,133}$

- Er kan niet worden bewezen dat de persoon die het vaderschap opeist niet de biologische vader van het kind is; ${ }^{134}$

- De vaststelling van de afstammingsband met de vermeende biologische vader is niet kennelijk strijdig met het belang van het kind ouder dan 1 jaar. ${ }^{135}$

\footnotetext{
${ }^{124}$ Artt. 312, § 2, 318, §§ 1-3 en 330, §§ 1-2 BW.

${ }^{125}$ Artt. 318, § 5 en 330, §3 BW en zie Senaeve 2012a, pp. 1306-1307.

${ }^{126}$ Swennen 2011c, pp. 60-61; De Maeyer \& Vergauwen 2011, p. 889.

${ }^{127}$ In die zin: Luik 7 juni 2010, 2009/RG/668 en 2009/RG/1216, onuitg. (www.legalworld.be); Rb. Brussel (12 ${ }^{\mathrm{e}} \mathrm{k}$.) 23 januari 2008, JLMB 2008, 1067: De Maeyer \& Vergauwen 2011, p. 888.

${ }_{128}$ Zie ook Parl. St. Kamer, 2003-2004, DOC 51-0597/001, 9-10, zoals aangehaald door het Hof in r.o. B.4.

${ }^{129}$ GwH 3 mei 2012, nr. 61/2012, T. Fam. 2013, 90, m.nt. van F. Swennen.

${ }^{130}$ Art. $318, \S 5 \mathrm{BW}$.

${ }^{131}$ Art. 318, § 2, lid 1 BW.

${ }^{132}$ Art. $318, \S 1 \mathrm{BW}$.

${ }^{133}$ In het licht van de rechtspraak van de Grondwettelijk Hof dient deze voorwaarde evenwel genuanceerd te worden. Zie GwH 3 februari 2011, nr. 20/2011; GwH 9 juli 2013, nr. 105/2013 en GwH 7 november 2013, nr. 147/2013.

${ }^{134}$ Art. 332quinquies, § 2, lid $1 \mathrm{BW}$.
} 
Ook hier gaat het dus slechts om een marginale toetsing en enkel voor het kind ouder dan één jaar.

60.- Een man, van wie de moeder had toegegeven dat hij de biologische vader van haar kind was, wilde het vaderschap van haar echtgenoot betwisten en zijn eigen vaderschap doen vaststellen. Het vaderschap van de echtgenoot werd niet bevestigd door bezit van staat, de biologische waarheid stond niet ter discussie en ten tijde van de betekening van de dagvaarding was het kind nog geen jaar oud, waardoor geen rechterlijke toets aan het belang van het kind kon worden uitgevoerd. Wederom werd een prejudiciële vraag gesteld over het leeftijdscriterium van 1 jaar om een toetsing aan het belang van het kind door de rechter uit te lokken.

61.- Gelet op het arrest van 16 december 2010 bleek het antwoord op die vraag evident. Het Hof besloot ook hier tot een schending op grond van dezelfde motieven. ${ }^{136}$

62.- Stelt de beweerde biologische vader een vordering in tot betwisting van het vaderschap van de echtgenoot teneinde zijn eigen vaderschap te doen vaststellen, dan zal bij verzet van de moeder, de rechter ook de belangen van het kind jonger dan 1 jaar marginaal kunnen toetsen. Het dictum is echter beperkt tot de vordering van de beweerde biologische vader waardoor, gezien het verbod van analogie, het arrest niet kan worden toegepast op een andere rechtsvraag. Voor de situatie waarin het kind jonger dan 1 jaar, vertegenwoordigd door een voogd ad hoc, zich tegen de gerechtelijke vaststelling van het vaderschap verzet, zal een nieuwe prejudiciële vraag moeten worden gesteld.

63.- Mutatis mutandis gelden voor het overige dezelfde bedenkingen als uiteengezet in randnummers 55 tot en met 57.

\subsection{De toetsingsbevoegdheid}

64. Slechts een marginale toetsing (GwH 7 maart 2013, nr. 30/2013) ${ }^{137}$ - Zoals vermeld, kan de rechter de vordering tot onderzoek van het vaderschap afwijzen indien de vaststelling van het biologisch juiste vaderschap kennelijk strijdig is met het belang van het kind. Dit houdt in dat enkel een ernstig gevaar voor het kind het vaderschap van de biologische vader kan verhinderen. ${ }^{138}$

65.- Een vrouw bevalt op 24 januari 2004 van een zoon, in overspel verwekt. Krachtens het vaderschapsvermoeden wordt haar echtgenoot de vader. Bij de inwerkingtreding van de wet van 1 juli 2006, ${ }^{139}$ leidde de biologische vader de zogenaamde '2-in-1-vordering' in, op basis

\footnotetext{
${ }^{135}$ Art. 332quinquies, § 2, lid 1 BW.

${ }^{136}$ R.o. B.6-B.8.

${ }^{137}$ GwH 7 maart 2013, nr. 30/2013, Act.dr.fam. 2013, 76, m.nt. van N. Gallus; RTDF 2013, 789, m.nt. van M. Demaret; T. Fam. 2013, 232, m.nt. van F. Swennen; TJK 2013, 151, m.nt. van E. Ignovska en G. Verschelden.

${ }^{138}$ Verschelden 2013, p. 5.

${ }^{139}$ Wet 1 juli 2006 tot wijziging van de bepalingen van het Burgerlijk Wetboek met betrekking tot de vaststelling van de afstamming en de gevolgen ervan, BS 29 december 2006.
} 
van artikel 318, $\S 5 \mathrm{BW}$. In hoger beroep werd het bezit van staat ten aanzien van de echtgenoot "dubbelzinnig" geacht. Dat de vaststelling van het vaderschap van de eiser kennelijk strijdig zou zijn met het belang van het kind werd niet bewezen.

Het echtpaar, overtuigd dat een ruimere toetsingsbevoegdheid tot een andere beslissing zou hebben geleid, trok daarop naar het Hof van Cassatie. Een stevig verankerde afstamming opgeven enkel omdat er geen ernstig gevaar voor het kind kon worden gevonden in het vaderschap van de biologische vader vonden zij te verregaand. Artikel 332quinquies, §2, lid 1 BW laat de rechter echter niet toe een beoordeling in concreto te maken.

66.- De prejudiciële vraag van het Hof van Cassatie had betrekking op de aard van de toetsingsbevoegdheid van de rechter bij het onderzoek naar het vaderschap (of moederschap). Daar waar artikel 332quinquies, §2, lid 1 BW slechts een marginale toetsing aan het belang van het kind voorschrijft, vereist artikel 22bis, lid $4 \mathrm{Gw}$. dat dit belang de eerste overweging is bij elke beslissing die het kind aangaat.

Verwijzend naar de bewoordingen en geest van artikel 22bis, lid 4 Gw. (in samenlezing met artikel 3.1 Kinderrechtenverdrag) en de rechtspraak van het EHRM (zie infra 75 e.v.) ${ }^{140}$, besluit het Hof dan ook tot een schending.

67.- In het vorige arrest besloot het Hof reeds tot een schending van artikel 332quinquies BW op het punt van het leeftijdscriterium van één jaar om een marginale toetsing te kunnen doorvoeren. $\mathrm{Nu}$ wordt ook die marginale toetsing geheel achterwege gelaten. Uitgangspunt is niet langer dat het belang van het kind het onderspit moet delven ten voordele van de biologische werkelijkheid. ${ }^{141}$ Naar de toekomst toe zal er bij het onderzoek naar het vaderschap na verzet telkens een concrete belangenafweging moeten plaatsvinden, waarbij het belang van het kind een voorkeursbehandeling geniet. ${ }^{142}$ Het belang van het kind krijgt aldus een primordiaal karakter. Let wel: primordiaal, niet absoluut. Het Hof wijst er met name uitdrukkelijk op dat er plaats blijft voor de inachtneming van alle belangen in het geding. ${ }^{143}$ Wat dit laatste betreft zijn er bij het arrest van 20 maart 2014 wel enkele vraagtekens te plaatsen (zie infra 69 e.v.).

68.- De rechter zal naar de toekomst toe de blanco norm van het 'het belang van het kind' moeten concretiseren en personaliseren bij het onderzoek naar het vaderschap. ${ }^{144}$ Het Hof dwingt de rechter in een actievere rol door hem de mogelijkheid te geven om van een absolute regel af te wijken indien deze in een concreet geval onwenselijke gevolgen met zich meebrengt. Op deze manier zet het Hof de lijn verder van individualisering van het afstammingsrecht. $^{145}$

\footnotetext{
${ }^{140}$ Deze arresten handelen echter niet over het onderzoek naar het vaderschap, maar over ouderlijk gezag, contact en adoptie, en zijn volgens sommigen dus slechts naar analogie toepasbaar: Demaret 2013, p. 804; Ignovska \& Verschelden 2013, p. 160.

${ }^{141}$ Verschelden 2005b, p. 172.

${ }^{142}$ Verschelden 2013, pp. 4-5.

${ }^{143}$ GwH 7 maart 2013, nr. 30/2013, r.o. B.10.

${ }^{144}$ Bijv. Luik 16 december 2013, 2013/RG/581, onuitg.

${ }^{145}$ Gallus \& Van Gysel 2013, p. 399.
} 
69.- Waar de vorige arresten al op kritiek konden rekenen, geldt dit eens te meer voor de verruiming van de toetsingsbevoegdheid van de rechter. ${ }^{146}$ Allereerst kan aan artikel 22 bis Gw., net als aan artikel 3.1 Kinderrechtenverdrag, ${ }^{147}$ geen directe werking worden verleend. ${ }^{148}$ Gevolg is dat de wetgever kan beslissen om ervan af te wijken via specifieke bepalingen. Er anders over oordelen zou betekenen dat elk wetsartikel dat een beslissing vergt met betrekking tot het kind, in zijn belang terzijde zou kunnen worden geschoven door de rechter. ${ }^{149}$ Een dergelijke beoordelingsmarge is inzake afstamming absoluut niet wenselijk. ${ }^{150}$

Ten tweede had de wetgever duidelijk de bedoeling om bij het onderzoek naar het vaderschap de biologische band te laten primeren door slechts een beperkte toetsing toe te laten. ${ }^{151}$ Een afstammingsband die aan de biologische realiteit beantwoordt, wordt immers vermoed in het belang van het kind te zijn. Een uitgebreide toetsing is dan niet meer nodig. ${ }^{152}$ Dat laatste is bij uitstek voer voor discussie. Een discussie die het Hof uit de weg gaat in zijn beoordeling; aan het evenwicht dat de wetgever voor ogen had tussen de biologische en socio-affectieve realiteit wordt voorbijgegaan. Zeker is dat met dit arrest artikel 332quinquies BW in zijn essentie is aangepast zonder enig wetgevend optreden.

Ten derde kan volgens mij, gezien de context van het arrest, de doelstelling van de concrete belangenafweging in vraag worden gesteld. Wordt enkel gekeken naar de verhouding tussen biologische vader en kind (het bestaande vaderschap als doorbroken beschouwend), dan is mijns inziens hoogstens een marginale toetsing verantwoord. Bij voorkeur zou de afstammingsband zelfs (quasi) automatisch kunnen worden vastgesteld. ${ }^{153}$ Wordt daarentegen beoogt via deze weg de deur opnieuw te openen voor het vaderschap van de echtgenoot en een "keuze tussen vaders" mogelijk te maken, ${ }^{154}$ dan meen ik dat de discussie verplaatst dient te worden naar het niveau van de betwisting. Leidt de huidige invulling van bezit van staat tot onbillijke situaties voor het kind, dan is wellicht een ruimere toetsing nodig. Op die manier blijft de situatie waarin er nog geen vaderschapsband is vastgesteld buiten schot. ${ }^{155}$

De persoon die het vaderschap betwist en tegelijk opeist mag niet, nadat de tegenpartij reeds gefaald heeft het bezit van staat te bewijzen én de biologische band te weerleggen, nog via een derde achterpoortje het vaderschap worden ontzegd.

Ten vierde wordt de kloof met automatische vaststellingen van het ouderschap - zijnde het moederschap op basis van de geboorteakte en het vaderschap van de echtgenoot - alsmaar

\footnotetext{
${ }^{146}$ Verschelden 2013b, pp. 98-99; Gallus 2013b, p. 81. A contrario: Demaret 2013, p. 807; Stevens 2001 pp. 4-5, nr. 223.

${ }^{147}$ Cass. 4 november 1999, $R W$ 2000-01, 232, m.nt. van A. Vandaele.

${ }^{148}$ Parl.St.Kamer 2007-08, nr 52-0175/001,6 en nr. 52-0175/005,13, 31-32. Zie ook RvS 29 mei 2013, TBP 2013, afl. 10, 637; Gevers \& Godfroid 2013, p. 5.

${ }^{149}$ Verschelden 2013b, p. 99.

${ }^{150}$ Gallus 2013a, p. 1368.

${ }^{151}$ Swennen 2007, p. 219, nr. 431.

${ }^{152}$ Swennen 2011 c, p. 60.

${ }^{153}$ Mits het natuurlijk niet gaat om een meerderjarig of ontvoogd minderjarig kind; in welk geval er een absoluut vetorecht bestaat (art. 332quinquies, §1 BW).

${ }^{154}$ Sosson 2013a, p.110.

${ }^{155}$ Gallus 2013a, p. 1358.
} 
groter. ${ }^{156}$ Hetzelfde geldt voor de erkenning met instemming van de moeder en de betwisting van het vaderschap. ${ }^{157}$ In gevallen waarin men genoopt is zijn toevlucht te nemen tot een gerechtelijke procedure om een afstammingsband tot stand te brengen, kan een verregaande screening mijns inziens moeilijk worden verantwoord.

J. SosSON onderscheidt terecht drie verschillende discriminaties, namelijk tussen (1) moeders en vaders; (2) huwelijks en buitenhuwelijks vaderschap; en (3) mannen die hun vaderschap willen doen vestigen en mannen die 'gedwongen' worden door moeder of kind. In dat laatste geval wordt er, bij gebrek aan verzet, immers helemaal geen toets doorgevoerd. ${ }^{158}$

Tot slot is er qua uitwerking tegen wil en dank een hybride situatie gecreëerd met betrekking tot de toetsingsbevoegdheid aan het belang van het kind in afstammingskwesties. Ook inzake de erkenning ${ }^{159}$ is immers sprake van dezelfde marginale toetsing (zie supra 53 en 54). ${ }^{160}$ Voor uitsluitsel omtrent deze bepalingen is het wachten op een nieuwe prejudiciële vraag. Omdat de rechtsgrond verschillend is, kan het arrest van 7 maart 2013 niet zonder meer naar analogie worden toegepast. ${ }^{161}$ Wil het Hof echter consequent zijn, dan zal het ook in die gevallen moeten besluiten tot een strijdigheid.

70. Enkel aan het belang van het kind (GwH 20 maart 2014, nr. 48/2014) ${ }^{162}$ - Artikel 332 quinquies BW bepaalt dat de vordering tot gerechtelijke vaststelling van het vaderschap moet worden afgewezen als:

- de moeder of het kind ouder dan 12 zich daartegen verzet; en

- de vaststelling van de afstamming kennelijk strijdig is met het belang van het kind ouder dan 1 jaar, in die zin dat dit een ernstig gevaar zou opleveren voor het kind.

71.- Het Grondwettelijk Hof heeft inmiddels in twee arresten ${ }^{163}$ grondig ingegrepen in de toets aan het belang van het kind. Voortaan moet de rechter een concrete belangenafweging maken, waarbij het belang van het kind primeert, ongeacht de leeftijd, maar moeten tevens de belangen van alle andere partijen in het afstammingsgeding in overweging worden genomen. ${ }^{164}$

Daar waar het Hof in het arrest van 7 maart 2013 een in abstracto voorrangspositie van het belang van het kind lijkt te schuwen, neemt het in het volgende arrest een geheel ander standpunt in.

72.- In deze zaak ging de vordering tot gerechtelijke vaststelling van het vaderschap uit van een 44-jarig kind. In een eerdere procedure had het kind al succesvol het vaderschap van zijn

\footnotetext{
${ }^{156}$ Verschelden 2013b, p. 99.

${ }^{157}$ Gallus 2013a, p. 1357.

${ }^{158}$ Sosson 2013a, pp. 108-110.

${ }_{159}$ Art. 329 bis, § 2, lid 3 en $\S 3$, lid 5 BW.

${ }^{160}$ Demaret 2013, p. 806.

${ }^{161}$ Verschelden 2013a, p. 34.

${ }^{162}$ GwH 20 maart 2014, nr. 48/2014, RTDF 2014, afl. 2, 389; RW 2013-14, afl. 33, 1320.

${ }^{163}$ GwH 3 mei 2012, nr. 61/2012 en GwH 7 maart 2013, nr. 30/2013.

${ }^{164}$ Swennen 2013b, p. 236.
} 
juridische vader betwist. Ter bevestiging van het vaderschap van een andere man, inmiddels overleden, vorderde hij een DNA-onderzoek, maar stuitte op verzet van de rechtsopvolgers. Zij meenden, verwijzend naar het arrest van 7 maart 2013, dat het belang van het kind niet op absolute wijze mag voorgaan op de andere belangen in het geding. Vermeld worden onder meer (1) de persoonlijke en patrimoniale rechten van de verweerders; (2) het algemeen belang van de rechtszekerheid van de familiebanden en de rust der families; (3) het feit dat de vordering heel laat wordt ingesteld; en (4) het gebrek aan een socio-affectieve band met hun rechtsvoorganger, evenals tussen de eiser en de verweerders. ${ }^{165}$

73.- Het Hof stelt dat bij het uitwerken van een regeling inzake afstamming de wetgever de bevoegde overheid in beginsel de mogelijkheid moet bieden om in concreto een afweging te maken tussen alle belangen. Dit beginsel heeft echter geen absoluut karakter. De wetgever is aldus binnen zijn appreciatiemarge gebleven door te oordelen dat "in een gerechtelijke procedure tot vaststelling van de afstamming het recht van eenieder op vaststelling van zijn afstamming de overhand dient te krijgen op het belang, in het algemeen, van de rust van de families en de rechtszekerheid van de familiale banden en op het recht, in het bijzonder, van de verwanten van de biologische vader om hun privé- en gezinsleven niet verstoord te zien" ${ }^{\text {}} 66$. Er wordt geen schending vastgesteld.

74.- De rechter moet bij het onderzoek naar het vaderschap telkens in concreto kijken of het belang van het kind gediend is met de juridische vaststelling van het biologisch vaderschap. De andere belangen in het geding blijken dan toch ondergeschikt.

75.- Het Hof lijkt het belang van het kind verder op een voetstuk te plaatsen. De wetgever mag in abstracto het belang van het kind steeds laten primeren op elk ander belang wanneer het gaat om een gerechtelijke vaststelling van de afstamming die door het kind is ingesteld. Op die manier, mijns inziens terecht, wordt dan toch een halt toegeroepen aan de verdere individualisering van het afstammingsrecht. Desondanks herneem ik het standpunt dat ook een toets aan het belang van het kind overbodig blijft.

\subsection{Het EHRM}

76.- In de zaak-Yousef heeft het EHRM een duidelijk standpunt ingenomen. De verzoeker wilde het kind erkennen, maar had niet de toestemming van de overleden moeder bekomen, en bijgevolg ook niet die van de rechter. Het EHRM stelde dat: "in judicial decisions where the rights under Article 8 of parents and those of a child were at stake, the child's rights must be the paramount consideration. If any balancing of interests was necessary, the interests of the child must prevail." 167 [onderstreping: ES]

\footnotetext{
${ }^{165}$ Aangehaald door eisers in A.1. van het arrest.

${ }^{166}$ GwH 20 maart 2014, nr. 48/2014, r.o. B.10.

${ }^{167}$ EHRM 5 november 2002, 33711/96 (Yousef/Nederland), § 73.
} 
Inzake afstamming primeert het belang van het kind altijd op alle andere belangen. Echter uit de voorwaardelijke formulering van de laatste zin kan worden afgeleid dat niet steeds een belangenafweging in concreto vereist is. ${ }^{168}$

77.- Het recentere arrest-Ahrens lijkt echter in de tegenovergestelde richting te wijzen: "Consideration of what lies in the best interests of the child concerned is of paramount importance in every case of this kind." 169 [onderstreping: ES]

In elke zaak dient het belang van het kind de belangrijkste overweging te zijn.

\subsection{Vergelijking}

78.- Het Grondwettelijk Hof beslist terecht dat een belangenafweging in concreto met een voorrangspositie voor het kind in overeenstemming is met de rechtspraak van het EHRM. Echter niet alle arresten die worden aangehaald zijn even relevant. Hoewel telkens de nadruk wordt gelegd op het belang van het kind gaat het niet overwegend om de context van afstamming, ${ }^{170}$ maar onder andere om het recht om de terugkeer te vorderen van het kind na een internationale kinderontvoering, ${ }^{171}$ een recht op contact, ${ }^{172}$ een recht om het ouderlijk gezag uit te oefenen ${ }^{173}$ en een recht op erkenning van een volle adoptie ${ }^{174}$. Zulks geldt evenwel niet voor de arresten-Yousef (erkenning na toestemmingsweigering) en Ahrens (betwisting buitenhuwelijkse afstamming). Een toepassing naar analogie is mijns inziens verantwoord.

79.- De stelling dat een toetsing geheel achterwege kan worden gelaten, lijkt bijgevolg moeilijk verdedigbaar in het licht van de rechtspraak van het EHRM en de duidelijke bewoordingen van artikel 22bis, lid 4 van de grondwet.

\section{VERBODEN AFSTAMMING: INCEST}

80.- Volgens artikel $325 \mathrm{BW}$ is het onderzoek naar het vaderschap onontvankelijk wanneer uit het vonnis een huwelijksbeletsel tussen de vermeende vader en de moeder blijkt, waarvoor de Koning geen ontheffing kan verlenen.

81. GwH 9 augustus 2012, nr. 103/2012 ${ }^{175}$ - Het Hof oordeelde dat artikel 325 BW strijdig is met artikelen 10 en $11 \mathrm{Gw}$., in samenhang met 8 EVRM en met artikelen 3, lid 1, en 7, lid 1 IVRK. Het in abstracto verbieden van de mogelijkheid de dubbele afstammingsband vast te

\footnotetext{
${ }^{168}$ In dezelfde zin: Swennen 2011c, p. 60.

${ }^{169}$ EHRM 22 maart 2012, 45071/09 (Ahrens/Duitsland), § 63.

${ }^{170}$ Ignovska \& Verschelden 2013, pp. 160-161.

${ }^{171}$ EHRM 26 juni 2003, 48206/99 (Maire/Portugal) en EHRM 6 juni 2010, 41615/07 (Neulinger en Shuruk/Zwitserland). Zie ook EHRM 26 november 2013, 27853/09 (X/Letland), §96.

172 EHRM 8 juli 2003, 31871/96 (Sommerfeld/Duitsland) en EHRM 26 februari 2004, 74969/01 (Görgülü/Duitsland).

${ }^{173}$ EHRM 26 februari 2004, 74969/01 (Görgülü/Duitsland).

${ }_{175}^{174}$ EHRM 28 juni 2007, 76240/01 (Wagner en J.M.W.L./Luxemburg).

${ }^{175}$ GwH 9 augustus 2012, nr. 103/2012, Act.dr.fam. 2012, 150, m.nt. van A.-C. Van Gysel; JDJ. 2012, 35, m.nt. van G. Mathieu en A. Rasson; JLMB 2011, 1281, m.nt. van P. Martens; RTDF 2013, 204, m.nt. van Y.-H. Leleu en R. Sauveur; T. Fam. 2012, m.nt. van T. Wuyts.
} 
stellen, verhindert de mogelijkheid de concrete belangen van dat kind in overweging te nemen. Het incestueuze kind wordt aldus benadeeld ten opzichte van andere kinderen. ${ }^{176}$

82.- In geval van incest zal het vaststellen van een dubbele afstamming bij het onderzoek naar het vaderschap in de toekomst mogelijk zijn als dit in het belang is van het kind. Voor de andere gevallen waar het incestverbod een absolute hinderpaal vormt, is het wachten op een nieuwe prejudiciële vraag. ${ }^{177}$

83.- Hoewel het verbod op incest een maatschappelijk ingebed en legitiem doel (het ontmoedigen van bloedschennige relaties), draagt het verbod op dubbele afstamming hier niet toe bij. Het hebben van kinderen betekent immers dat deze relatie al bestaat en het ontnemen van de mogelijkheid om de afstamming te vestigen, benadeelt dus de enige persoon die geen verantwoordelijkheid draagt, het kind. ${ }^{178}$ Vermits de dubbelzijdige vestiging verboden is en het moederschap overwegend automatisch komt vast te staan, wordt bovendien het vaderschap onterecht geviseerd. Nochtans zijn moeder en vader in principe gelijkelijk 'schuldig'. Tot slot wordt incest op het niveau van de huwelijksbeletsels onvoldoende consequent 'bestraft' om een verbod inzake afstamming in stand te houden: enkel in rechte lijn en tussen (half)broers en (half)zussen bestaat thans nog een absoluut beletsel. ${ }^{179}$ Een verbod tot vestiging van de afstamming is bijgevolg discriminerend.

84.- Tot op heden heeft het EHRM zich niet uitgesproken over de verenigbaarheid van een dergelijk afstammingsverbod met artikel 8 EVRM. ${ }^{180}$

85.- Waar het Grondwettelijk Hof in de vorige arresten de toets aan het belang van het kind heeft uitgebreid, creëert het hier een nieuwe toetsingsmogelijkheid. ${ }^{181}$ Uitgangspunt is ook hier dat de vestiging van het biologisch vaderschap de regel behoort te zijn, eventueel met uitschakeling van bepaalde rechtsgevolgen. ${ }^{182}$

86.- Op dezelfde wijze moet de 'exceptie van verkrachting' ${ }^{183}$ tegen het licht gehouden worden. Ook deze regel bevat tal van discriminaties die strijdig zijn met het belang van het kind. $^{184}$

\section{TUSSENBESLUIT}

87.- Indien nog geen vaderschap werd vastgesteld, dan wordt best het biologisch vaderschap quasi automatisch gevestigd. Is er wel al een gevestigd vaderschap dan dient de band voldoende beschermenswaardig te zijn om het te halen van de biologie. Bezit van staat als

\footnotetext{
${ }^{176}$ R.o. B.8.1.-B.9.

${ }^{177}$ Zie uitgebreid: Wuyts 2012b, pp. 225-226.

${ }_{178}$ R.o. B.8.2 en B.8.3.

${ }^{179}$ Mathieu \& Rasson 2012, p. 29.

${ }^{180}$ Een strafrechtelijke sanctie valt in elk geval onder de appreciatiemarge van de lidstaten: Zie EHRM 12 april 2012 , 43547/08 (Stübing/Duitsland), §§ 63-67.

${ }^{181}$ Sosson 2013a, pp. 112-113.

182 Leleu \& Sauveur 2013, p. 218.

${ }^{183}$ Art. 329bis, § 2, lid 4 BW en 332quinquies, § 4 BW.

${ }^{184}$ Swennen 2014, p. 348.
} 
grond van niet-ontvankelijkheid is onvoldoende geschikt om deze afweging te maken. Enkel in dit geval is mijns inziens een afweging in concreto verantwoord. Doorstaat de band de toets niet, dan geldt het eerste uitgangspunt: het biologisch vaderschap wordt gevestigd.

\section{PRO MEMORIE: 'MOTHER KNOWS BEST?'}

88.- Doorheen het vaderlijke afstammingsrecht bekleedt de moeder van het kind een cruciale rol. Zij is in staat om het vaderschap 'te maken of te kraken'.

89.- Om te beginnen heeft een vrouw als enige zeggenschap over het lot van de zwangerschap. Als zij besluit om een abortus te ondergaan of om het kind dat het resultaat was van een one night stand te houden, heeft de verwekker hier niets tegenin te brengen. Zijn eventuele vaderschapswens is ondergeschikt aan het keuzerecht van de vrouw om al dan niet moeder te worden. Hetzelfde kan gezegd worden over het gebruik van contraceptiva. ${ }^{185}$

90.- De afstammingsband met de moeder wordt in de regel automatisch gevestigd door het loutere feit van de bevalling. ${ }^{186}$ Gevallen waarbij het moederschap pas na een erkenning of gerechtelijk onderzoek komt vast te staan, zijn hoogst uitzonderlijk. ${ }^{187}$

91. - Anders dan bij een bevalling is de biologische werkelijkheid in relatie tot de man, i.e. het verwekkerschap, minder gemakkelijk te achterhalen. ${ }^{188}$ Ook al steunt het afstammingsrecht principieel op biologische banden, ${ }^{189}$ er kan niet van iedere man verwacht worden dat hij bij de aangifte van geboorte een sluitende DNA-test kan voorleggen. ${ }^{190}$ Vandaar dat de wetgever in beginsel heeft geopteerd voor een ander aanknopingspunt: de (huwelijkse) relatie met de moeder. ${ }^{191}$ Via de vaderschapsregel wordt de echtgenoot van de moeder automatisch aangeduid als juridische vader, met alle gevolgen van dien.

Dit betekent dat de moeder doorgaans als enige absolute zekerheid heeft over de identiteit van de verwekker van haar kind ${ }^{192}$ en zo een incorrecte afstammingsband in de hand kan werken, hetzij door te trouwen met een man van wie ze weet dat hij de vader niet kan zijn, hetzij door niet te scheiden van een echtgenoot die het kind niet heeft verwekt. Door het aanhouden van een relatie ontwikkelt zich een vader-kindrelatie. En zo ontstaat een bezit van staat in hoofde van de echtgenoot ${ }^{193}$ met alle gevolgen van dien.

92.- Het wettelijk vaderschapsvermoeden werd nog niet doorgetrokken naar andere samenlevingsvormen, ${ }^{194}$ maar ook bij de vaderlijke erkenning of bij een gerechtelijk

\footnotetext{
${ }^{185}$ Meulders-Klein 2008, pp. 3-5.

${ }^{186}$ Verschelden 2007 b, p. 67.

${ }^{187}$ Gallus \& Van Gysel 2013, p. 393.

${ }^{188}$ Casman 2008, p. 119.

${ }^{189}$ Swennen 2014, p. 336

${ }^{190}$ Gerlo 2002, p. 104.

191 Art. 213 BW: op grond van hun getrouwheidsverplichting wordt van echtgenoten verwacht dat zij seksuele relaties onderhouden. Zie ook Heyvaert 1979, p. 745.

${ }^{192}$ Wuyts 2013, p. 380.

${ }^{193}$ Art. 324, leden 1 en 2 BW.

${ }^{194}$ Verschelden $2007 \mathrm{c} / 08$, p. 342.
} 
onderzoek naar het vaderschap heeft de moeder een vinger in de pap te brokken. Opdat een man zou kunnen erkennen, is haar toestemming immers vereist. Een weigering leidt tot een gerechtelijke procedure, waarbij de rechter marginaal kan toetsen of het vestigen van de afstammingsband wel in het belang van het kind is. ${ }^{195}$ Bij het gerechtelijk onderzoek heeft de moeder het recht om verzet aan te tekenen tegen de vaststelling van een nieuwe vaderlijke afstammingsband. Dit verzetsecht is evenwel geen vetorecht en lokt een volle rechterlijke toetsing uit. ${ }^{196}$ Los van dit recht tot verzet is de moeder bovendien ook zelf vorderingsgerechtigde, ${ }^{197}$ waardoor ze het vaderschap van de verwekker zelfs tegen diens wil in kan laten vestigen.

93.- Deze bevoorrechte (rechts)positie van de moeder vindt haar oorsprong in de traditionele invulling van de moederrol in onze samenleving. Toch is bij de uitoefening van de zorgfunctie het geslacht van de voornaamste ouder, de primary caretaker, ${ }^{198}$ minder doorslaggevend dan gedacht. ${ }^{199}$ Niets wijst erop dat een vader minder geschikt is om deze functie uit te oefenen. Nochtans werd in het recht het uitgangspunt behouden dat een moeder steeds het best geplaatst is om een kind op te voeden, ${ }^{200}$ terwijl er evengoed drugverslaafde of mishandelende, kortom ongeschikte moeders bestaan. Mater semper certa ergo mater semper bona ${ }^{201}$

\footnotetext{
${ }^{195}$ Voor een korte samenvatting van de procedure voor de rechtbank: Verschelden 2007a, p. 148.

${ }^{196}$ Art. 322quinquies $\S 2 \mathrm{BW}$.

${ }^{197}$ Art. 332ter, lid $1 \mathrm{BW}$.

${ }^{198}$ Harris \& Butterwort 2002, p. 134.

${ }^{199}$ Bereswill, Scheiwe \& Wolde 2006, p. 8.

${ }^{200}$ Schwenzer 2007, p. 13

${ }^{201}$ Gallus \& Van Gysel 2013, p. 395.
} 


\section{- DEEL II. - \\ OUDERLIJK GEZAG}

\section{GEEN ‘VADERLIJK’ GEZAG}

\section{ALGEMEEN}

94.- Eenmaal het juridisch vaderschap is vastgesteld, rest ons de vraag wat dit vaderschap inhoudelijk betekent. Welke rol is naar Belgisch recht weggelegd voor de wettelijke vaderfiguur?

Een vader - en bij uitbreiding een ouder - dient allereerst in te staan voor de opvoeding van zijn kinderen. Via het bijbrengen van normen en waarden moet erop worden toegezien dat zij opgroeien tot zelfstandige volwassenen en hun plek vinden binnen het rechtsverkeer. Deze doelstelling wordt mede verwezenlijkt via de figuur van het ouderlijk gezag. Dit gezagsrecht staat de lege lata enkel open voor de juridische ouders. ${ }^{202}$

95.- Bij de invoering van het BW in 1804 was het de vader die als gezinshoofd zijn vaderlijke macht uitoefende, ook al waren naar de letter van de wet beide ouders titularis van het ouderlijk gezag. Na de wet van 8 april 1965 was er sprake van de ouderlijke macht, waarbij de ouders samen optraden, zij het nog steeds met een doorslaggevende stem voor de vader in geval van onenigheid. ${ }^{203}$ Ouders treden vandaag in het rechtsverkeer op als gelijken, met dezelfde - geslachtsneutrale - bevoegdheden. Van een specifiek vaderlijk gezag is geen sprake meer, beide oorspronkelijke ouders zijn titularis van het ouderlijk gezag en dit tot de meerderjarigheid ${ }^{204}$ van het kind of tot een eventuele ontzetting. ${ }^{205}$

96.- Het ouderlijk gezag is een dynamisch concept. Naarmate het kind ouder wordt, evolueert de wijze van uitoefening steeds meer van leiding over het kind naar begeleiding van de jongvolwassene. Ouders hebben in het opvoedingsproces niet enkel rechten, maar ook plichten. Vandaar dat steeds meer wordt gesproken van 'ouderlijke verantwoordelijkheden'. ${ }^{206}$

\section{BEVOEGDHEDEN}

97.- Inhoudelijk bestaat dit ouderlijk gezag uit een viertal componenten: ${ }^{207}$

\section{a) Beslissingsrecht met betrekking tot de staat van persoon van het kind}

\footnotetext{
${ }^{202}$ Antokolskaia \& Verschelden 2012, pp. 163-176.

${ }^{203}$ Wet 8 april 1965 betreffende de jeugdbescherming, het ten laste nemen van minderjarigen die een als misdrijf omschreven feit hebben gepleegd en het herstel van de door dit feit veroorzaakte schade, BS 15 april 1965 (hierna: JBW).

${ }^{204}$ Art. 372 BW.

${ }^{205}$ Art 32 JBW.

${ }^{206}$ Wuyts 2013, p. 921.

${ }^{207}$ Swennen 2014, pp. 403-406.
} 
Deze bevoegdheid heeft te maken met het vaststellen of wijzigen van de staat van het kind, bijvoorbeeld het instemmen met het huwelijk of met de erkenning door de andere ouder. Dit aspect van het ouderlijk gezag wordt principieel gezamenlijk uitgeoefend.

\section{b) Het opvoedingsrecht of recht van juridische bewaring}

Het betreft hier de bevoegdheid om beslissingen te nemen omtrent fundamentele punten binnen de opvoeding. In de wet worden expliciet genoemd: gezondheid, opleiding, ontspanning en levensbeschouwelijke keuzes. ${ }^{208}$

\section{c) Recht op persoonlijk contact, gekoppeld aan een recht op informatie}

Dit recht wordt indien nodig waargenomen via een verblijfsregeling en behelst het recht om het kind bij zich te hebben en het nemen van de dagdagelijkse opvoedingsbeslissingen. Dit staat als recht van materiële bewaring tegenover het veel ingrijpender recht van juridische bewaring. Dit persoonlijk contact kan slechts om zeer ernstige redenen geweigerd worden. ${ }^{209}$

\section{d) Bewind over de goederen van het kind en het genotsrecht op deze goederen}

Daar een minderjarige onbekwaam is, treden de ouders automatisch op als bewindvoerder. Dit geeft hen de bevoegdheid om de goederen van het kind te beheren en het kind te vertegenwoordigen. ${ }^{210}$ Bovendien krijgen de ouders ook een genotsrecht op de goederen, hetgeen neerkomt op een soort vruchtgebruik. ${ }^{211}$ Met de eventuele inkomsten die hieruit voorvloeien, dient in de eerste plaats aan de onderhoudsplicht te worden voldaan.

98.- Uiteraard dient elke beslissing van de ouder die een weerslag heeft op het leven van het kind, genomen te worden in het belang van het kind (zie infra 111). ${ }^{212}$

\section{UITOEFENING}

99.- In beginsel oefenen beide ouders het gezag gezamenlijk uit, zelfs wanneer zij niet (meer) samenleven. ${ }^{213}$ Dit wordt het gezagsco-ouderschap genoemd. ${ }^{214}$ Redelijkerwijze kan echter niet worden verwacht dat vader en moeder voor elke mogelijke opvoedingsbeslissing samen optreden. Dit zou in de praktijk niet werkzaam zijn. Vandaar dat de wetgever heeft voorzien in een wettelijk vermoeden van instemming van de andere ouder wanneer de ene alleen optreedt. $^{215}$ Let wel: voor de meeste beslissingen omtrent de juridische staat van het kind vereist de wet uitdrukkelijk een gezamenlijk optreden, het vermoeden van instemming is in die situaties niet toepasbaar. Voor de minder ingrijpende daden van bewaring mag elk van de ouders alleen optreden.

\footnotetext{
${ }^{208}$ Art. 374 § 1, lid 2 BW.

${ }^{209}$ Art. 374 § 1, lid 4 BW; zie Wuyts 2013, p. 331.

${ }^{210}$ Art. 376, lid 1 BW.

${ }^{211}$ Swennen 2014, p. 405.

${ }^{212}$ Verschelden 2007b, p. 69.

${ }^{213}$ Art. 374 § 1, lid 1 BW.

${ }^{214}$ Audoore 2012, p. 55.

${ }^{215}$ Art. 373, lid 2 BW.
} 
100.- Bereiken de ouders in een bepaalde kwestie geen eensgezindheid, dan kan de zaak bij de familierechtbank aanhangig worden gemaakt. ${ }^{216}$ De rechter kan dan besluiten om één van de ouders te machtigen om welbepaalde handelingen alleen te verrichten of kan zelf knopen doorhakken in het belang van het kind. De gezagsuitoefening exclusief toekennen aan een ouder is evenwel niet mogelijk. ${ }^{217}$

101.- Zoals vermeld, blijft de beschreven regeling in principe gelden bij niet-samenlevende ouders, hoewel het niet mag verbazen dat eventuele problemen het vaakst optreden in deze situatie. Belangrijk verschilpunt is echter dat exclusief gezagsrecht in dat geval wel kan worden toegekend: ${ }^{218}$

- als de ouders geen overeenstemming kunnen bereiken over de organisatie van de huisvesting van het kind of over belangrijke opvoedingsbeslissingen; of

- als deze overeenstemming in strijd is met het belang van het kind.

De rechter kan dus een ouder uitsluiten van het ouderlijk gezag, maar hij is hier niet toe verplicht. $^{219}$ Gelet op de concrete omstandigheden heeft hij een ruime beoordelingsmarge. Niets belet hem om het gezamenlijk gezag te behouden.

102.- Deze zuivere regimes van gezamenlijk of uitsluitend ouderlijk gezag (de uitersten van het spectrum) kunnen naar believen worden getemperd. Zo kan de rechter binnen een regime van uitsluitende gezagsuitoefening enkele beslissingen aanwijzen die toch met instemming van beide ouders moeten worden genomen en bij een stelsel van gezamenlijke uitoefening kan hij naar analogie met de regeling van artikel 373 BW één ouder machtigen om bepaalde handelingen alleen uit te voeren. ${ }^{220}$

De ouder die het gezag niet meer mag uitoefenen in het kader van een exclusieve toewijzing aan de andere ouder, verkrijgt wel het recht om toezicht te houden op diens opvoeding. Daarnaast behoudt hij zijn beslissingsrecht over de staat van de persoon en een recht op persoonlijk contact. $^{221}$

103.- Let wel: deze uitoefening van gezagsrechten mag echter niet worden verward met de verblijfsregeling voor het kind. Komen ouders hieromtrent niet tot een overeenstemming, dan moet de rechtbank op vraag van minstens één van hen bij voorrang de mogelijkheid onderzoeken om het verblijf van het kind op een gelijkmatige manier tussen hen vast te leggen. ${ }^{222}$ Dit zogenaamde 'verblijfsco-ouderschap' is daarmee sinds de wetswijziging van $2006^{223}$ het uitgangspunt geworden. Het hoeft niet te verbazen dat voordien vaders meestal

\footnotetext{
${ }^{216}$ Art. 373 BW.

${ }^{217}$ Art. 373, lid 3 en 4 BW; Swennen 2014, p. 407.

${ }^{218}$ Art. 374 § 1, lid 2 BW.

${ }^{219}$ Audoore 2012, p. 55.

${ }^{220}$ Antokolskaia \& Verschelden 2012, pp. 179-180.

${ }^{221}$ Art. 374, § 1, lid 4 BW.

${ }^{222}$ Art. 374, § 2, lid 2 BW.

${ }^{223}$ Wet 18 juli 2006 tot het bevoorrechten van een gelijkmatig verdeelde huisvesting van het kind van wie de ouders gescheiden zijn en tot regeling van de gedwongen tenuitvoerlegging inzake huisvesting van het kind, BS 4 september 2006.
} 
aan het kortste eind trokken. Rechters bleken haast systematisch het hoofdverblijf aan de moeder toe te kennen, zonder hiervoor steeds een concrete verantwoording te bieden. ${ }^{24}$

De initiatiefnemers van het wetsontwerp - in het bijzonder senator GUY SWENNEN - wilden zo de overduidelijke discriminatie van vaders bij het uitwerken van een dergelijke regeling te lijf gaan. ${ }^{225}$ Belangengroeperingen als $\mathrm{BGMK}^{226}$ en $\mathrm{MEP}^{227}$ hebben daarbij eveneens een cruciale rol gespeeld. ${ }^{228}$ Een principieel gelijkmatig verdeelde huisvesting zou de gelijkheid tussen ouders moeten bevorderen.

\section{TUSSENBESLUIT}

104.- Het ouderlijk gezag is - in tegenstelling tot de afstamming - geen vast gegeven, maar moduleerbaar naargelang de concrete omstandigheden. Leven de ouders niet meer samen dan is zelfs een gehele uitsluiting van gezagsrechten mogelijk in het belang van het kind. Vandaar de stelling die ik reeds in het vorige deel heb verdedigd, dat een toetsing aan het belang van het kind hier thuishoort en niet in het afstammingsrecht.

Waar mogelijk moet mijns inziens steeds de biologische afstammingsband worden gevestigd, ${ }^{229}$ eventueel met correcties op de gezagsrechten. ${ }^{230}$ Is een verregaandere inperking nodig dan biedt de mogelijkheid van de (gedeeltelijke) ontzetting uit het ouderlijk gezag een uitweg.

\section{DE ONTZETTING ALS REMEDIE?}

105.- De ontzetting uit het ouderlijk gezag is een maatregel gevorderd door de procureur des Konings en uitgesproken door de jeugdrechtbank tegen de onwaardige ouder: ${ }^{231}$ alle of bepaalde ouderlijke rechten worden de ouder ontnomen, waaronder het recht van 'bewaring' en opvoeding, het ouderlijk vruchtgenot, het recht om levensonderhoud te vorderen en erfaanspraken. ${ }^{232}$ Het gaat in elk geval om een tijdelijke sanctie. ${ }^{233}$ De afstammingsbanden blijven uiteraard intact.

106.- In theorie is de ontzetting daarom de ideale 'remedie' om de sociaal onwenselijke gevolgen van een (biologische) afstammingsband te kunnen uitschakelen. De lege lata is ze nochtans slechts mogelijk in zeer strikt omschreven gevallen en bedoeld als sanctie, met name wanneer het kwaad al is geschied ten aanzien van het kind. ${ }^{234}$ Met de lege ferenda zou hetzelfde effect kunnen worden bereikt door de rechter de mogelijkheid te geven om bepaalde

\footnotetext{
${ }^{224}$ Voor een zeer uitgebreide analyse zie Poelman \& Kruythooft 2010, pp. 20-40.

${ }^{225}$ Memorie van toelichting, Parl.St. Kamer, nr. 51-1673/001, 6.

${ }^{226}$ Belangenverdediging Gescheiden Mannen en hun Kinderen. Zie www.bgmk.org/.

${ }^{227}$ Mouvement pour l'égalité parentale. Zie www.egaliteparentale.be/.

${ }^{228}$ Martens 2007, pp. 1-17.

${ }^{229}$ Gerlo 2002, pp. 103-104.

${ }^{230}$ Brussel ( $3^{\mathrm{e}}$ k.) 9 november 2009, RTDF 2010, 656; Luik 7 juni 2010, 2009/RG/668 en 2009/RG/1216, onuitg; Rb. Brussel (12 ${ }^{\mathrm{e}}$ k.) 23 januari 2008, JLMB 2008, 1067; Rb. Luik ( $3^{\mathrm{e}}$ k.) 21 december 2007, RTDF 2009, 196, m.nt. van G. Mathieu.

${ }^{231}$ Art. 32, lid 3 JBW.

${ }^{232}$ Art. 33 JBW.

${ }^{233}$ Art. $60 \mathrm{JBW}$.

${ }^{234}$ Art. 32, lid 1 JBW.
} 
ouderlijke rechten meteen bij de vestiging van de afstammingsband te 'amputeren'. Het kind behoudt dan de mogelijkheid om door de betreffende ouder te worden opgevoed, ${ }^{235}$ evenals een erfrecht. ${ }^{236}$

\section{OUDERLIJK GEZAG VOOR IEDEREEN?}

107.- Wordt aanvaard dat ouderlijke rechten en afstamming niet noodzakelijk moeten samengaan, dan kan de vraag worden gesteld of die rechten kunnen worden toegekend aan iemand anders. Het ouderlijk gezag zou kunnen worden toegekend aan een sociale ouder die deze rechten en plichten de facto al uitoefent, en bij uitbreiding eventueel aan meerdere personen tegelijk.

108.- Het Nederlandse systeem voorziet in een dergelijke loskoppeling van afstamming en ouderlijk gezag, weliswaar voor nog steeds maximaal 2 personen. ${ }^{237}$ In Nederland kan de partner van een ouder evenwaardig gezagsdrager worden, ${ }^{238}$ zonder dat deze echtgenoot of geregistreerde partner hoeft te zijn, terwijl in België dit enkel mogelijk is via adoptie. ${ }^{239}$ Artikel 1:253t Nederlandse BW vereist daartoe dat de verzoekende ouder uitsluitend het ouderlijk gezag uitoefent en dat de niet-ouder (man of vrouw) in een nauwe persoonlijke betrekking tot het kind staat. Als het kind een andere juridische ouder heeft, gelden extra voorwaarden. De gelijkwaardigheid van de partners in Nederland betekent tevens dat bij beëindiging van de relatie geen voorkeur wordt gegeven aan de ouders ten nadele van de nietouder en dat enkel de rechter het ouderlijk gezag kan stopzetten. ${ }^{240}$

Het Nederlandse model heeft de verdienste dat het tracht de feitelijke stand van zaken te regelen in functie van het welzijn van het kind en er rekening mee houdt dat het belang van het kind met de tijd kan veranderen. Doordat ouderlijk gezag te allen tijde aan de rechterlijke toets kan worden voorgelegd, is het welzijn van het kind voldoende gewaarborgd.

109.- Naar Engels recht zou eventueel ouderlijk gezag aan meer dan twee personen kunnen worden toegekend door de rechter. ${ }^{241}$ Mits op een duidelijke manier ingeschreven in de wet en gekoppeld aan een aantal voorwaarden hoeft een dergelijke regeling niet tot meer conflicten te leiden, of een uitholling van het gezagsrecht te betekenen. Het is bovendien niet omdat in België de mogelijkheid om naar de rechtbank te stappen als derde ouder beperkter is, dat deze conflicten er niet zijn.

110.- Door het stringenter maken van de regels kan de rechter bij conflict beter ingrijpen in het belang van het kind en kan hij het oudere kind horen en laten meedenken. Het gezag van de ouder zou dan een beslissingsrecht op maat ${ }^{242}$ kunnen worden, waar ook nog rekening kan

\footnotetext{
${ }^{235}$ Art 7 IVRK.

${ }^{236}$ Swennen 2011 c, p. 60

${ }^{237}$ Art. 1:252, lid 2, e); Art. 1:253t lid 1 Nederlandse BW; Antokolskaia, Schrama, Boele-Woelki e.a. 2014, p. 47.

${ }^{238}$ Boele-Woelki \& Swennen 2012, p. 273

${ }^{239}$ Art. 344-1 BW

${ }^{240}$ Antokolskaia, Schrama, Boele-Woelki e.a. 2014, p. 61.

${ }^{241}$ Section 2 Children Act 1989, specifiek leden 5-7.

${ }^{242}$ Wuyts 2012a, p. 14.
} 
gehouden worden met een aantal opties, zoals het toekennen van volledig ouderschap in geval van overlijden van de juridische ouder. Uitgangspunt dient echter te blijven dat ouderschapsrechten- en plichten voor andere personen dan de juridische ouder(s) beperkt dienen te blijven tot de dagelijkse beslissingen. ${ }^{243}$

${ }^{243}$ Swennen 2014, p. 325. 


\section{- DEEL III. - \\ HET VADERSCHAP OPGESPLITST?}

\section{ALGEMEEN}

111.- In België worden rechten en plichten van juridische vaders reeds over verschillende personen verdeeld. Het vaderschap wordt 'opgesplitst' via de toekenning van omgangsrechten en alimentatieverplichtingen. Kan deze denkpiste worden verder gezet?

In wat volgt bespreek ik een aantal bijzondere situaties, opgedeeld in twee categorieën, met name de 'betaalvader' en de 'bezoekvader'. In beide delen wordt eerst teruggegrepen naar de algemene rechten en plichten die samenhangen met een afstammingsband om vervolgens te kijken naar de oplossingen die het recht biedt in de gevallen waarin daarvan geen sprake is. In een laatste deel wordt de mogelijkheid geopperd om ook aan het louter biologisch verwantschap bepaalde gevolgen te koppelen.

\section{DE 'BETAALVADER'}

\section{DE OUDERLIJKE ONDERHOUDSPLICHT}

112.- Krachtens artikel 203 BW hebben ouders een eenzijdige onderhoudsverplichting tegenover hun minderjarige en hun studerende meerderjarige kinderen. Ze moeten naar evenredigheid van hun middelen instaan voor huisvesting, levensonderhoud, gezondheid, toezicht, opvoeding, opleiding en ontplooiing van hun kinderen.

Deze verplichting wordt in eerste instantie in natura uitgevoerd in de ouderlijke woning. ${ }^{244}$ Wonen de ouders niet (meer) samen, dan zal de plicht worden voldaan in de vorm van een geldelijke bijdrage, die wordt begroot aan de hand van de parameters van artikel 1321 Gerechtelijk Wetboek. ${ }^{245}$ De kinderen kunnen aanspraak maken op de gemiddelde levensstandaard ${ }^{246}$ van de ouders, en dit tot aan de voltooiing van hun opleiding, ${ }^{247}$ zelfs wanneer die doorloopt tot na de meerderjarigheid.

113.- Deze specifieke ouderlijke plicht doet uiteraard geen afbreuk aan de algemene onderhoudsplicht die op grond van artikel 205 BW bestaat tussen verwanten in de rechte lijn. ${ }^{248}$ Deze verplichting is wederkerig, zodat ook een ouder die behoeftig is recht heeft op levensonderhoud van zijn kinderen. ${ }^{249}$

\footnotetext{
${ }^{244}$ Brussel 14 september 2006, JT 2007, 190; zie Swennen 2014, p. 428.

${ }^{245}$ O.a. de middelen van de ouders, de gewone en buitengewone kosten en de verblijfsregeling moeten hierbij in acht worden genomen, zie Brouwers 2013, p. 23.

246 Brouwers 2013, p. 22.

247 De studies moeten een normale voortgang kennen. Een verlenging voor een verdere specialisatie is mogelijk, zie ook Antokolskaia \& Verschelden 2012, pp. 163-216.

${ }^{248}$ Antokolskaia \& Verschelden 2012, p. 215.

249 Art. 207 BW.
} 


\section{DE VORDERING TOT LEVENSONDERHOUD TEGEN DE VERMOEDELIJKE VERWEKKER}

114.- Zelfs indien er geen afstammingsband tussen de biologische vader en het kind werd vastgesteld, dan nog beschikt het kind steeds over een onderhoudsvordering. Tijdens zijn minderjarigheid zal het aan de moeder zijn om, in hoedanigheid van wettelijk vertegenwoordiger, de vordering in te stellen in naam en voor rekening van het kind. ${ }^{250}$

115.- Het is niet vereist dat de biologische band met zekerheid is vastgesteld. De vordering steunt op een vermoedelijke genetische band, ${ }^{251,252}$ waarvan het bestaan kan worden aangetoond door het bewijs van geslachtsgemeenschap gedurende het wettelijke tijdvak van de verwekking. ${ }^{253}$ Het is dan aan de verweerder om te bewijzen dat hij niet de verwekker is van het kind. ${ }^{254}$

Zowel de eiser als de verweerder kunnen hiertoe een DNA-onderzoek vorderen. De rechter kan dit evenwel niet ambtshalve bevelen, daar artikel 331octies BW enkel van toepassing is in afstammingsgedingen. ${ }^{255}$

116.- De vordering tot uitkering voor levensonderhoud tegen de vermoedelijke verwekker is in geen geval een afstammingsvordering. ${ }^{256,257} \mathrm{Ze}$ kan worden aangewend in situaties waarin het onwenselijk of onmogelijk ${ }^{258}$ is om een afstammingsband te vestigen. ${ }^{259}$

Deze onderhoudsvordering mag enkel worden ingesteld op voorwaarde dat het juridische vaderschap van het kind niet is vastgesteld of succesvol betwist werd (door iemand anders dan de biologische vader $\left.{ }^{260}\right) .{ }^{261}$ Bij wijze van reactie kan de verwekker op zijn beurt evenwel een vordering tot vestiging van de afstamming instellen. ${ }^{262}$

\footnotetext{
${ }^{250}$ Art. 337 en art. 376, lid 3 BW.

${ }^{251}$ De spermadonor in het kader van de MBV-wet buiten beschouwing gelaten. Zie Swennen 2014, p. 440.

${ }^{252}$ GwH 12 mei 2004, nr. 79/2004, JLMB 2004, 1660, m.nt. van N. Banneux; NJW 2004, 1202, m.nt. van G. Verschelden; TJK 2005, 94, m.nt. van S. Brouwers.

${ }^{253}$ Art. 336, lid 1 BW.

${ }^{254}$ Art. 338bis BW. Zie ook Swennen 2010, p. 33.

${ }^{255}$ Brouwers 2009, p. 266.

${ }^{256}$ Cass. 17 mei 1984, JT 1984, 599, m.nt. van J. Tulkens.

${ }^{257}$ Zie nochtans GwH 12 mei 2004, nr.79/2004, JLMB 2004, afl. 38, 1660, m.nt. van N. Banneux; NJW 2004, afl. 88, 1202, m.nt. van G. Verschelden; $R W$ 2004-05, afl. 7, 256; RTDF 2004, afl. 3, 651; TJK 2005, afl. 2, 94, m.nt. van S. Brouwers, waar het Hof voor wat betreft de verjaring de vordering tot uitkering voor levensonderhoud wel vergelijkbaar acht met een afstammingsvordering. Immers, beide vorderingen "steunen op een afstamming die in het ene geval vaststaat en in het andere geval verondersteld wordt." (r.o. B.3)

${ }^{258}$ Het vestigen van het vaderschap is onmogelijk indien verboden na belangenafweging, m.n. bij verkrachting van de moeder of het bestaan van een absoluut huwelijksbeletsel. Zie Swennen 2014, p. 436.

${ }^{259}$ Swennen 2010, p. 32.

${ }^{260}$ Zijn eigen vaderschap moet immers kunnen worden gevestigd opdat de betwisting succesvol kan zijn (art. 318, § 5 BW).

${ }^{261}$ Brouwers 2009, p. 267.

${ }^{262}$ Swennen 2010, p. 32.
} 
Omgekeerd is het voor de verwekker niet mogelijk om een vordering tot vaststelling van het vaderschap te doen herleiden tot een onderhoudsplicht. Indien er toch al een juridische vader is, verhindert bovendien niets de verwekker om op vrijwillige basis een bijdrage te leveren. ${ }^{263}$

117.- Omdat er geen afstammingsband wordt gevestigd zijn de mogelijke gevolgen beperkt tot een verplichting in geld (levensonderhoud, opvoeding en passende opleiding) ${ }^{264}$ en het ontstaan van huwelijksbeletselen. ${ }^{265}$ De verwekker verwerft geen verdere ouderschapsrechtenof plichten. ${ }^{266}$

118.- Opnieuw kan worden aangehaald dat de vestiging van de afstamming in de meeste gevallen wellicht een beter alternatief vormt. Een (gedeeltelijke) ontzetting uit het ouderlijk gezag kan, indien nodig, de (sociaal) onwenselijke gevolgen ervan (voorlopig) uitschakelen. ${ }^{267}$ Behalve een recht op levensonderhoud bekomt het kind dan eveneens een erfrecht, zonder dat dit wederkerig hoeft te zijn.

\section{DE ONEIGENLIJKE ONDERHOUDSPLICHT VAN DE STIEFVADER}

119.- In het thema van opsplitsing van het vaderschap kan er op gewezen worden dat in het huidige Belgische recht ook op de stiefouder een deel van de verantwoordelijkheid rust. Het kind beschikt namelijk over een aantal aanspraken ten aanzien van de nieuwe partner van een ouder. Zo is de stiefouder die gehuwd is met de ouder verplicht tot een bijdrage in de lasten van het huwelijk, ${ }^{268}$ waaronder ook de opvoedingskosten van de kinderen die deel uitmaken van het gezin, ook al gaat het om niet-eigen kinderen. Iedere schuld die door een der echtgenoten ten behoeve van de huishouding en de opvoeding van de kinderen wordt aangegaan, verbindt de andere echtgenoot bovendien hoofdelijk. ${ }^{269}$ Tot slot dient de langstlevende stiefouder "binnen de grenzen van hetgeen hij heeft verkregen uit de nalatenschap van de vooroverledene en van de voordelen die deze hem mocht hebben verleend bij huwelijkscontract, door schenking of bij testament ${ }^{270}$ in te staan voor huisvesting, levensonderhoud, toezicht, opvoeding en opleiding van de kinderen van de vooroverleden echtgenoot.

120.- De wettelijk samenwonende partner heeft analoge verplichtingen. ${ }^{271}$ Hij hoeft evenwel niet noodzakelijk de 'stiefouder' te zijn. Ook ingeval van een andersoortige relatie blijft de verplichting overeind. ${ }^{272}$

\footnotetext{
${ }^{263}$ De natuurlijke verbintenis tot levensonderhoud wordt omgezet in een burgerlijke verbintenis door de vrijwillige uitvoering ervan of de belofte om zulks te doen. Cass. 6 juni 1975, Arr.Cass. 1975, 1066, m.nt. van T.A.; RCJB 1976, 283, m.nt. van F. Rigaux. Zie ook Adams 2008, p. 56.

${ }^{264}$ Artt. 336 en 339 BW.

265 Art. 341 BW.

${ }^{266}$ Swennen 2014, p. 437.

267 Swennen 2014, p. 438.

${ }^{268}$ Art. $221 \mathrm{BW}$.

${ }^{269}$ Art. 222 BW.

${ }^{270}$ Art. 203, $\S \S 1$ en 2 BW; Barbaix 2009, pp. 37-43.

${ }^{271}$ Art. 1477, §§ 3-5 BW; Barbaix 2009, pp. 37-47.

272 Swennen 2014, p. 436.
} 
121.- In elk geval gaat het slechts om een geldelijke bijdrage. Bij gebrek aan ouderlijk gezag is er immers geen sprake van een morele en intellectuele opvoedingsplicht. ${ }^{273}$ Evenmin bestaat er een erfrecht voor het kind, tenzij voorzien bij testament. ${ }^{274}$

\section{DE 'BEZOEKVADER'}

\section{HET RECHT OP PERSOONLIJK CONTACT}

122.- Ouders zijn principieel gerechtigd om contact te onderhouden met hun minderjarige kinderen (vgl. infra nr. 127 e.v.). De grondslag daarvoor is terug te vinden in het bewaringsrecht, dat de gezagsdragende ouders toelaat om het kind bij zich te houden. ${ }^{275}$

123.- Als de ouders gescheiden leven, wordt dit recht gemoduleerd in een verblijfsregeling. Bij gebrek aan akkoord verdient een verblijfsco-ouderschap bij voorrang onderzocht te worden door de rechter (zie supra nr. 103) ${ }^{276}$

124.- Ook de ouder die geen gezag (meer) uitoefent, behoudt een principieel recht op persoonlijk contact, dat slechts om zeer ernstige redenen mag worden geweigerd. ${ }^{277}$ Het gaat dan niet langer om een 'verblijfsregeling', maar om een 'omgangsregeling'. De (louter) biologische vader bevindt zich in een vergelijkbare situatie.

\section{HET OMGANGSRECHT VAN DE BIOLOGISCHE VADER 2.1 De bijzondere affectieve band}

125.- Principieel zijn het de ouders die, op grond van het ouderlijk gezag, bepalen met wie het kind omgaat. Van deze regel heeft de wetgever in twee gevallen afgeweken: ten eerste ten voordele van de grootouders - die net als de ouders principieel contactgerechtigd zijn - en ten tweede voor ieder ander persoon die met het kind een bijzondere affectieve band heeft. ${ }^{278}$ Deze laatste categorie wordt virtueel contactgerechtigd genoemd. Wil de verwekker een recht op persoonlijk contact verkrijgen, dan moet hij onder deze laatste categorie vallen.

126.- De bijzondere affectieve band moet aangetoond worden. De verzoeker moet een zeker verleden met het kind kunnen aangeven, een band waarbij het in het belang van het kind is dat hij wordt voortgezet. Eens het bestaan van die band vaststaat, kan de uitoefening van het omgangsrecht enkel nog worden geweigerd indien dit strijdig is met het belang van het kind. Deze strijdigheid moet worden bewezen door de juridische ouders. ${ }^{279}$

\footnotetext{
${ }^{273}$ Senaeve $1989 / 90$, pp. $475-503$.

${ }^{274}$ Voor de successierechten geldt daarbij het tarief in rechte lijn: zie art. 50 Vl.W.Succ. en GwH nr. 163/2012, 20 december 2012, BS 19 februari 2013, 9567; Fiscoloog 2013, afl. 1323; RW 2012-13 (samenvatting), afl. 23, 919.

${ }^{275}$ Swennen 2013, pp. 257-264.

${ }^{276}$ Art. 374 §2, lid 2 BW; Martens 2007, pp. 1-16.

277 Art. 374 §1, lid 4 BW.

${ }^{278}$ Art. 375bis BW.

${ }^{279}$ Brussel (jk.) (19e k.) 18 februari 2005, EJ 2005, afl. 3, 43, m.nt. van A. De Wolf.
} 
127.- Wat een "bijzondere affectieve band" juist inhoudt, wordt vrij ingevuld door de rechter. ${ }^{280}$

Uit de huidige rechtspraak van het Hof van Cassatie ${ }^{281} \mathrm{kan}$ alleszins worden afgeleid dat die band niet actueel noch wederkerig ${ }^{282}$ hoeft te zijn. De eenzijdige band die de verzoeker heeft met het kind kan volstaan, zolang de uitoefening van het omgangsrecht in het belang van het kind is. ${ }^{283}$ Dat de band niet wederkerig hoeft te zijn, kan van belang zijn bij zeer jonge kinderen. Dat er ook geen actualiteitsvereiste geldt, betekent dat jarenlange vervreemding evenmin een hinderpaal vormt, weliswaar in zoverre dit niet aan de biologische vader toerekenbaar is. ${ }^{284}$

128.- Artikel 375 bis BW is principieel gericht op het behoud van reeds gevestigde relaties met het kind. ${ }^{285}$ Nochtans kunnen ook potentiële banden beschermenswaardig zijn. Voor de situatie waarin de biologische vader verhinderd werd een dergelijke band op te bouwen, biedt de rechtspraak van het EHRM een oplossing.

\subsection{De rechtspraak van het EHRM}

129.- Het EHRM plaatst dit vraagstuk onder het toepassingsgebied van artikel 8 EVRM. De begrippen family life en private life dekken immers een ruimere lading dan de relaties tussen ouders en kinderen in een juridische betekenis: er is ruimte voor de sociale en biologische werkelijkheid. $^{286}$

130.- Opdat de relatie tussen biologische vader en kind de kwalificatie van family life zou verkrijgen, moeten er behalve de biologische band echter ook andere wettelijke of feitelijke elementen kunnen worden aangetoond. ${ }^{287}$ In uitzonderlijke gevallen kan ook intended family life onder het toepassingsgebied van artikel 8 EVRM worden geplaatst, namelijk wanneer het gebrek aan een bestaand family life niet toerekenbaar is aan de verzoeker. ${ }^{288}$

Volgens het EHRM zijn een biologische vader en zijn kind namelijk onherroepelijk met elkaar verbonden door een natuurlijke band. De effectieve relatie tussen beiden kan, door redenen van praktische en juridische aard, echter geheel worden gecontroleerd door de moeder en in voorkomend geval, haar echtgenoot. ${ }^{289}$

\footnotetext{
${ }^{280}$ Brussel (jk.) 22 juni 2011, RTDF 2012, afl. 2, 413; De Maeyer \& Vergauwen 2009, p. 863.

${ }^{281}$ Cass. 16 januari 2009, RABG 2009, 858, m.nt. van E. De Maeyer en C. Vergauwen; RTDF 2009, 505, T. Fam. 2009, 961, m.nt. van R. Vasseur.

${ }^{282}$ Zie Gent (15e k.) nr. 2004/JR/80, 7 februari 2005, NJW 2006, afl. 134, 36, m.nt. van G. Verschelden; TBBR 2007, afl. 4, 256, waar het wederkerigheidsvereiste wel werd gesteld voor een kind van twee jaar oud.

${ }^{283}$ Wuyts 2013, p. 526.

${ }^{284}$ Swennen 2014, p. 417

${ }^{285}$ Verslag namens de Commissie voor de Justitie, Parl.St.Kamer 1993-94, nrs. 48-1430/4, 9.

${ }^{286}$ Vonk 2013, pp. 515-520.

${ }^{287}$ EHRM 1 juni 2004, 45582/99 (Lebbink/Nederland), § 37.

${ }^{288}$ EHRM 21 december 2010, 20578/07 (Anayo/Duitsland), § 57; EHRM 22 juni 2004, 78028/01 en 78030/01 (Pini and Others/Romania), §§ 143 en 146; EHRM 22 juni 2004, 78028/01 en 78030/01 (Nylund/Finland).

${ }^{289}$ EHRM 21 december 2010, 20578/07 (Anayo/Duitsland), § 60.
} 
In dat opzicht is dus ook een louter potentiële relatie tussen een biologische vader en zijn kind te beschouwen als family life. Hiertoe is wel het bestaan van close personal ties vereist, hetgeen vervat kan liggen in factoren als de aard van de relatie tussen de natuurlijke ouders evenals aantoonbare interesse en engagement van de vader voor het kind. ${ }^{290} \mathrm{Bij}$ de beoordeling wordt rekening gehouden met zowel de periode voor de geboorte, als die erna. ${ }^{291}$

131.- Zelfs wanneer een vorm van family life niet kan worden vastgesteld, zo stelt het Hof, raakt de relatie tussen een biologische vader en zijn kind hoe dan ook steeds het private life van de betrokkenen, ${ }^{292}$ meer bepaald: het recht om te weten van wie men afstamt en dit weten ook op een bepaalde manier erkend te zien. ${ }^{293}$

132.- Kortom, wordt een recht van omgang als een kwestie van (intented) family life beschouwd, dan zijn er naast de biologische band bijkomende elementen vereist die dit rechtvaardigen. Betreft dit omgangsrecht daarentegen een onderdeel van het privéleven, dan zou de loutere biologische band eventueel al kunnen volstaan om de bescherming van artikel 8 EVRM uit te lokken. ${ }^{294}$

133.- Let wel: het feit dat een bepaalde situatie onder het toepassingsgebied van artikel 8 EVRM ressorteert, betekent niet noodzakelijk dat er sprake is van een schending. Mits bij wet voorzien en noodzakelijk in een democratische samenleving kan een inmenging in dit gezinsof privéleven immers gerechtvaardigd zijn. ${ }^{295}$

134.- Dit alles kan worden verduidelijkt aan de hand van twee toonaangevende arresten van het EHRM, Anayo t./ Duitsland ${ }^{296}$ en Schneider t./ Duitsland ${ }^{297}$.

In beide zaken was de eiser de (vermoedelijke) biologische vader van de kinderen van een gehuwde vrouw, wier echtgenoot krachtens een vaderschapsvermoeden als juridische vader was aangewezen. Aangezien dit vaderschap naar Duits recht niet kon worden betwist, vorderden zowel Anayo als Schneider slechts een recht op persoonlijk contact en een recht op informatie over het kind.

Om hiervoor in aanmerking te komen, vereist de Duitse wet uitdrukkelijk het bestaan van een 'sozial-familiäre Beziehung'. ${ }^{298}$ In casu hadden de respectieve moeders en hun echtgenoten de eisers echter steeds verhinderd contact te zoeken met hun kinderen, ${ }^{299}$ waardoor de vereiste socio-affectieve band onmogelijk kon worden opgebouwd. In beide gevallen werd het verzoek dan ook zonder meer geweigerd door de Duitse rechter.

\footnotetext{
${ }^{290}$ EHRM 18 mei 2006, 55339/00 (Rozanski/Polen), § 64.

${ }^{291}$ EHRM 21 december 2010, 20578/07 (Anayo/Duitsland), § 57.

${ }^{292}$ EHRM 21 december 2010, 20578/07 (Anayo/Duitsland), § 58.

${ }^{293}$ EHRM 6 juli 2010, 36498/05 (Backlund/Finland), § 37.

${ }^{294}$ Vonk 2013, pp. 515-521. In diezelfde zin: Swennen 2013c, pp. 284-285.

${ }^{295}$ Art. 8, lid 2 EVRM.

${ }^{296}$ EHRM 21 december 2010, 20578/07 (Anayo/Duitsland).

${ }^{297}$ EHRM 15 september 2011, 17080/07 (Schneider/Duitsland).

${ }^{298} \S 1685$ (2) BGB.

299 Waartoe zij het recht hadden op grond van $§ 1632$ (2) BGB.
} 
135.- In zijn beoordeling erkent het Hof dat een loutere biologische band niet volstaat om onder de toepassing van artikel 8 EVRM te vallen (Anayo, §56 / Schneider, § 80). Het voegt daar wel meteen aan toe dat wanneer het ontbreken van de benodigde feitelijke aanknopingspunten niet toerekenbaar is aan de biologische vader, zijn intended family life alsnog beschermd wordt onder het verdrag (Anayo, §57 / Schneider, § 81). Vervolgens wordt gepreciseerd dat de relatie van een man met zijn kind een belangrijke weerslag heeft op zijn persoonlijke identiteit en hoe dan ook raakt aan zijn privéleven, zelfs los van het al dan niet bestaan van een gezinsleven (Anayo, §58 / Schneider, § 82). In beide zaken concludeert het Hof aldus dat de weigering van het omgangsrecht wel degelijk een inmenging betekent op het recht op eerbiediging van het privéleven.

136.- Zoals hierboven reeds aangehaald, rest dan nog de vraag of deze inmenging gerechtvaardigd is, dan wel een schending uitmaakt van artikel 8 EVRM.

Allereerst schrijft het Hof voor dat in alle zaken waarin de rechten van ouders en kinderen in het geding zijn, het belang van het kind resoluut voorrang verdient. Afhankelijk van de aard en de ernst van de zaak kan het belang van het kind ook dat van de ouders overtreffen (Anayo, $\S 65$ / Schneider, $\S 93) .{ }^{300}$

Door zonder meer de voorkeur te geven aan de bescherming van het gezinsleven van de juridische ouders en hun huwelijkse kinderen, zonder in concreto na te gaan of contacten tussen een kind en de biologische vader het belang van het kind zou kunnen dienen, miskennen de Duitse rechtbanken het recht op eerbiediging van het privéleven van de verzoeker (Anayo, §§71-73). De zoektocht naar een billijk evenwicht vereist immers een onderzoek naar de specifieke omstandigheden van de zaak (Schneider, § 100).

Bovendien hebben de nationale rechters geen rekening willen houden met het feit dat de biologische vaders om redenen buiten hun wil om niet in staat waren om een relatie op te bouwen met de kinderen (Schneider, § 98).

137.- Het Hof besluit dan ook zowel in de zaak Anayo (§73) als in de zaak Schneider ( $§ 105)$ tot een schending van artikel 8 EVRM.

138.- Uit de rechtspraak van het EHRM worden volgende vuistregels gedistilleerd bij een verzoek om omgang en informatie vanwege de (vermeende) biologische vader:

- De afwezigheid van een bestaande nauwe persoonlijke band met het kind mag er niet toe leiden dat de vordering automatisch wordt afgewezen;

- Bij afwezigheid van een dergelijke relatie dient worden nagegaan of de eiser in de juridische en/of feitelijke onmogelijkheid verkeerde om ze tot stand te brengen;

\footnotetext{
300 Zie ook EHRM 5 november 2002, 33711/96 (Yousef/Nederland), § 73 en EHRM 26 februari 2004, 74969/01 (Görgülü/Duitsland).
} 
- Is dit het geval, dan mag de vordering niet in abstracto worden geweigerd ter bescherming van het bestaande gezinsleven tussen de moeder het kind en de juridische vader; en

- Er zal in concreto moeten worden onderzocht of een relatie met de biologische vader in het belang van het kind is.

139.- Dit alles impliceert dat vanaf heden ook de verwekker de kans krijgt om, naast de juridische vader, een rol te spelen in het leven van het kind. ${ }^{301}$

\subsection{Tussenbesluit}

140.- Noch voor de Belgische rechter, noch voor het EHRM is de loutere aanwezigheid van een biologische band voldoende om een recht op persoonlijk contact te vestigen. ${ }^{302}$ Het Hof vereist hiertoe bepaalde bijkomende feitelijke of juridische elementen, hetgeen vergelijkbaar is met de bijzondere affectieve band die in België doorslaggevend is.

De uitspraken van het EHRM bieden evenwel een cruciale toevoeging aan de huidige criteria van artikel 375bis BW. Met name in de situatie waarin de biologische vader werd verhinderd om de bedoelde bijzondere affectieve band op te bouwen, wordt toch aanvaard dat zijn potentiële band kan volstaan.

141.- Gelet op het voorgaande, kan mijns inziens de bereidheid van de biologische vader om tijdig gerechtelijke stappen te ondernemen om een omgangsrecht af te dwingen op zich al voldoende zijn om zijn engagement jegens het kind te bewijzen. Is hij bovendien niet verantwoordelijk voor het ontbreken van een verdere bijzondere affectieve band, dan kan het omgangsrecht mijns inziens quasi automatisch worden toegekend. Een toets aan het belang van het kind biedt immers een voldoende waarborg opdat de problematische uitoefening van dit recht niet zal worden toegestaan.

\section{HET OMGANGSRECHT VAN DE SOCIALE VADER}

142.- Ook de gewezen stiefvader kan zich op artikel 375bis BW beroepen om een recht op contact en informatie te verkrijgen, indien hij een bijzondere affectieve band met het kind kan aantonen. ${ }^{303}$ Deze band mag evenwel niet louter steunen op het verleden met de ouder van het kind. Hetzelfde geldt mijns inziens voor de gewezen juridische vader.

\section{HET ATTEST VERWEKKERSCHAP?}

\section{BELGIË: DE LEGE LATA EN DE LEGE FERENDA}

143.- In België is het momenteel niet mogelijk om een vordering tot vaststelling van het loutere biologische vaderschap in te stellen. Een juridische erkenning van biologisch

\footnotetext{
${ }^{301}$ Wuyts 2013, p. 527.

302 Swennen 2013 c, p. 282.

${ }^{303}$ Cass. 16 januari 2009, RABG 2009, 858, m.nt. van E. De Maeyer en C. Vergauwen; RTDF 2009, 505; T. Fam. 2009, 961, m.nt. van R. Vasseur.
} 
vaderschap betekent steeds een wijziging in de juridische staat van 'vader' en kind. Samen met F. SWENNEN ${ }^{304}$ ben ik echter van mening dat de lege ferenda de verwekker over een vordering moet beschikken om dit biologische verwekkerschap te verifiëren en in voorkomend geval erkend te zien. ${ }^{305}$ Ik noem dit het 'attest van verwekkerschap'.

144.- Via een document dat het genetisch verwantschap bewijst, zouden biologische vader en kind dan aanspraak kunnen maken op een aantal afstammingsrechtelijke voordelen. Zo zou het 'attest van verwekkerschap' bijvoorbeeld:

- een voordeliger tarief in successierechten kunnen verantwoorden; en

- een basis kunnen vormen voor een recht op persoonlijk contact en informatie.

145.- Het compromis dat in dit voorstel vervat ligt, zou met andere woorden een soort van troostprijs betekenen voor de vader die geen volwaardige afstammingsband heeft kunnen of om het kind niet de voordelen van de bestaande afstammingsband te ontnemen - heeft willen vestigen. Daarnaast kan het een sluitend bewijsstuk uitmaken voor de vordering tot levensonderhoud tegen de verwekker.

146.- Ook zonder afstammingsprocedures moet het vaststellen van de biologische band echter mogelijk zijn. Zo is de situatie denkbaar waarin de verwekker de gezinscel van een kind niet wil opbreken en genoegen neemt met een bijrol. ${ }^{306}$ Is er geen juridische vader en grijpt de verwekker deze wettelijke optie aan om een juridische afstammingsband te vermijden, dan beschikken moeder en kind nog steeds over de mogelijkheid om een vordering tot levensonderhoud of een vordering tot gerechtelijke vaststelling van het vaderschap in te stellen. ${ }^{307}$

\section{RECHTSPRAAK VAN HET EHRM}

147.- In de arresten-Anayo en Schneider oordeelde het Hof dat de vaststelling van de natuurlijke band tussen verwekker en kind een belangrijk aspect uitmaakt van het privéleven van de verwekker (Anayo, §58 / Schneider, §82). ${ }^{308}$ Die vaststelling zou bijgevolg niet afhankelijk mogen worden gemaakt van de juridische vestiging van het vaderschap. ${ }^{309}$

148.- Nochtans stelde het Hof in de zaak-Kautzor dat de Staat over een ruime beoordelingsmarge beschikt om te bepalen of een beweerde biologische vader de mogelijkheid moet krijgen om te verifiëren of het kind van hem afstamt en in voorkomend geval dit biologisch vaderschap erkend te zien, zonder evenwel de juridische status van het kind te wijzigen $(\$ 79)$. Deze marge geldt zowel indien er al een juridische vader is, als wanneer het om een afzonderlijke vordering tot vaststelling van louter biologisch vaderschap zou gaan. $^{310}$

\footnotetext{
${ }^{304}$ Swennen 2013c, nr. 354.

${ }^{305}$ Zie ook voor Nederland: Vonk 2013, p. 515 en pp. 516-517.

${ }^{306}$ Swennen 2013c, nr. 354.

${ }^{307}$ Swennen 2013c, nr. 352.

${ }^{308}$ EHRM 22 maart 2012, 45071/09 (Ahrens/Duitsland), § 71 en EHRM 22 maart 2012, 23338/09 (Kautzor/Duitsland) § 73.

${ }^{309}$ Swennen 2013c, p. 284, nr. 354.

${ }^{310}$ Wuyts 2013, p. 521, nrs. 522, 707 en 709.
} 


\section{TUSSENBESLUIT}

149.- Het huidig Belgisch recht voorziet niet in de mogelijkheid om een vordering tot vaststelling van het loutere biologische vaderschap in te stellen. Gelet op de rechtspraak van het EHRM blijft België met (een gebrek) aan een dergelijke regeling binnen zijn beoordelingsmarge. ${ }^{311}$ De lege ferenda pleit ik echter voor de invoering van een 'attest van verwekkerschap'.

${ }^{311}$ Wuyts 2013, p. 521, nrs. 522, 707 en 709. 


\section{- BESLUIT -}

150.- Doelstelling van dit artikel was het concept vaderschap te onderzoeken in zijn juridische, biologische en sociale geleding, zowel op Belgisch als op Europees niveau. Het uitgangspunt is dat de functies en maatschappelijke ideeën over het vaderschap zo goed mogelijk in de wet dienen te worden weerspiegeld en idealiter samenvallen in één persoon. Wanneer dit niet zo is, moeten er keuzes worden gemaakt. Het Grondwettelijk Hof en de wetgever hebben daar verschillende ideeën over. De wetgever heeft een delicate evenwichtsoefening gemaakt in 2006, maar werd teruggefloten door het Hof dat zich daarvoor, niet altijd consequent, baseert op principes uit de Europese rechtspraak. Het Hof is (overwegend) tegen absolute regels en pleit voor een afstammingsrecht op maat van het kind. Ik heb de tegenovergestelde visie verdedigd. Afstamming moet duidelijk en eenvormig bij wet worden geregeld. Belangenafwegingen in elke zaak leiden tot een gebrek aan rechtszekerheid en in het ergste geval zelfs tot willekeur.

Uitgangspunt voor de afstamming dient het biologisch vaderschap te zijn. Is er een 'vacature' voor het vaderschap, dan wordt bij voorkeur de biologische waarheid juridisch vastgelegd. De gevolgen van een eventuele onwenselijke afstammingsband kunnen op andere manieren worden gecorrigeerd. Is er reeds een juridisch gevestigd vaderschap, dan moet met grote omzichtigheid worden nagegaan of dit vaderschap beschermenswaardig is. Enkel hier is een beoordeling in concreto mijns inziens verantwoord. Bezit van staat lijkt mij evenwel een ontoereikend instrument.

Indien stevig verankerd, mag de bestaande afstamming primeren. De Europese rechtspraak lijkt eveneens in die zin gevestigd. In het andere geval kan een ander het juridische vaderschap invullen. Ook indien er geen andere kandidaat is, moeten de rechten van de vader om een afstammingsband door te knippen evenwel gewaarborgd blijven.

Mogelijk staat het afschaffen van bijna elke toets aan het belang van het kind op gespannen voet met de Europese rechtspraak en de Grondwet. Echter, de toets aan het belang van het kind is niet consequent aanwezig in het Belgisch afstammingsrecht en bijgevolg discriminatoir. Zulks is mijns inziens evenmin in overeenstemming met de Grondwet en het EVRM.

Door het afschaffen van die toets worden vaders en kinderen meer gelijk voor de wet. Ook de machtspositie van de moeder wordt dan teruggeschroefd, waardoor een meer gelijke behandeling tussen vaders en moeders ontstaat.

Ik meen dat een belangenafweging zich pas moet situeren op het niveau van de gevolgen van die afstamming, in eerste instantie via een ouderlijk gezag op maat. Ouderlijk gezag is - in tegenstelling tot afstamming - moduleerbaar door de rechter én eindig. Het meerderjarige kind kan dan zelf beslissen welke banden het nog onderhoudt. 
De lege ferenda kan een uitbreiding van de gezagsrechten naar andere personen worden verdedigd, liefst naar Nederlands model. Het Engels model - meer dan twee ouders - is wat verregaand, maar kan in de toekomst misschien worden verkend.

Beslissingen inzake afstamming hoeven dus niet noodzakelijk te leiden tot een win-lose situatie. De juridische vader blijft principieel het beste af, maar ook de biologische of sociale vader gaat erop vooruit. Zoals hierboven aangehaald, moet het mogelijk zijn om beperktere versies van ouderlijke rechten toe te kennen aan zij die deze de facto (willen) uitoefenen. Daarnaast beschikken verwekker en sociale vader, met een bijzondere affectieve band de lege lata al over een recht op persoonlijk contact en informatie. De positie van de verwekker ter zake werd bijkomend door de Europese rechtspraak versterkt. De lege ferenda heb ik tot slot het invoeren van een verklaring van biologische vaderschap bepleit.

Conclusie? Er moet geëvolueerd worden naar een ouderschapsrecht, veeleer dan naar een allesbepalend afstammingsrecht. Biologische, sociale en juridische vader verdienen elk een rol in het leven van het kind. 


\section{- BIJLAGE -}

ARTIKELSGEWIJS OVERZICHT VAN DE ARRESTEN VAN HET GRONDWETTELIJK HOF ${ }^{312}$

\begin{tabular}{|c|c|c|c|c|c|}
\hline $\begin{array}{l}\text { Vermoeden } \\
\text { van } \\
\text { vaderschap }\end{array}$ & $\begin{array}{c}\text { Wetsartikel } \\
\text { BW }\end{array}$ & Wettelijke regel & $\begin{array}{c}\text { Titularis } \\
\text { vordering }\end{array}$ & Arrest & Schending? \\
\hline & \multirow[t]{3}{*}{$318, \S 1$} & \multirow[t]{3}{*}{$\begin{array}{l}\text { Betwisting vaderschap } \\
\text { echtgenoot met bezit van } \\
\text { staat: steeds onontvankelijk }\end{array}$} & Echtgenoot & $\begin{array}{c}\text { GwH } 3 \text { februari } \\
2011 \\
\text { Nr. 20/2011 }\end{array}$ & $\begin{array}{l}\text { Ja, art. } 22 \\
\text { Gw. } \\
\text { (in strijd met } \\
\text { art. } 8 \text { EVRM) }\end{array}$ \\
\hline & & & Verwekker & $\begin{array}{c}\text { GwH } 9 \text { juli } 2013 \\
\text { Nr. } 105 / 2013\end{array}$ & $\begin{array}{l}\text { Ja, art. } 22 \\
\text { Gw. } \\
\text { (in strijd met } \\
\text { art. } 8 \text { EVRM) }\end{array}$ \\
\hline & & & Kind & $\begin{array}{c}\text { GwH } 7 \\
\text { november } 2013 \\
\text { Nr. 147/2013 }\end{array}$ & $\begin{array}{l}\text { Ja, art. } 22 \\
\text { Gw. } \\
\text { (in strijd met } \\
\text { art. } 8 \text { EVRM) }\end{array}$ \\
\hline & \multirow[t]{5}{*}{$318, \S 2, \operatorname{lid} 1$} & \multirow[t]{5}{*}{$\begin{array}{l}\text { Betwisting vaderschap } \\
\text { echtgenoot na vervaltermijn: } \\
\text { steeds onontvankelijk }\end{array}$} & Echtgenoot & $\begin{array}{c}\text { GwH } 28 \text { maart } \\
2013 \\
\text { Nr. } 46 / 2013\end{array}$ & Neen \\
\hline & & & \multirow[t]{2}{*}{ Verwekker } & $\begin{array}{c}\text { GwH } 29 \text { januari } \\
2014 \\
\text { Nr. } 16 / 2014\end{array}$ & Neen \\
\hline & & & & $\begin{array}{c}\text { GwH } 9 \text { oktober } \\
2014 \\
\text { Nr. } 145 / 2014\end{array}$ & Neen \\
\hline & & & Kind & $\begin{array}{l}\text { GwH } 31 \text { mei } \\
2011 \\
\text { Nr. } 96 / 2011\end{array}$ & $\begin{array}{l}\text { Ja, artt. 10, } \\
11 \text { en } 22 \mathrm{Gw} \text {. } \\
\text { (in strijd met } \\
\text { art. } 8 j^{\circ} \text { art. } \\
14 \text { EVRM) }\end{array}$ \\
\hline & & & Moeder & $\begin{array}{c}\text { GwH } 20 \text { maart } \\
2014\end{array}$ & Neen \\
\hline
\end{tabular}

312 Geïnspireerd op Senaeve 2012b, p. 120 ; Senaeve 2013, pp. 187-188; Massager 2013, pp. 147-150; Swennen 2014, pp. 334-335. 


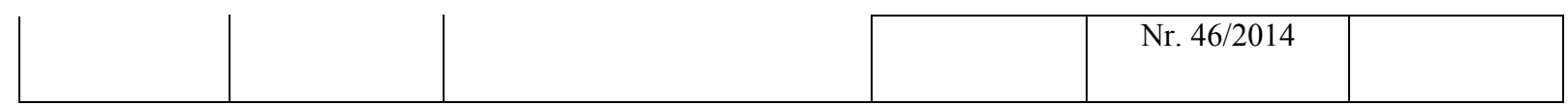

\begin{tabular}{|c|c|c|c|c|c|}
\hline Erkenning & $\begin{array}{c}\text { Wetsartikel } \\
\text { BW }\end{array}$ & Wettelijke regel & $\begin{array}{c}\text { Titularis } \\
\text { vordering }\end{array}$ & Arrest & Schending? \\
\hline & $\begin{array}{l}\text { 329bis, } \S 2, \\
\quad \operatorname{lid~} 2\end{array}$ & $\begin{array}{l}\text { Vaststelling vaderschap } \\
\text { 'erkenner' } \\
\text { bij toestemmingsweigering } \\
\text { moeder: } \\
\text { nooit rechterlijke toets aan } \\
\text { belang van het kind }<1 \text { jaar } \\
\text { indien biologische band }\end{array}$ & Verwekker & $\begin{array}{c}\text { GwH } 16 \\
\text { december } 2010 \\
\text { Nr. } 144 / 2010\end{array}$ & $\begin{array}{c}\mathrm{Ja} \text {, artt. } 10 \text { en } \\
11 \mathrm{Gw} .\end{array}$ \\
\hline & $\begin{array}{l}\text { 329bis, } \S 2, \\
\quad \text { lid } 3\end{array}$ & $\begin{array}{l}\text { Slechts marginale toetsing } \\
\text { van belang van het kind }(<1 \\
\text { jaar) indien biologische band }\end{array}$ & Verwekker & $\begin{array}{c}\text { GwH } 2 \text { juli } 2015 \\
\text { Nr. 101/2015 }\end{array}$ & $\begin{array}{c}\text { Ja, art. 22bis, } \\
\text { lid } 4 \text { Gw. }\end{array}$ \\
\hline & $\begin{array}{l}\text { 329bis, } \$ 2 \\
\quad \operatorname{lid~} 3\end{array}$ & $\begin{array}{l}\text { Slechts marginale toetsing } \\
\text { van belang van het kind }(<1 \\
\text { jaar) indien biologische band }\end{array}$ & Verwekker & $\begin{array}{c}\text { GwH } 2 \text { juli } 2015 \\
\text { Nr. 102/2015 }\end{array}$ & $\begin{array}{c}\text { Ja, art. 22bis, } \\
\text { lid } 4 \text { Gw. }\end{array}$ \\
\hline & \multirow[t]{5}{*}{$330, \S 1, \operatorname{lid} 1$} & \multirow[t]{5}{*}{$\begin{array}{l}\text { Betwisting vaderschap } \\
\text { 'erkenner' met bezit van staat: } \\
\text { steeds onontvankelijk }\end{array}$} & \multirow[t]{2}{*}{ Verwekker } & $\begin{array}{l}\text { GwH } 7 \text { maart } \\
2013 \\
\text { Nr. } 29 / 2013\end{array}$ & $\begin{array}{l}\text { Ja, art. } 22 \\
\text { Gw. } \\
\text { (in strijd met } \\
\text { art. } 8 \text { EVRM) }\end{array}$ \\
\hline & & & & $\begin{array}{c}\text { GwH } 9 \text { juli } 2013 \\
\text { Nr. } 96 / 2013\end{array}$ & $\begin{array}{l}\text { Ja, art. } 22 \\
\text { Gw. } \\
\text { (in strijd met } \\
\text { art. } 8 \text { EVRM) }\end{array}$ \\
\hline & & & \multirow[t]{3}{*}{ 'Erkenner' } & $\begin{array}{c}\text { GwH } 19 \\
\text { september } 2014 \\
\text { Nr. 127/2014 }\end{array}$ & $\begin{array}{l}\text { Ja, art. } 22 \\
\text { Gw. } \\
\text { (in strijd met } \\
\text { art. } 8 \text { EVRM) }\end{array}$ \\
\hline & & & & $\begin{array}{c}\text { GwH } 25 \\
\text { september } 2014 \\
\text { Nr. 139/2014 }\end{array}$ & $\begin{array}{l}\text { Ja, art. } 22 \\
\text { Gw. } \\
\text { (in strijd met } \\
\text { art. } 8 \text { EVRM) }\end{array}$ \\
\hline & & & & $\begin{array}{c}\text { GwH } 12 \text { maart } \\
2015 \\
\text { Nr. } 35 / 2015\end{array}$ & $\begin{array}{l}\text { Ja, art. } 22 \\
\text { Gw. } \\
\text { (in strijd met } \\
\text { art. } 8 \text { EVRM) }\end{array}$ \\
\hline
\end{tabular}




\begin{tabular}{|c|c|c|c|c|}
\hline \multirow[t]{3}{*}{$330, \S 1$, lid 2} & \multirow[t]{3}{*}{$\begin{array}{l}\text { Betwisting vaderschap: } \\
\text { 'erkenner' moet steeds } \\
\text { bewijzen dat toestemming } \\
\text { gebrekkig was }\end{array}$} & \multirow[t]{2}{*}{ 'Erkenner' } & $\begin{array}{c}\text { GwH } 25 \\
\text { september } 2014 \\
\text { Nr. } 139 / 2014\end{array}$ & Neen \\
\hline & & & $\begin{array}{c}\text { GwH } 19 \\
\text { maart } 2015 \\
\text { Nr. } 38 / 2015\end{array}$ & Neen \\
\hline & & Moeder & $\begin{array}{c}\text { GwH } 24 \\
\text { september } 2015 \\
\text { Nr. } 126 / 2015\end{array}$ & Neen \\
\hline \multirow[t]{5}{*}{$330, \S 1$, lid 4} & \multirow[t]{3}{*}{$\begin{array}{l}\text { Betwisting vaderschap } \\
\text { 'erkenner' na vervaltermijn: } \\
\text { steeds onontvankelijk }\end{array}$} & \multirow[t]{2}{*}{ Verwekker } & $\begin{array}{c}\text { GwH } 17 \text { oktober } \\
2013 \\
\text { Nr. } 139 / 2013\end{array}$ & Neen \\
\hline & & & $\begin{array}{c}\text { GwH } 5 \text { december } \\
2013 \\
\text { Nr. } 165 / 2013\end{array}$ & Neen \\
\hline & & 'Erkenner' & $\begin{array}{c}\text { GwH } 25 \\
\text { september } 2014 \\
\text { Nr. } 139 / 2014\end{array}$ & Neen \\
\hline & $\begin{array}{c}\text { Betwisting vaderschap: } \\
\text { aanvang termijn } 1 \text { jaar steeds } \\
\text { vanaf kennis biologische } \\
\text { werkelijkheid } \\
\text { (ook indien erkenning later } \\
\text { plaatsvindt) }\end{array}$ & Verwekker & $\begin{array}{l}\text { GwH } 6 \text { april } \\
2011 \\
\text { Nr. 54/2011 }\end{array}$ & $\begin{array}{c}\text { Ja, artt. } 10 \text { en } \\
11 \mathrm{Gw} .\end{array}$ \\
\hline & $\begin{array}{c}\text { Betwisting vaderschap: } \\
\text { aanvang termijn } 1 \text { jaar steeds } \\
\text { vanaf kennis biologische } \\
\text { werkelijkheid } \\
\text { (ook indien geen kennis van } \\
\text { erkenning) }\end{array}$ & Verwekker & $\begin{array}{c}\text { GwH } 5 \text { december } \\
2013 \\
\text { Nr. } 165 / 2013\end{array}$ & $\begin{array}{c}\text { Ja, artt. } 10 \text { en } \\
11 \mathrm{Gw} .\end{array}$ \\
\hline
\end{tabular}




\begin{tabular}{|c|c|c|c|c|c|}
\hline $\begin{array}{l}\text { Onderzoek } \\
\text { naar } \\
\text { vaderschap }\end{array}$ & $\begin{array}{c}\text { Wetsartikel } \\
\text { BW }\end{array}$ & Wettelijke regel & $\begin{array}{c}\text { Titularis } \\
\text { vordering }\end{array}$ & Arrest & Schending? \\
\hline & 325 & $\begin{array}{l}\text { Incestverbod verhindert } \\
\text { onderzoek naar vaderschap } \\
\text { (dubbelzijdige vestiging } \\
\text { afstamming): steeds } \\
\text { onontvankelijk }\end{array}$ & Moeder & $\begin{array}{c}\text { GwH } 9 \text { augustus } \\
2012 \\
\text { Nr. 103/2012 }\end{array}$ & $\begin{array}{c}\text { Ja, artt. } 10 \text { en } \\
11 \mathrm{Gw} .\end{array}$ \\
\hline & \multirow[t]{2}{*}{$\begin{array}{l}\text { 332quinquie } \\
\text { s, } § 2, \text { lid } 1\end{array}$} & $\begin{array}{l}\text { Bij verzet moeder: nooit } \\
\text { rechterlijke toets aan belang } \\
\text { van het kind }<1 \text { jaar indien } \\
\text { biologische band }\end{array}$ & Verwekker & $\begin{array}{c}\text { GwH } 3 \text { mei } 2012 \\
\text { Nr. } 61 / 2012\end{array}$ & $\begin{array}{c}\text { Ja, artt. } 10 \text { en } \\
11 \mathrm{Gw} .\end{array}$ \\
\hline & & $\begin{array}{l}\text { Slechts marginale toetsing } \\
\text { van belang van het kind }(<1 \\
\text { jaar) indien biologische band }\end{array}$ & Verwekker & $\begin{array}{c}\text { GwH } 7 \text { maart } \\
2013 \\
\text { Nr. } 30 / 2013\end{array}$ & $\begin{array}{c}\text { Ja, art. 22bis, } \\
\text { lid } 4 \mathrm{Gw} .\end{array}$ \\
\hline & $\begin{array}{c}322 \text { en } \\
\text { 332quinquie } \\
\text { s }\end{array}$ & $\begin{array}{c}\text { Enkel rechterlijke toets aan } \\
\text { belang van het kind ( }<1 \text { jaar), } \\
\text { niet aan belangen van } \\
\text { anderen, indien biologische } \\
\text { band }\end{array}$ & Kind & $\begin{array}{c}\text { GwH } 20 \text { maart } \\
2014 \\
\text { Nr. } 48 / 2014\end{array}$ & Neen \\
\hline
\end{tabular}




\section{- BIBLIOGRAFIE -}

\section{RECHTSLEER}

\section{Adams 2008}

M. Adams, Verantwoordelijkheid en recht, Mechelen: Kluwer 2008, 534 p.

\section{Antokolskaia, Schrama, Boele-Woelki e.a. 2014}

M.V. Antokolskaia, W.M. Schrama, K.R.S.D. Boele-Woelki, C.C.J.H. Bijleveld, C.G. Jeppesen de Boer \& G. van Rossum, Meeroudergezag: een oplossing voor kinderen met meer dan twee ouders? Een empirisch en rechtsvergelijkend onderzoek, Den Haag: Boom Juridische uitgevers 2014, $240 \mathrm{p}$.

\section{Antokolskaia \& Verschelden 2012}

M.V. Antokolskaia \& G. Verschelden, 'Kinderen: gezag, verblijf en alimentatie naar Nederlands en Belgisch recht', in: K. Boele-Woelki \& F. Swennen (red.), Vergelijkenderwijs: Actuele ontwikkelingen in het Belgische en Nederlandse familierecht, Den Haag: Boom Juridische uitgevers 2012, pp. 163-227.

\section{Audoore 2012}

S. Audoore, 'Overzicht van rechtspraak (2003-2011) - De uitoefening van het ouderlijk gezag', T.Fam. 2012, afl. 3, pp. 55-72.

\section{Barbaix 2009}

R. Barbaix, 'Koekoekskinderen in het familiaal vermogensrecht', in: R. Barbaix, S. Eggermont, N. Geelhand \& F. Swennen (red.), Handboek Estate Planning, Bijzonder deel 2. Koekoekskinderen, Brussel: Larcier 2009, pp. 37-109.

\section{Bereswill, Scheiwe \& Wolde 2006}

M. Bereswill, K. Scheiwe \& A. Wolde, 'Einleitung', in: M. Bereswill, K. Scheiwe \& A. Wolde (red.), Vaterschaft im Wandel: Multidisziplinäre Analysen und Perspektiven aus geschlechtertheoretischer Sicht, Weinheim und München: Juventa 2006, p. 8.

\section{Broeckx, Laenens, Scheers e.a. 2008}

K. Broeckx, J. Laenens, D. Scheers, \& P. Thiriar, Handboek gerechtelijk recht, Antwerpen: Intersentia 2008, 814 p.

\section{Brouwers 2009}

S. Brouwers, 'Alimentatie', in: Algemene praktische rechtsverzameling, Mechelen: Kluwer 2009. 


\section{Brouwers 2012}

S. Brouwers, 'De bijzondere ouderlijke onderhoudsverplichtingen', TPR 2012, afl. 4, pp. 1860-1944.

\section{Brouwers 2013}

S. Brouwers, Kinderalimentatie: en wat met het bedrag?, Brussel: Larcier 2013, 134 p.

\section{Casman 2008}

H. Casman, 'Actueel Belgisch afstammingsrecht in vogelvlucht', NFM 2008, afl. 4, pp. 119130.

\section{De Maeyer \& Vergauwen 2009}

E. De Maeyer \& C. Vergauwen, 'Een recht op persoonlijk contact voor derden: de notie "bijzondere affectieve band" nader onderzocht' (noot onder Cass. 16 januari 2009), RABG 2009, afl. 12, pp. 863-865.

\section{De Maeyer \& Vergauwen 2011}

E. De Maeyer \& C. Vergauwen, 'Het belang van het kind versus de biologische werkelijkheid: het blijft een moeilijk vraagstuk' (noot onder GwH 16 december 2010), RABG 2011, afl. 13, pp. 887-889.

\section{Demaret 2013}

M. Demaret, 'L'intérêt de l'enfant: Veni, vidi, vici...' (noot onder GwH 7 maart 2013), RTDF 2013, afl. 3, pp. 800-810.

\section{Gallus 2011}

N. Gallus, 'Filiation paternelle dans le mariage: le droit de contestation du mari et l'intérêt de l'enfant selon la Cour constitutionnelle' (noot onder GwH 3 februari 2011), Acr.dr.fam. 2011, afl. 3-4, pp. 77-79.

\section{Gallus 2013a}

N. Gallus, 'Le droit de la filiation 'déconstruit' par la Cour constitutionnelle', JLMB 2013, afl. 26, pp. 1352-1368.

\section{Gallus 2013b}

N. Gallus, 'Lorsque la Cour constitutionnelle s'arroge le pouvoir de reconstruire le droit de la filiation’ (noot onder GwH 7 maart 2013), Act.dr.fam. 2013, afl. 5, pp. 79-81.

\section{Gallus \& Van Gysel 2013}

N. Gallus \& A. Van Gysel, 'Les décisions récentes de la Cour constitutionnelle en matière de filiation: humanisme ou aberration?', Rev.not.b. 2013, afl. 3075, pp. 374-405. 


\section{Gerlo 2002}

J. Gerlo, 'Ons afstammingsrecht moet (meer) aansluiten bij de biologische afstamming. Bedenkingen rond afstamming, adoptie en ouderlijk gezag.', in: W. Debeuckelaere, J. Meeusen \& H. Willekens (red.), Met rede omkleed, de rede ontkleed. Opstellen aangeboden aan Fons Heyvaert, Gent: Mys \& Breesch 2002, pp. 101-115.

\section{Gevers \& Godfroid 2013}

S. Gevers \& A. Godfroid, 'Grondwetsbepaling rechten van kind geen directe werking', Juristenkrant 2013, afl. 273, p. 5.

\section{Harris \& Butterworth 2002}

M. Harris \& G. Butterworth, Developmental psychology, Hove: Psychology Press 2002, 371 p.

\section{Heyvaert 1979}

A. Heyvaert, 'Het wezen van de instituten afstamming en huwelijk', RW 1979/80, (738).

\section{Ignovska \& Verschelden 2013}

E. Ignovska \& G. Verschelden, 'De rechterlijke toetsing van het belang van het kind bij het onderzoek naar het vaderschap' (noot onder GwH 7 maart 2013), TJK 2013, afl. 2, pp. 155164.

\section{Kind en Gezin 2013}

Kind en Gezin, Het kind in Vlaanderen 2013, www.kindengezin.be/img/kind-in-Vlaanderen2013.pdf.

\section{Lambersy \& Vergauwen 2013}

B. Lambersy \& C. Vergauwen, 'De vervaltermijn voor het instellen van de vordering van de echtgenoot van de moeder tot betwisting van het vermoeden van vaderschap versus het recht op eerbiediging van het privé - en gezinsleven: een gevoelige afweging' (noot onder GwH 28 maart 2013), RABG 2013, afl. 13, pp. 912-915.

\section{Leleu 2013}

Y.-H. Leleu, 'Propos Introductifs. A l'orée d'un droit judiciaire des familles', in: Y.-H. Leleu \& D. Pire (red.), Actualités de droit des personnes et des familles, Brussel: Larcier 2013, pp. 9-19.

\section{Leleu \& Sauveur 2013}

Y.-H. Leleu \& L. Sauveur, 'La filiation incestueuse et la Cour constitutionnelle', RTDF 2013, afl. 1, pp. 213-228. 


\section{Martens 2007}

I. Martens, 'Het verblijfsco-ouderschap als prioritair te onderzoeken verblijfsregeling', in: P. Senaeve, F. Swennen \& G. Verschelden (red.), Verblijfsco-ouderschap. Uitvoering en sanctionering van verblijfs- en omgangsregelingen, Antwerpen: Intersentia 2007, pp. 1-38.

\section{Massager 2011}

N. Massager, 'La prophétie de Gerlo - Réflexion à propos des derniers arrêts de la Cour constitutionnelle en matière de filiation', Act.dr.fam. 2011, afl. 7, pp. 130-139.

\section{Massager 2013}

N. Massager, 'La Cour constitutionelle et le droit de la filiation: Mémento à l'usage des praticiens', Act.dr.fam. 2013, afl. 7, pp. 147-150.

\section{Mathieu \& Rasson 2012}

G. Mathieu \& A-C. Rasson, 'L'interdit de l'inceste : une norme symbolique évanescente?', JDJ 2012, afl. 319, pp. 23-34.

\section{Melkebeek 2012}

C. Melkebeek, 'Waar zit het verschil in belang tussen een kind van 364 dagen en een kind van 366 dagen oud?', TJK 2012, afl. 2, pp. 140-142.

\section{Meulders-Klein 2008}

M.-T. Meulders-Klein, 'The position of the father in European legislation', in: A. Bainham (red.), Parents and Children, Aldershot: Ashgate 2008, pp. 3-25.

\section{Mortelmans, Van Ourti \& Verstreken 2002}

D. Mortelmans, S. Van Ourti \& M. Verstreken, 'De transformatie van een man in een vader. De gevolgen van een eerste kind op het leven van een man', in: Hoger Instituut voor Gezinswetenschappen, Vaders in soorten, Tielt: Lannoo 2002, pp. 47-72.

\section{Poelman \& Kruythooft 2010}

M. Poelman \& M. Kruythooft, Verblijfsco-ouderschap en de loopbaan van de ouders vanuit een genderperspectief, Antwerpen: Steunpunt Gelijkekansenbeleid 2010, 104 p.

\section{Quirynen 2011a}

A. Quirynen, 'Een andere (grondwetsconforme?) kijk op bezit van staat' (noot onder GwH 7 juli 2011), T.Fam. 2011, afl. 7, pp. 154-161.

\section{Quirynen 2011b}

A. Quirynen, 'De (on)verenigbaarheid van de (strikte) vervaltermijn voor de betwisting van het vaderschap van de echtgenoot met het recht op eerbiediging van het privéleven' (noot onder GwH 31 mei 2011), T.Fam. 2011, afl. 9, pp. 218-223. 


\section{Quirynen 2014}

A. Quirynen, 'De (on)grondwettelijkheid van de vervaltermijn tot betwisting van het juridische vaderschap', T.Fam. 2014, afl. 2, pp. 42-50.

\section{Rasson-Roland \& Sosson 2011}

A. Rasson-Roland \& J. Sosson, 'Coups de tonnerre constitutionnels dans la filiation: l'article 318 du Code civil dans la tourmente...', RTDF 2011, afl. 3, pp. 581-613.

\section{Schwenzer 2007}

I. Schwenzer, 'Introduction', in: I. Schwenzer (red.), Tensions between legal, biological and social concepts of parentage, Antwerpen-Oxford: Intersentia 2007, pp. 1-26.

\section{Senaeve 1989/90}

P. Senaeve, 'Vader, moeder of het O.C.M.W.? Familierechtelijke aspecten van het recht op onderwijs', Jura Falconis 1989/90, pp. 475-503.

\section{Senaeve 2011}

P. Senaeve, 'Kan er inzake afstamming nog zinvol wetgevend werk verricht worden?', T.Fam. 2011, afl. 8, pp. 170-171.

\section{Senaeve 2012a}

P. Senaeve, 'Rechterlijke censurering van wetgeving op het vlak van het familierecht op grond van de bescherming van de mensenrechten - Twintig jaar later', in: C. Declerck, T. Helms, J.M. Scherpe, P. Senaeve \& A.-L. Verbeke (red.), Confronting the Frontiers of Family and Succession Law, Antwerpen: Intersentia 2012, pp. 1299-1318.

\section{Senaeve 2012b}

P. Senaeve, 'Synoptische tabel aangaande de arresten van en de prejudiciële vragen aan het Grondwettelijk Hof inzake afstamming’, T.Fam. 2012, afl. 4-5, p. 120.

\section{Senaeve 2013}

P. Senaeve, 'Synoptische tabel aangaande de arresten van en de prejudiciële vragen aan het Grondwettelijk Hof inzake afstamming (vervolg)', T.Fam. 2013, afl. 7, pp. 187-188.

\section{Sosson 2013a}

J. Sosson, 'Cour constitutionnelle, filiation et intérêt de l'enfant. “C'est quand qu'on va où ?"”, in: Y.-H. Leleu \& D. Pire (red.), Actualités de droit des personnes et des familles, Brussel: Larcier 2013, pp. 97-123.

\section{Sosson 2013b}

J. Sosson, 'Actions en contstation de paternité: La Cour constitutionnelle ne souffle-t-elle pas le chaud et le froid?' (noot onder GwH 28 maart 2013), Rev.Trim.dr.Fam. 2013, afl. 2, pp. 543-556. 


\section{Stevens 2001}

L. Stevens, 'Leeftijd kind niet relevant bij belangenafweging erkenning', Juristenkrant 2001, nr. 223, pp. 4-5.

\section{Swennen 2007}

F. Swennen, 'Het onderzoek naar het moederschap en naar het vaderschap', in P. Senaeve, F. Swennen \& G. Verschelden (red.), De hervorming van het afstammingsrecht, Antwerpen: Intersentia 2007, pp. 219-258.

\section{Swennen 2008}

F. Swennen, Familierecht in kort bestek, Antwerpen: Intersentia 2008, 291 p.

\section{Swennen 2010}

F. Swennen, 'Alimentatie voor kinderen: een overzicht', in: CBR (red.), Alimentatie \& Kinderen, Antwerpen: Intersentia 2010, pp. 19-54.

\section{Swennen 2011a/12}

F. Swennen, 'Privéleven is personenrecht is familierecht', RW 2011/12, nr. 1, pp. 41-48.

\section{Swennen 2011b/12}

F. Swennen, 'Afstamming en Grondwettelijk Hof', RW 2011/12, nr. 25, pp. 1102-1110.

\section{Swennen 2011c}

F. Swennen, 'De toets aan het belang van het kind van de vaderlijke erkenning' (noot onder GwH 16 december 2010), T.Fam. 2011, afl. 4, pp. 57-61.

\section{Swennen 2013a}

F. Swennen, 'Afstammingsvorderingen en het belang van het kind tijdens het eerste levensjaar' (noot onder GwH 3 mei 2012), T.Fam. 2013, afl. 3-4, pp. 92-93.

\section{Swennen 2013b}

F. Swennen, 'Kinderen krijgen (soms) voorrang in het afstammingsrecht'(noot onder GwH 7 maart 2013), T. Fam. 2013, afl. 9, pp. 235-236.

\section{Swennen 2013c}

F. Swennen, 'Rechten van niet-ouders met betrekking tot minderjarigen', in: P. Senaeve, F. Swennen \& G. Verschelden (red.), Ouders en kinderen, Antwerpen: Intersentia 2013, pp. 257309.

\section{Swennen 2014}

F. Swennen, Het personen- en familierecht, Antwerpen: Intersentia 2014, 582 p. 


\section{Swennen \& Eggermont 2009}

F. Swennen \& S. Eggermont, 'Koekoekskinderen in het familierecht', in: R. Barbaix, S. Eggermont, N. Geelhand \& F. Swennen (red.), Handboek estate planning. Bijzonder deel 2. Koekoekskinderen, Brussel: Larcier 2009, pp. 1-36.

\section{Van Crombrugge 2005}

H. Van Crombrugge, 'Geen opvoeding zonder uitgesproken engagement. Van huwelijksbelofte naar opvoedingscontract', in: H. Van Crombrugge \& E. Lombaert (red.), Gezin en opvoeding: weldadig en gewelddadig, Antwerpen: Garant 2005, pp. 77-99.

\section{Vergauwen 2013}

C. Vergauwen, 'De vaststelling van een juridische afstammingsband versus de uitoefening van de rechten die daaruit voortvloeien', RAGB 2013, afl. 5, pp. 244-245.

\section{Verhoeven 2011}

M. Verhoeven, 'Termijn betwisting vaderschapsvermoeden is discriminerend', Juristenkrant 2011, nr. 231, pp. 4-5.

\section{Verschelden 2005a}

G. Verschelden, Origineel ouderschap herdacht. Pleidooi voor een globale hervorming van het afstammingsrecht, Brugge: Die Keure 2005, 422 p.

\section{Verschelden 2005b}

G. Verschelden, 'Het belang van het kind in het afstammingsrecht', TJK 2005, afl. 4, pp. 168181.

\section{Verschelden 2007a}

G. Verschelden, 'De moederlijke en de vaderlijke erkenning', in: P. Senaeve, F. Swennen \& G. Verschelden (red.), De hervorming van het afstammingsrecht, Antwerpen: Intersentia 2007, pp. 87-218.

\section{Verschelden 2007b}

G. Verschelden, 'Filiation, adoption, autorité parentale et le droit aux relations personnelles en Belgique anno 2007', in: I. Schwenzer (red.), Tensions Between Legal, Biological and Social Conceptions of Parentage, Antwerpen: Intersentia 2007, pp. 53-89.

\section{Verschelden 2007c/08}

G. Verschelden, 'Het hervormde afstammingsrecht: een nieuw compromis tussen biologisch en sociaal ouderschap', RW 2007/08, nr. 9, pp. 338-358.

\section{Verschelden 2011}

G. Verschelden, 'Het vertrekpunt van de vervaltermijn waarbinnen de beweerde biologische vader een vaderlijke erkenning moet betwisten' (noot onder GwH 6 april 2011), T.Fam. 2011, afl. 5, pp. 96-100. 


\section{Verschelden 2013a}

G. Verschelden, 'De hervorming van het afstammingsrecht door het Grondwettelijk Hof', in: P. Senaeve, F. Swennen \& G. Verschelden (red.), Ouders en kinderen, Antwerpen: Intersentia 2013, pp. 1-70.

\section{Verschelden 2013b}

G. Verschelden, 'Het belang van het kind in het komende afstammingsrecht: considerans voor de wetgever, niet voor de rechter', T.Fam. 2013, afl. 5, pp. 98-99.

\section{Verschelden 2013c}

G. Verschelden, 'Bezit van staat steeds meer onder vuur', Juristenkrant 2013, nr. 266, pp. 1, 4-5.

\section{Verschelden 2013d}

G. Verschelden, 'Volle toetsing van belang kind noodzakelijk bij vaderschapsonderzoek', Juristenkrant 2013, afl. 267, pp. 4-5.

\section{Vonk 2013}

M. Vonk, 'Weten, kennen er erkennen: kinderen van ouders die niet samen zijn', NTM/NJCM-Bull. 2013, afl. 4, pp. 515-531.

\section{Willekens 2006}

H. Willekens, 'Vaterschaft als Institution', in: M. Bereswill, K. Scheiwe \& A. Wolde (red.), Vaterschaft im Wandel: Multidisziplinäre Analysen und Perspektiven aus geschlechtertheoretischer Sicht, Weinheim und München: Juventa 2006, pp. 19-35.

\section{Wuyts 2011}

T. Wuyts, 'Het bezit van staat als absolute grond van niet-ontvankelijkheid bij betwisting van de afstamming strijdig met het recht op eerbiediging van het privéleven' (noot onder GwH 3 februari 2011), T.Fam. 2011, afl. 4, pp. 64-74.

\section{Wuyts 2012a}

T. Wuyts, 'Ouderlijk gezag moet op maat van het gezin georganiseerd worden', Juristenkrant 2012, afl. 253, p. 14.

\section{Wuyts 2012b}

T. Wuyts, 'Het verbod tot vaststelling van een afstammingsband ingeval daaruit incest blijkt strijdig bevonden met het gelijkheidsbeginsel' (noot onder GwH 9 augustus 2012), T.Fam. 2012, afl. 10, pp. 221-226.

\section{Wuyts 2013}

T. Wuyts, Ouderlijk gezag: een coherente gezagsregeling voor minderjarigen, Antwerpen: Intersentia 2013, $990 \mathrm{p}$. 


\section{RECHTSPRAAK EHRM}

EHRM 21 november 1984, 8777/79 (Rasmussen /Denemarken).

EHRM 27 oktober 1994, 18535/91 (Kroon e.a./Nederland).

EHRM 29 juni 1999, 27110/95 (Nylund/Finland).

EHRM 7 februari 2002, 53176/99 (Mikulic/Kroatië).

EHRM 5 november 2002, 33711/96 (Yousef/Nederland).

EHRM 26 juni 2003, 48206/99 (Maire /Portugal).

EHRM 8 juli 2003, 31871/96 (Sommerfeld/Duitsland).

EHRM 26 februari 2004, 74969/01 (Görgülü/Duitsland).

EHRM 1 juni 2004, 45582/99 (Lebbink /Nederland).

EHRM 22 juni 2004, 78028/01 en 78030/01 (Pini e.a./Roemenië).

EHRM 24 november 2005, 74820/01 (Shofman/Rusland).

EHRM 12 januari 2006, 26111/02 (Mizzi/Malta).

EHRM 18 mei 2006, 55339/00 (Rozanski/Polen).

EHRM 10 oktober 2006, 10699/05 (Paulik/Slovakije).

EHRM 9 november 2006, 11449/02 (Tavli/Turkije).

EHRM 28 juni 2007, 76240/01 (Wagner en J.M.W.L/Luxemburg).

EHRM 20 december 2007, 23890/02 (Phinikaridou/Cyprus).

EHRM 9 maart 2010, 35016/07 (Wulff/Denemarken).

EHRM 6 juni 2010, 41615/07 (Neulinger en Shuruk/Zwitserland).

EHRM 6 juli 2010, 17038/04 (Grönmark/Finland).

EHRM 6 juli 2010, 36498/05 (Backlund/Finland).

EHRM 21 december 2010, 20578/07 (Anayo/Duitsland).

EHRM 15 september 2011, 17080/07 (Schneider/Duitsland).

EHRM 22 maart 2012, 23338/09 (Kautzor/Duitsland).

EHRM 22 maart 2012, 45071/09 (Ahrens/Duitsland).

EHRM 12 april 2012, 43547/08 (Stübing/Duitsland).

EHRM 17 april 2012, 805/09 (Pascal/Roemenië).

EHRM 15 januari 2013, 7361/05 (Laakso/Finland).

EHRM 29 januari 2013, 13072/05 (Röman/Finland).

EHRM 26 november 2013, 27853/09 (X/Letland).

EHRM 18 februari 2014, 28609/08 (A.L./Polen).

\section{RECHTSPRAAK GRONDWETTELIJK HOF}

GwH 12 mei 2004, nr.79/2004, JLMB 2004, afl. 38, 1660, m.nt. van N. Banneux; NJW 2004, afl. 88, 1202, m.nt. van G. Verschelden; $R W$ 2004-05, afl. 7, 256; RTDF 2004, afl. 3, 651; TJK 2005, afl. 2, 94, m.nt. van S. Brouwers.

GwH 16 december 2010, nr. 144/2010, Act.dr.fam. 2011, 2, m.nt. van N. Massager; RABG 2011, 833, m.nt. van E. De Maeyer en C. Vergauwen; T. Fam. 2011, 56, m.nt. van F. Swennen.

GwH 3 februari 2011, nr. 20/2011, Act.dr.fam. 2011, 75, m.nt. van N. Gallus; T. Fam. 2011, 61 , m.nt. van T. Wuyts. 
GwH 6 april 2011, nr. 54/2011, Act.dr.fam. 2011, 146, m.nt. van N. Massager; T. Fam. 2011, 93, m.nt. van G. Verschelden.

GwH 31 mei 2011, nr. 96/2011, Act.dr.fam. 2011, 142, m.nt. van N. Massager; RW 2010-11, 1791, m.nt. van F. Swennen; T. Fam. 2011, 214, m.nt. van A. Quirynen.

GwH 7 juli 2011, nr. 122/2011, Act.dr.fam. 2011, afl. 7, 140, m.nt. van N. Massager; $R W$ 2011-2012, nr. 25, 1118, m.nt. van F. Swennen.

GwH 3 mei 2012, nr. 61/2012, T. Fam. 2013, 90, m.nt. van F. Swennen.

GwH 9 augustus 2012, nr. 103/2012, Act.dr.fam. 2012, 150, m.nt. van A.-C. Van Gysel; JDJ 2012, 35, m.nt. van G. Mathieu en A. Rasson; JLMB 2011, 1281, m.nt. van P. Martens; RTDF 2013, 204, m.nt. van Y.-H. Leleu en R. Sauveur; T. Fam. 2012, m.nt. van T. Wuyts.

GwH 7 maart 2013, nr. 29/2013, Act.dr.fam. 2013, 73, m.nt. van N. Gallus; RTDF 2013, 557, m.nt. J. Sosson; T. Fam. 2013, 216, m.nt. van T. Wuyts.

GwH 7 maart 2013, nr. 30/2013, Act.dr.fam. 2013, 76, m.nt. van N. Gallus; RTDF 2013, 789, m.nt. van M. Demaret; T. Fam. 2013, 232, m.nt. van F. Swennen; TJK 2013, 151, m.nt. van E. Ignovska en G. Verschelden.

GwH 28 maart 2013, nr. 46/2013, RABG 2013, 903, m.nt. van B. Lambersy, en C. Vergauwen; RTDF 2013, 535, m.nt. van J. Sosson.

GwH 9 juli 2013, nr. 105/2013, JLMB 2013, 1349, m.nt. van N. Gallus; T. Fam. 2013, 220, m.nt. van T. Wuyts.

GwH 9 juli 2013, nr. 96/2013, JLMB 2013, 1344, m.nt. van N. Gallus; T. Fam. 2013, 218, m.nt. van T. Wuyts.

GwH 17 oktober 2013, nr. 139/2013, Act.dr.fam. 2014, afl. 3, 71; RTDF 2013, afl. 4, 1045, m.nt. van G. Mathieu.

GwH 7 november 2013, nr. 147/2013, Act.dr.fam. 2014, afl. 3, 66; RTDF 2014, afl. 2, 385; RW 2013-14, afl. 17, 679.

GwH 5 december 2013, nr. 165/2013, Act.dr fam. 2014, afl. 3, 62; T. Fam. 2014, afl.2, 39, m.nt. van A. Quirynen.

GwH 29 januari 2014, nr. 16/2014, Act.dr.fam. 2014, afl. 3, 59.

GwH 20 maart 2014, nr. 46/2014, RTDF 2014, afl. 2, 388; RW 2013-14, nr. 33, 1320.

GwH 20 maart 2014, nr. 48/2014, RTDF 2014, afl. 2, 389; RW 2013-14, nr. 33, 1320.

GwH 19 september 2014, nr. 127/2014, RW 2014-15 (samenvatting), afl. 7, 279 en http://www.rw.be/.

GwH 25 september 2014, nr. 139/2014, RW 2014-15 (samenvatting), afl. 7, 279 en http://www.rw.be/.

GwH 9 oktober 2014, nr. 145/2014, http://www.const-court.be.

GwH 12 maart 2015, nr. 35/2014, http://www.const-court.be.

GwH 19 maart 2015, nr. 38/2015, http://www.const-court.be.

GwH 2 juli 2015, nr. 101/2015, http://www.const-court.be.

GwH 2 juli 2015, nr. 102/2015, http://www.const-court.be.

GwH 24 september 2015, nr. 126/2015, http://www.const-court.be. 